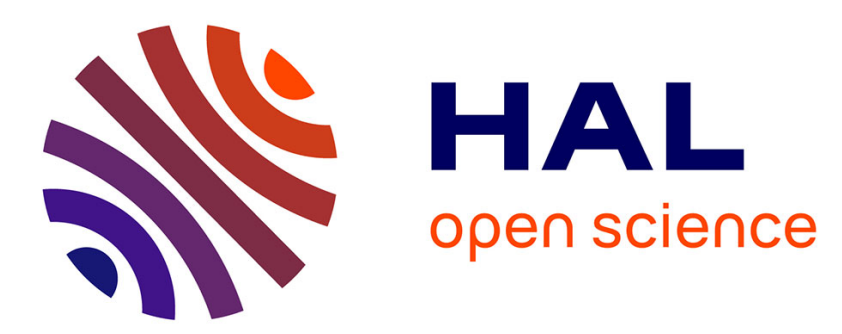

\title{
Residential Solid Oxide Fuel Cell Generator Fuelled by Ethanol: Cell, Stack, and System Modelling with a Preliminary Experiment
}

\author{
Andrea Lanzini, Massimo Santarelli, Gianmichele Orsello
}

\section{To cite this version:}

Andrea Lanzini, Massimo Santarelli, Gianmichele Orsello. Residential Solid Oxide Fuel Cell Generator Fuelled by Ethanol: Cell, Stack, and System Modelling with a Preliminary Experiment. Fuel Cells, 2010, 10 (4), pp.654. 10.1002/fuce.201000004 . hal-00552373

HAL Id: hal-00552373

https://hal.science/hal-00552373

Submitted on 6 Jan 2011

HAL is a multi-disciplinary open access archive for the deposit and dissemination of scientific research documents, whether they are published or not. The documents may come from teaching and research institutions in France or abroad, or from public or private research centers.
L'archive ouverte pluridisciplinaire HAL, est destinée au dépôt et à la diffusion de documents scientifiques de niveau recherche, publiés ou non, émanant des établissements d'enseignement et de recherche français ou étrangers, des laboratoires publics ou privés. 


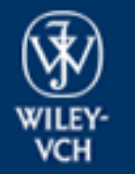

Fuel Cells

VCH

\section{Residential Solid Oxide Fuel Cell Generator Fuelled by Ethanol: Cell, Stack, and System Modelling with a Preliminary Experiment}

\begin{tabular}{|r|l|}
\hline Journal: & Fuel Cells \\
\hline Manuscript ID: & fuce.201000004.R1 \\
\hline Wiley - Manuscript type: & Original Research Paper \\
\hline Date Submitted by the \\
Author: & $30-$ Mar-2010 \\
\hline Complete List of Authors: & $\begin{array}{l}\text { Lanzini, Andrea; Politecnico di Torino, Energetics } \\
\text { Santarelli, Massimo; Politecnico di Torino, Energetics } \\
\text { Orsello, Gianmichele; Turbocare Spa }\end{array}$ \\
\hline \hline Keywords: & Ejector, Ethanol, Recirculation, Tubular, System Modelling \\
\hline
\end{tabular}

\section{S ScholarONE" \\ Manuscript Central}


1

2

3

\title{
Residential Solid Oxide Fuel Cell Generator Fuelled by Ethanol: Cell, Stack, and System Modelling with a Preliminary Experiment
}

\author{
Andrea Lanzini ${ }^{\mathrm{a}}$, Massimo Santarelli ${ }^{\mathrm{a}}$, Gianmichele Orsello \\ ${ }^{a}$ Department of Energy, Politecnico di Torino, Turin, Italy \\ ${ }^{\mathrm{b}}$ TurboCare spa, Turin, Italy
}

\begin{abstract}
Andrea Lanzini
Department of Energy, Politecnico di Torino, Corso

Duca degli Abruzzi 24 -10129, Torino, Italy, phone: +38 011

0904523, fax: + 390110904499 , andrea.lanzini@ polito.it

Massimo Santarelli Department of Energy, Politecnico di Torino, Corso

Duca degli Abruzzi 24 - 10129, Torino, Italy, phone: +38 011

09044 87, fax: + 390110904499 , massimo.santarelli@ polito.it
\end{abstract}
Gianmichele Orsello Turbocare Spa, Corso Romania 661 - 10156, Torino, Italy, phone: $\quad+39 \quad 011 \quad 005 \quad 9931$, gianmichele.orsello@siemens.com

\begin{abstract}
The flexibility and feasibility of a $5 \mathrm{~kW}$ SOFC generator designed for natural gas and fuelled by a non-conventional liquid fuel such ethanol is analysed. A complete generator model is implemented to predict and determine the main criticalities when ethanol fuel is adoperated, The main Balanceof-Plant $(\mathrm{BoP})$ units considered are the reformer, the recirculation system based on an ejector, the tubular cells bundles constituting the stack unit, the after-burner zone and the air blower. The electrical and global efficiencies achieved at nominal operating conditions show how ethanol
\end{abstract}

Deleted: as

Deleted: model of the

Deleted: used

Deleted: as a fuel

Deleted: components

Deleted: the stack with

Deleted: a

Deleted: point are calculated,

Deleted: showing 
maintains generator performance good, while only slightly reducing the system AC efficiency from $48 \%$ (achieved by natural gas) to $45 \%$. The effectiveness and flexibility of the recirculation system when changing the fuel is also verified, since a safe steam-to-carbon ratio (STCR) is established after the fuel is switched from natural gas ehtanol. The stack thermal management is analysed in detail and related to the system performances, showing how a high endothermic fuel reforming reaction is required to maintain the overall system efficiency. A preliminary experiment with ethanol feeding the Siemens generator is finally presented. The system response to the new fuel is monitored by several measured parameters and the system regulation is explained.

\section{Introduction}

Natural gas (NG) is considered the major fuel for SOFCs due to its widespread availability, wellknown catalytic reforming techniques to produce hydrogen and carbon monoxide, and reduced costs. Several SOFC systems running on natural gas are already installed, and some of them have already achieved several operating hours with high conversion efficiency rates for electricity production [1,2]. Still, natural gas is a fossil fuel, and its consumption to produce energy implies having a net balance of $\mathrm{CO}_{2}$ emissions. One attractive feature of SOFC technology is the possibility to operate on different fuels. The relatively high operating temperature permits to have an integrated plant for converting hydrocarbons or alcohols into $\mathrm{H}_{2}$ and $\mathrm{CO}$, which are subsequently electrooxidised in a SOFC to produce electricity).

Among the others, fuels that can be derived from a biological path (e.g. biogases or bio-fuels) are of great interest to assure a sustainable energy production since the net carbon dioxide balance emissions is in principle zero. Of course, depending on the particular fuel composition, a proper device for the catalytic reforming (preferably internally integrated into the stack) has to be selected in order to assure both an adequate conversion of the hydrocarbons or alcohols, as well as to prevent carbon deposition on the anode side of the cells. 
The physical status of a fuel at environmental pressure and temperature is also a feature to consider when selecting a fuel. The general advantage of liquid fuels is the high specific energy density, which translates directly into easier and more convenient storage and transportation, Especially for maritime transportation and aircrafts (where the fuel volume storage is a significant parameter), liquid fuels are of a great interest. One available option is the use of alcohols (e.g. methanol, ethanol, DME) in an SOFC generator with internal or in-stack fuel reforming to provide power to high energy-demanding auxiliary units [3]. Methanol is a good candidate since it is readily available, but usually a fossil fuel such as natural gas or coal is used as the initial feedstock. Moreover, methanol is toxic and special handling and safety issues must be considered. Ethanol is a very promising candidate as well since it can be produced from renewable resources and has no toxicity issues.

In general, an important issue arising when considering bio-fuels, either gaseous or liquid, is how much energy is actually spent to produce a certain available amount fuel starting from the biomass: the debate was and still is very intense, particularly regarding the ethanol production. In fact, the Well-to-Tank (WTT) value of the first-generation bio-ethanol, is around $1.51 \mathrm{MJ} / \mathrm{MJ}$ (mean value obtained from different production pathways), which is still far from the values reached by the traditional fossil fuels (e.g. 0.19 for natural gas) [4]. It has recently been reported [5] that corn ethanol is energy-efficient, as indicated by an energy output/input ratio of 1.34 , while other studies state that producing ethanol requires more energy than that stored in the final fuel [6]. Of course, this clearly depends strongly on the specific production pathway selected and the type of starting biomass.

There is still of course a great opportunity to improve the production and distribution paths of biofuels, and the second generation is developing fast. In addition, bio-ethanol could reach a good performance level in terms of the «generalised» Tank-to-Wheel (TTW) ratio. As shown in the results of this paper, a good electric and CHP efficiency can be reached when a SOFC is used as the device converting the bio-fuel into electricity and heat. 
The consolidated bio-ethanol production technology essentially uses biomass waste as the raw material. Most of the worldwide production relies on the microbial fermentation of sugars (prior eventually the hydrolysis of the starch-containing compounds to the corresponding sugar).

The standard path from sugar (glucose) follows the basic overall reaction:

$$
\mathrm{C}_{6} \mathrm{H}_{12} \mathrm{O}_{6} \rightarrow 2 \mathrm{CH}_{3} \mathrm{CH}_{2} \mathrm{OH}+2 \mathrm{CO}_{2}
$$

Sugarcane (wide production and use in Brazil) or corn (especially in the USS) can be used as feedstock biomass and the two have different ethanol yields per $\mathrm{kg}$ of biomass.

Through hydrolysis, a cellulosic biomass is feasible as well, since enzymes capable of hydrolysing cellulose and preparing it for fermentation have been widely discovered and selected. This technology could turn a number of cellulose-containing agricultural by-products such as corncobs, straw, and sawdust into renewable energy resources. Some enzymes are able to hydrolyse agricultural residues such as corn stover, wheat straw, and sugar cane bagasse as well as energy crops such as switchgrass into fermentable sugars [7].

Ethanol is also relatively easy to convert in hydrogen and carbon monoxide through catalytic steam reforming (which is already generally performed in large SOFC systems to convert natural gas). When bio-ethanol is coupled with a high-energy conversion system, such as an SOFC, a complete sustainable and efficient electricity production is available. For these reasons, an SOFC system fuelled by ethanol is an option worthy of consideration.

\section{Scope of this study}

The main purpose of this study is to establish a detailed and complete modelling framework of an SOFC generator that is able to consider both hydrocarbons and alcohols as fuel inlet, The model is validated against the real generator operating with tubular cells and running on natural gas.

System simulations are performed to show how ethanol could be used to efficiently produce energy (electricity and heat) using an SOFC device as power generator. An experiment with ethanol fuel feeding the real generator is finally performed to check the validity of the simulation results and

Deleted: There is great opportunity for improvement in the production and distribution paths of the bio-fuels, especially considering the use of second generation typologies. Also, bio-ethanol could reach a good performance level in terms of the «generalised» Tank-to-

Wheel $(T T W)$ ratio, because, as described below, a good electric and CHP efficiency can be reached if ethanol would be used in an SOFC plant. II

It has recently been reported [5] that corn ethanol is energy-efficient, as indicated

by an energy output/input ratio of 1.34 ,

while other studies state that producing ethanol requires more energy than that stored in the final fuel [6]. Of course, this clearly depends strongly on the specific production pathway selected and the type of starting biomass. II

Nevertheless,

Formatted: Font: Italic

Deleted: manufacturing

Deleted: and the production techniques have been consolidated through the years.

Deleted: or

Formatted: English (U.K.), Lowered by $6 \mathrm{pt}$

Deleted: $\mathrm{C}_{6} \mathrm{H}_{12} \mathrm{O}_{6} \rightarrow 2 \mathrm{CH}_{3} \mathrm{CH}_{2} \mathrm{OH}+2$ $\mathrm{CO}_{2}$

Deleted: $\mathbb{T}$

Deleted: In general, ethanol production
from biomass with biochemical processes
makes it quite an attractive fuel, provided
that a sustainable pathway is carefully
selected. For non-biological production, $\mathrm{e}$
Deleted: $\mathrm{T}$
If
Deleted: pathway can arise
Deleted: $\mathrm{n}$

Deleted: II

II

Deleted: model

Deleted: s

Deleted: , along with its

Deleted: validation

Deleted: a

Deleted: that

Deleted: s

Deleted: In this study, we

Deleted: aim also to show how

Deleted: device as 
1 support the main findings. In particular, the generator fuel-flexibility is checked with particular concern to the ejector-based recirculation system and the stack thermal management.

\section{Balance-of-Plant of the SOFC system}

In this section, the reference case (a generator fuelled by natural gas) and the proposed alternative generator running on ethanol fuel) are compared together. A wide range of topics related to the operation with a non-conventional fuel are discussed. For both feeding cases, the BoP is maintained the same; in this way, the fuel flexibility of the generator is assessed while the system design and configuration are kept unchanged.

A complete system model of a $5 \mathrm{~kW}$ SOFC generator was developed in the present work. The main modules considered are the fuel processing zone (with a thermally integrated in-stack reformer), the stack unit, the after-burner zone, the ejector-based recirculation system and the cathode air blower, The SOFC system described is representative of the SFCa6 Siemens Fuel Cell design, of which a prototype unit was installed and has been running at Turbocare Spa (Torino) since April 2006.

The stack consists of 88 tubular cells with a $75 \mathrm{~cm}$ active length. The cell design and materials are well known and are reported in [8]. The cells are packed together in a 4 bundles arrangement, each one consisting of 22 tubular cells. Within every bundle, two strings of 11 series-connected cells are connected together in parallel. According to this electrical connection, the voltages produced by the 4 bundles are summed together to provide the overall stack voltage.

\section{Figure 1 - Installation of the $5 \mathrm{~kW}$ Siemens Generator in Turbocare Spa}

The generator has a nominal AC electric power around 3-3.5 $\mathrm{kW}_{\mathrm{el}}$, with a respective DC stack current of $120-150 \mathrm{~A}$ and a voltage of $29-26.5 \mathrm{~V}$. The peak power is $5 \mathrm{~kW}$ DC. The nominal thermal recovered power is in the range of $2.5-3.1 \mathrm{~kW}_{\mathrm{th}}$. The nominal operating temperature of the stack is $970{ }^{\circ} \mathrm{C}$. A scheme of the BoP main modules is presented in Figure 2.

Natural gas is the designed fuel and can be provided directly from the industrial grid, where it is available at pressure of approximately 5 bars. A valve reduces the pressure to a value of 3 bars just

\begin{tabular}{l} 
Deleted: II \\
Moreover, the high \\
\hline Deleted: of an SOFC generator \\
\hline Deleted: shown \\
\hline Deleted: , even \\
$\begin{array}{l}\text { Deleted: when running on a } \\
\text { recirculator-based ejector system with the } \\
\text { new fuel. }\end{array}$ \\
\hline Deleted: solution \\
\hline
\end{tabular}

Deleted: In

Deleted: essentially

Deleted: evaluated

Deleted: considering

Deleted: fixed the

Deleted: module

Deleted: the

Deleted: ventilator

Deleted: , and the recirculation system based on an ejector.

Deleted: has been

Deleted: SOFC

Deleted: stacked

Deleted: a

\begin{tabular}{|l|}
\hline Deleted: (NG) \\
\hline Deleted: pipelines \\
\hline Deleted: with \\
\hline Deleted: an
\end{tabular}


before the generator inlet. As the first step, the fuel enters the desulphuriser, a two reactor beds connected in series, the first one filled with zeolites and the second one with activated carbon, After the cleaning stage, the NG enters the ejector at a pressure that is dependent on the nominal flow. A maximum NG flow of 30 SLPM with an inlet pressure of 2.75 bars is achievable at the ejector inlet. The fuel flow is heated as it is piped inside the hot-box of the system: measurements provide an inlet ejector temperature of around $700^{\circ} \mathrm{C}$. Inside the ejector, the primary fuel (NG) entrains part of the anodic exhaust due to fluid-dynamics effects. By mixing with the latter flow, NG is additionally heated. The recirculation factor of the ejector, and especially the exhaust composition, are strictly dependent on the main operative parameters of the system, which are essentially the Fuel Utilisation $(\mathrm{FU})$ and the current load requested to the stack.

\section{Figure 2 - Basic BoP design of the SOFC generator analysed}

In the system BoP is included an auxiliary steam line used mainly for the start-up and partial load operation of the generator. Under these circumstances, the NG flow entering the generator is much reduced from the nominal value and js unable to entrain water (steam) enough from the anode exhaust to accomplish the reforming reactions, Additional steam is therefore externally added to the stack to guarantee a safe operation in terms of carbon-deposition (that could affect both the $\underline{\text { reformer and the cells catalytic activity and long-term integrity). }}$

With regards to the ethanol feeding case study, the steam line is actually used to pump the ethanol into the ejector. This option was selected since it represented the most convenient and easy way to feed the stack with a liquid fuel. A benefit of dealing with a liquid fuel is that the energy required to pump the fuel into the ejector at an adequate pressure is a negligible fraction of the overall stack power output. Thus the ethanol was pumped at room temperature as a liquid towards the ejector and the stack. Before reaching the ejector, the steamer available was used to vaporise it A more detailed description is reported in the experimental section of this paper,

\section{Cell, stack and system modelling of the $5 \mathbf{~ k W}$ Generator}

\begin{tabular}{l} 
Deleted: inlet into the \\
Deleted: First \\
\hline Deleted: natural gas \\
Deleted: ( \\
Deleted: )
\end{tabular}

Deleted: a

Deleted: at the ejector inlet

Deleted: In the reference case, the NG flow is provided from the industrial grid. A

Deleted: is present

Deleted: and shut-down procedure

Deleted: $s$

Deleted: and in case the

Deleted: .

Deleted: In fact, in this case it

Deleted: enough

Deleted: in

Deleted: recirculated

Deleted: for

Deleted: the

Deleted: ,

Deleted: and a

Deleted: from

Deleted: has to be added in order

Deleted: to operate

Deleted: ly

Deleted: in terms of carbon deposition

Deleted: Referring now

Deleted: to

Deleted: This is quite

Deleted: an

Deleted: procedure

Deleted: , because ethanol is a liquid at room temperature. Another

Deleted: pumping

Deleted: energy to reach the pressure required by the ejector

Deleted: Of course t

Deleted: has to be vaporised, and this step is accomplished in the steamer heat exchanger

Deleted: (a

Deleted: )

Deleted: II

Deleted: S

Deleted: S 
1

2

3

4

5

6

7

8

9

10

11

12

13

\subsection{Tubular cell model}

The Siemens Generator employs cathode-supported tubular cells. The cathode support consists of a $2.2 \mathrm{~mm}$ thick doped $\mathrm{LaMnO}_{3}$ layer fabricated by extrusion-sintering. The inner diameter is $\sim 22 \mathrm{~cm}$. The YSZ electrolyte $(40 \mu \mathrm{m})$, the $\mathrm{Ni}-\mathrm{YSZ}$ anode $(100 \mu \mathrm{m})$ and the doped $\mathrm{LaCrO}_{3}$ interconnector $(100 \mu \mathrm{m})$ layer are successively deposited onto the cathode surface by atmospheric plasma-spraying technique. A thin protective interlayer of $\mathrm{CeO}_{2}$ is deposited between the cathode and the electrolyte using an impregnation technique.

The cathode tube is continuous, generating a seal-less design, where air is always contained on the inside of the cells. Each cell has an uncovered portion of cathode (where nor electrolyte or anode are deposited) where the interconnector layer is placed. A nickel felt is attached onto this layer to provide electrical connection with the other stack cells.

Once the cell geometry and materials are defined, the cell voltage characteristics have been modelled as a function of the current load with a detailed polarisation model. Many models of SOFC single cells exist in the literature; those used here as references are reported in [9-11].

The Nernst potential has been calculated as:

$$
V_{\text {Nernst }}=\frac{R \cdot T}{4 \cdot F} \log \left(\frac{p_{O_{2}}^{\text {channel }}}{p_{O_{2}, a n}^{\text {chat }}}\right),
$$

where the oxygen partial pressures are evaluated respectively in the fuel and air channels, before the gas mixture enters the diffusion zone inside the porous electrodes. The losses arising from the diffusion of reacting and produced species inside the anode and cathode layers are evaluated as concentration losses, as later described.

Ohmic losses occur due to the flow of electrons or ionic species inside the cells. The electron paths inside the cells' active layers due to the particular cylinder shape of the cells have been calculated, along with ohmic losses arising in the Ni-felts and the interconnector contact layers between one 
cell and another. The path is circumferential inside the anode and cathode, and radial into the electrolyte, interconnector and felt. The formulas used are those proposed in [12]:

$$
\begin{aligned}
& \eta_{o h m}^{\text {tot }}=\eta_{\text {ohm,an }}+\eta_{\text {ohm,cat }}+\eta_{\text {ohm,ely }}+\eta_{\text {ohm,int } e r}+\eta_{\text {ohm,felt }} \text {, } \\
& \eta_{\text {ohm }, a n}+\eta_{\text {ohm }, \mathrm{cat}}=j \cdot \frac{\pi D}{2} \cdot\left(\frac{\rho_{a n}}{l_{\text {an }}}+\frac{\rho_{\text {cat }}}{l_{\text {cat }}}\right) \frac{1}{2} \frac{\pi D}{2}, \\
& \eta_{\text {ely }}=j \cdot \rho_{\text {ely }} \cdot l_{\text {ely } 2} \\
& \eta_{\text {ohm }, \text { int } e r}+\eta_{\text {ohm }, \text { felt }}=j \cdot \pi D \cdot\left(\rho_{\text {int } e r} \frac{l_{\text {int } e r}}{w_{\text {int } e r}}+\rho_{\text {felt }} \frac{l_{\text {felt }}}{w_{\text {felt }}}\right)=
\end{aligned}
$$

Figure 3 shows a schematic view of the electrons migrating from the Ni-felt of a cell to that of the subsequent cell, passing through the anode, cathode and electrolyte layer. The current collector zones (interconnector + felt) are located at each semicircle. A uniform current distribution inside the Deleted: $\eta_{\text {ely }}=j \cdot \rho_{\text {ely }} \cdot l_{\text {ely }} \cdot(5) \mathrm{q}$ $\eta_{\text {ohm, int } r}+\eta_{\text {ohm, felt }}=j \cdot \pi D \cdot$ .. (6)

Formatted: Left, Indent: Left: $177.6 \mathrm{pt}$, First line: $34.8 \mathrm{pt}$ tube is assumed.

\section{Figure 3 - Ohmic losses in the tubular cell}

Deleted: cell tube

The anodic concentration losses are evaluated with the flowing expression:

$$
\eta_{\text {diff ,an }}=-\frac{R T}{2 F} \log \left(\frac{p_{H 2, a n}^{\mathrm{int}} \cdot p_{H 2 O, a n}^{\text {channel }}}{p_{H 2, a n}^{\text {channel }} \cdot p_{H 2 O, a n}^{\mathrm{int}}}\right)
$$

Formatted: English (U.K.), Lowered by $17 \mathrm{pt}$

Formatted: Bullets and Numbering

An analogous expression was derived for the $\mathrm{CO}$ diffusion, being this species considered electrochemical active as well as $\mathrm{H}_{2}$ in the proposed electrochemical model.

The Fick's law is solved at the anode to account for the partial pressure change of the gas species

Formatted: Subscript diffusing through the electrode along the anode thickness direction [13]:

$$
N_{i}=-D_{i}^{e f f} \frac{p}{R T} \nabla y_{i}
$$

Since a multi-species gas diffusion is present, the diffusion coefficient of each species inside the mixture is calculated as reported in [14]:

\section{Deleted: using}

Formatted: Bullets and Numbering Deleted: II $N_{i}=-D_{i}^{e f f} \frac{p}{R T} \nabla y_{i} \ldots$ (7)प

Deleted: In the anode, Deleted: . T

Deleted: defined 
1

3

4

5

7

8

9

10

11

12

13

14

15

16

17

18

19

20

21

22

23

24

25

26

27

28

29

30

31

32

33

34

35

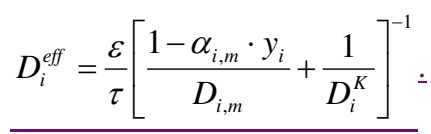

$\alpha_{i, m}$ is a dimensionless parameter defined as:

$$
\alpha_{i, m}=1-\left(\frac{M_{i}}{\sum_{k}^{n_{\text {species }}} M_{k} / n_{\text {species }}}\right)=
$$

$$
D_{i, m}=\frac{1-y_{i}}{\sum_{j \neq i} \frac{y_{i}}{D_{i j}}}
$$

\section{(11)}

where

The dusty-gas model is used at the cathode side [15]. The most significant concentration loss occurs here due to the higher thickness of the cathode compared to the anode layer An higher accuracy is sought when in evaluating this overpotential. The superiority of dusty-gas model with respect to the Fick's law has been reported in literature [16]. The equation for oxygen partial pressure at the cathode/electrolyte interface, considering $\mathrm{O}_{2}$ self-diffusion into the cathode layer, takes the following form once solved:

$$
p_{O_{2}, c a t}^{\mathrm{int}}=\frac{p_{c a t}^{\text {tot }}}{\delta_{\mathrm{O}_{2}}}-\left(\frac{p_{c a t}^{\text {tot }}}{\delta_{\mathrm{O}_{2}}}-p_{O_{2}}^{\text {channel }}\right) \cdot \exp \left(\frac{\delta_{O_{2}} \cdot R \cdot T \cdot j \cdot l_{c a t}}{4 F \cdot D_{O_{2}}^{e f f} \cdot p_{c a t}^{\text {tot }}}\right) 2
$$

where

$$
\frac{\frac{1}{D_{O_{2}}^{e f f}}=\frac{\tau_{c a t}}{\varepsilon_{c a t}} \cdot\left(\frac{1}{D_{O_{2}, K}}+\frac{1}{D_{O_{2}-N_{2}}}\right)}{\delta_{O_{2}}=\frac{D_{i}=-D_{i}^{e f f} \frac{p}{R T} \nabla y_{i}}{D_{O_{2}, K}^{e f f}+D_{O_{2}-N_{2}}^{e f f}}}=
$$

The binary diffusion and Knudsen diffusion coefficients have been calculated according to the Chapman-Enskog kinetic theory [17]. For a low-density gas, the binary coefficients are calculated as: 
where $p$ is the total pressure (in atm), $\sigma_{A B}=(\sigma A+\sigma \underline{B}) / 2$ is the collision diameter (in $\AA$ ) and $\Omega_{D A B}$ is the 'collision integral' for diffusion, based on the Lennard-Jones potential that can be obtained from

$$
\begin{aligned}
& D_{A B}=0.0018583 \cdot\left(\frac{1}{M_{A}}+\frac{1}{M_{B}}\right)^{1 / 2} \cdot \frac{T^{3 / 2}}{p \sigma_{A B}^{2} \Omega_{D A B}}{ }^{2} \\
& \text { ure (in atm), } \sigma_{A B}=(\sigma A+\sigma \underline{B}) / 2 \text { is the collision diameter (in } \AA \text { ㅇ) and } \Omega_{D A B} \text { is } \\
& \text { diffusion, based on the Lennard-Jones potential that can be obtained from }
\end{aligned}
$$
the dimensionless temperature $k T / \varepsilon_{A B}$, where $\varepsilon_{A B}$ is the Lennard-Jones parameter for the energy of molecular interaction, which is expressed in ergs.

The Knudsen diffusion coefficients are calculated as:

$$
D_{A K}=\frac{2}{3}\left(\frac{8 \cdot R \cdot T}{\pi \cdot M_{A}}\right)^{1 / 2} \cdot \frac{1}{2} r_{\text {pore }} .
$$

,The effective diffusion coefficients are evaluated using the Bousanquet formula, multiplying the binary and Knudsen coefficients for the porosity over tortuosity factor.

The cathodic diffusion overpotential is defined as:

Formatted: Bullets and Numbering

\section{Table 1 - Parameters for the cell electrochemical model}

The activation overpotentials are derived from the Butler-Volmer equation, which was obtained in $\eta_{\text {diff, cat }}=-\frac{R T}{4 F} \log \left(\frac{p_{O, \text { accat }}^{\text {int }}}{p_{O 2, \text { cat }}^{\text {chan }}}\right)$ its explicit form by means of the hyperbolic sine approximation. The anodic exchange current has been calculated as reported in [18]:

$$
\frac{j_{0, a n}=\gamma_{a n} \cdot\left(\frac{p_{H_{2}, e q}}{p_{o x, a n}}\right) \cdot \exp \left(-\frac{E_{a c t, a n}}{R \cdot T}\right)}{j_{0, c a t}=\gamma_{c a t} \cdot\left(p_{O_{2}, \text { int }}^{\mathrm{int}}\right)^{0.25} \cdot \exp \left(-\frac{E_{\text {act, cat }}}{R \cdot T}\right)=}
$$

The sum of the anodic and cathodic overpotentials holds the following expression:

$$
\eta_{a c t, a n}+\eta_{a c t, c a t}=\frac{R T}{2 F} \sinh ^{-1}\left(\frac{j}{j_{0, a n}}\right)+\frac{R T}{4 F} \sinh ^{-1}\left(\frac{j}{j_{0, c a t}}\right)=
$$

Formatted: Bullets and Numbering Formatted: Bullets and Numbering Deleted: II $j_{0, a n}=\gamma_{a n} \cdot\left(\frac{p_{H_{2}, e q}}{p_{o x, a n}}\right) \cdot \exp (-$ , . (17) $\mathscr{I}$ $j_{0, c a t}=\gamma_{c a t} \cdot\left(p_{O_{2}, c a t}^{\mathrm{int}}\right)^{0.25} \cdot \exp ($ . (18)I I Deleted: is then Formatted: Bullets and Numbering

The total cell polarisation can finally be written as: 


$$
V(j)=V_{\text {Nernst }}-\eta_{\text {ohm }}^{\text {tot }}-\eta_{\text {act,an }}-\eta_{\text {act, }, a t}-\eta_{\text {diff,an }}-\eta_{\text {diff,cat }}
$$

The set of equations (Eqs. 2-21) provided permits to evaluate the cell polarisation behaviour as a function of the current load requested. The present model was solved for a 1D discretised domain of the tubular cell_(see Figure 4). The domain has been divided into equidistant sectors along the tube length, and the polarisation model is solved for each discretised tube element. Because the gases in each solved tube section diffuse in a direction orthogonal to the fuel flow in the channel, a quasi 2D model is derived. An uniform current distribution along the tube length is assumed. Since both the $\mathrm{H}_{2}$ and $\mathrm{CO}$ coming from the reforming of $\mathrm{CH}_{4}$ are considered as being electrochemical active species, a value of 3 was assumed as the one expressing that ratio between $\mathrm{H}_{2}$ and $\mathrm{CO}$ reacted to provide the overall current requested. This empirical assumption agrees with the literature [11], and in our case it is supported also by the chromatographic analysis of the stack outlet gas which were performed routinely during the generator operation.

Along the tube, the anodic and cathodic gas mixtures change composition according to Faraday's law. At the generic tube element along the domain, the following equations hold:

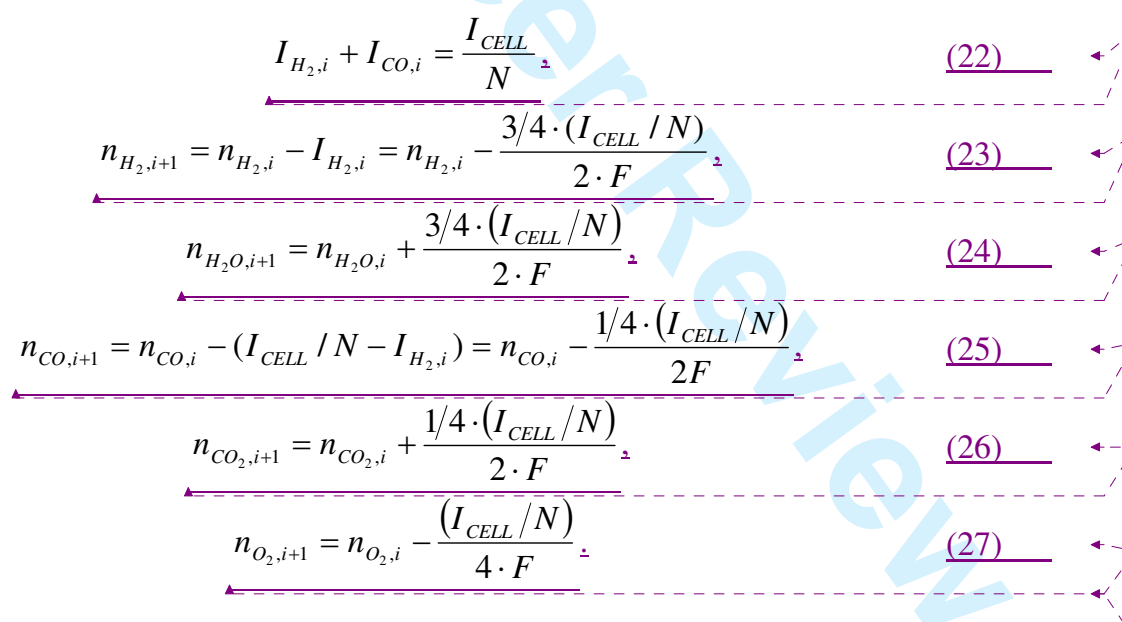

Figure 4 - Fuel and air flows along the tubular cell

\begin{tabular}{|c|c|}
\hline $\begin{array}{l}\text { Formatted: En } \\
\text { by } 7 \mathrm{pt}\end{array}$ & wered \\
\hline Formatted: $\mathrm{Bu}$ & ering \\
\hline $\begin{array}{l}\text { Deleted: } V(j \\
\ldots(20) \mathbb{4}\end{array}$ & $\eta_{\text {ohm }}^{\text {tot }}+$ \\
\hline Deleted: giving & \\
\hline Deleted: under & \\
\hline Deleted: is & \\
\hline Deleted: Becau & \\
\hline Deleted: ( & \\
\hline Deleted: ) & \\
\hline Deleted: availat & \\
\hline $\begin{array}{l}\text { Deleted: to pro } \\
\text { electrochemical o }\end{array}$ & \\
\hline Deleted: e & \\
\hline Deleted: ratio & \\
\hline Deleted: of & \\
\hline Deleted: has be & \\
\hline Deleted: assum & \\
\hline Deleted: to & \\
\hline Deleted: reactin & \\
\hline Deleted: in the & \\
\hline Deleted: fully & \\
\hline Deleted: severa & \\
\hline $\begin{array}{l}\text { Formatted: En } \\
\text { by } 12 \mathrm{pt}\end{array}$ & wered \\
\hline Formatted: $\mathrm{Bu}$ & eering \\
\hline $\begin{array}{l}\text { Formatted: En } \\
\text { by } 12 \mathrm{pt}\end{array}$ & wered \\
\hline Formatted: $\mathrm{Bu}$ & ering \\
\hline $\begin{array}{l}\text { Formatted: En } \\
\text { by } 12 \mathrm{pt}\end{array}$ & wered \\
\hline Formatted: $\mathrm{Bu}$ & ering \\
\hline $\begin{array}{l}\text { Formatted: En } \\
\text { by } 12 \mathrm{pt}\end{array}$ & wered \\
\hline Formatted: $\mathrm{Bu}$ & sering \\
\hline $\begin{array}{l}\text { Formatted: En } \\
\text { by } 12 \mathrm{pt}\end{array}$ & wered \\
\hline Formatted: $\mathrm{Bu}$ & sering \\
\hline $\begin{array}{l}\text { Formatted: En } \\
\text { by } 12 \mathrm{pt}\end{array}$ & wered \\
\hline Formatted: $\mathrm{Bu}$ & Dering \\
\hline Deleted: $I_{H_{2}, i}$ & $\frac{T O T}{N}$ \\
\hline Formatted: Le & \\
\hline Deleted: (21)प & $\ldots[1]$ \\
\hline Formatted & $\ldots[2]$ \\
\hline Deleted: II & \\
\hline
\end{tabular}




\section{Figure 5 - Cells arrangement inside a bundle}

The stack is air-cooled, which means that air in excess to the stoichiometric quantity needed for the electrochemical reactions is used to cool the stack. The stack thermal balance is solved to evaluate the stoichiometric air excess.

The heat internally produced by the stack is calculated as:

$$
Q_{\text {stack }}=Q_{\text {react }}+Q_{\text {loss }}=\left|T_{\text {stack }} \cdot \Delta S_{\text {stack }}\right|+Q_{\text {loss }}
$$

The two heat source terms in Eq. 28 are respectively defined as:

$$
\left\{\begin{array}{l}
T_{\text {stack }} \cdot \Delta S_{\text {stack }}=\Delta H_{\text {stack }}-\Delta G_{\text {stack }} \\
Q_{\text {loss }}=I_{\text {stack }} \cdot\left(\frac{\Delta G_{\text {fuel }(\mathrm{H} 2, \mathrm{CO})}\left(T_{\text {stack }}, y_{\text {fuel }}\right)}{2 \cdot F}-V(I)\right)
\end{array}\right.
$$

Formatted: Font: Not Italic

Deleted: $M$

Deleted: inside the stack

Deleted: in

Deleted: §

Deleted: is just

Deleted:

Deleted: and the results

Deleted: extended

Deleted: $\$$

Deleted: of

Deleted: the

Deleted: a

\begin{tabular}{|l|}
\hline Deleted: bundle is the same, because \\
\hline Deleted: the latter \\
\hline Deleted: are \\
Deleted: The \\
Deleted: therefore \\
Deleted: passin \\
Deleted: $\mathrm{g}$ \\
\hline Deleted: A \\
\hline Deleted: stack \\
\hline
\end{tabular}

Formatted: Left

Deleted: $\mathbb{q}$

Formatted: English (U.K.), Lowered by $7 \mathrm{pt}$

Formatted: Left

Formatted: Bullets and Numbering Deleted: $\mathbb{I}$

$Q_{\text {stack }}=Q_{\text {react }}+Q_{\text {loss }}=T_{\text {stack }}$. (27)

Deleted: $\mathbb{\Psi}$

Formatted: Justified

Deleted: 6

Formatted: Bullets and Numbering 
The first equation refers to the entropic heat of reaction, arising from the electrochemical oxidation of $\mathrm{H}_{2}$ and $\mathrm{CO}$ in $\mathrm{H}_{2} \mathrm{O}$ and $\mathrm{CO}_{2}$ respectively, while the second term is related to the irreversibilities originated by the cells' overvoltages.

The air excess ratio is the parameter used to control the stack temperature; it can be calculated solving the energy balance equations around a control volume representative of the stack itself; the following expression is obtained for the air excess ratio:

$$
\lambda_{\text {air }}=\frac{Q_{\text {stack }}+Q_{\text {ref }}+Q_{\text {fuel }}}{n_{\text {air }, \text { stech }} \cdot \bar{c}_{p, \text { air }}\left(T_{\text {stack }}-T_{\text {air,inlet }}\right)}
$$

The stack air inlet temperature has been set to $750{ }^{\circ} \mathrm{C}$, as measured during the real generator operation. A particular feature of the Siemens BoP is the air pre-heating zone, which is integrated into the stack 'hot-box'. The cathode inlet air enters the generator at the upper side, As the air heads down towards the stack, jt encounters the after-burner unit, just located at the top of generator. In this way, the inlet air, before entering the stack, is preheated to the temperature mentioned before.

$$
\text { 4.3. System model }
$$

Several works on the modelling of a complete SOFC system are available in literature. Notably are those reported in [19-25]; among these, only Riensche et al. [19,20], Marsano et al. [21]. Milewski et al. [22] and Campanari [23] have included an ejector model in their simulations. Of these, just Marsano jncluded a detailed fluid-dynamic description of the ejector-based recirculation system and accounted in his model for a detailed ejector geometry.

The other equations required to describe the generator behaviour consist of mass and energy balances throughout each component of the BoP, coupled to the electrochemical balances and reactions previously described for the stack (which are basically the Faraday's law and an electrochemical polarisation model of the tubular cell). A simple combustion model for the afterburner is used for the stack exhaust burning.

\begin{tabular}{|l|}
\hline Deleted: $\Phi$ \\
II \\
\hline Deleted: expression \\
\hline Deleted:
\end{tabular}

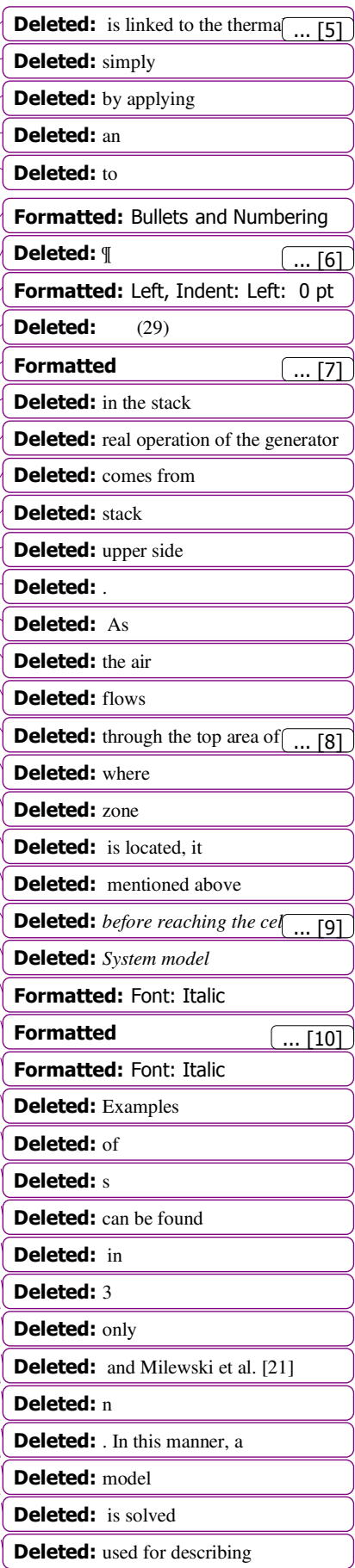


Since gas mixtures are generally present throughout the system (namely $\mathrm{CH}_{4}, \mathrm{C}_{2} \mathrm{H}_{5} \mathrm{OH}, \mathrm{H}_{2}, \mathrm{CO}$, $\mathrm{H}_{2} \mathrm{O}, \mathrm{CO}_{2}, \mathrm{O}_{2}, \mathrm{~N}_{2}$ ), detailed polynomial fitting functions for the specific heats, enthalpies, entropies and Gibbs function values are considered according to the thermochemical data available from the literature $[26,27]$

\subsubsection{Ejector}

The ejector is one of the most important components of the BoP since a proper management of anode recirculation mechanism is crucial to safely operate the generator. The ejector is required to provide the reformer with a sufficient amount of steam, which has to be enough to fully reformate the NG hydrocarbons (of which $\mathrm{CH}_{4}$ is the most abundant) as well as to avoid carbon deposition on the catalyst present in the reformer or in the piping within the generator. The ejector behaviour for $\underline{\mathrm{SOFC}}$ applications is well described $\mathrm{jn}[21,28-30]$. The fluid-dynamic equations used in this work are those proposed by Zhu et al. [28,29]. The ejector has a nozzle where the fuel (natural gas or $\mathrm{NGEtOH} / \mathrm{H}_{2} \mathrm{O}$ as in our case) is injected at a relatively high pressure and accelerated at sonic velocities $(\mathrm{Ma}>1)$. The fuel flow ('primary flow') is thus able to entrain a secondary flow, which is a fraction of the total anodic exhaust produced into the stack. The entrainment is mainly due to $\underline{\text { the combined effects of viscous forces and a local pressure differential occurring at the nozzle outlet }}$ between the primary and the secondary flows. The model considered solves the conservation equations (of mass, momentum and energy) at the main sections of the ejector. The assumption of the fuel reaching a $\mathrm{Ma}>1$ at the nozzle outlet is used to determine the velocity profile of the secondary flow between the primary/secondary streams boundary and the wall. This assumption was verified observing that the inlet fuel pressure measured at the nozzle inlet was always such to enable a critical flow through the nozzle, which indeed means having a $\mathrm{Ma}=1$ at the nozzle throat. Further detail on this aspects are nicely reported in the extensive work on ejectors developed by De Chant [31]. The mass flow of the entrained secondary stream is finally determined integrating the radial velocity profile over the available flow area and multiplying it over the density [28].
Deleted: Because

Deleted: available

Deleted: from

Deleted: 4

Deleted: 5

Deleted: II

II

Deleted: model 
Besides the fuel nozzle area, the ejector includes a mixing zone, where the two flows have time and space enough to get homogeneous before entering the reformer/stack zone, and a diffuser which converts part of the dynamic pressure of the flow into static pressure in order to overcome the reformer and stack fuel compartment pressure drops. A schematic design of the ejector is reported in Figure $\underline{6}$

\section{Figure 6 - Ejector scheme}

The primary flow is accelerated in the nozzle (just convergent in our design) to obtain high entrainment ratios of the secondary flow: the anodic exhaust. The molar entrainment ratio of the ejector is hence defined as the ratio between the recirculated flow (a fraction of the total anodic exhaust) and the incoming fresh fuel:

$$
\omega=\frac{n_{S}}{n_{P}}=\frac{f_{\text {recirc }} \cdot n_{\text {exhaust }}}{n_{\text {fuel }}} .
$$

Since an ejector is generally designed to operate at supersonic speeds, the inlet primary fuel flow passing through the nozzle can be expressed by the following relation:

$$
G_{\text {fuel }}=\sqrt{f_{\text {loss }} \cdot k \cdot R} \cdot\left(\frac{2}{k+1}\right)^{\frac{k+1}{2(k-1)}} \cdot \rho_{\text {fuel }} \cdot A_{t} \cdot \sqrt{T_{\text {fuel }}}
$$

The previous equation expresses the critical mass flowing into a nozzle of a defined geometry (where $A_{t}$ represents the throat area of the nozzle), once provided the thermodynamic properties of the fluid. By substituting the ideal gas law into the density term, the pressure term becomes explicit. As stated before, the ejector has the task of providing enough steam for reforming the NG. Rather than using an external water source, the steam produced by the electrochemical oxidation of $\mathrm{H}_{2}$ is internally "recycled", and part of it is transferred from the stack zone to the reformer zone. At the top of the anodic chamber containing the tubular cells, a duct is placed in such a way to permit part of the anodic exhaust to reach the ejector. The exhaust anodic gas consists of a mixture of unspent fuel $\left(\mathrm{H}_{2}, \mathrm{CO}\right)$, whose quantity depends on the $\mathrm{FU}$ of the generator, and by-products of the
Formatted: Bullets and Numbering

Deleted: $\mathbb{\text { II }}$

$\omega=\frac{n_{S}}{n_{P}}=\frac{f_{\text {recirc }} \cdot n_{\text {exhaust }}}{\text {. . . ( }}$ 30)प Because

Formatted: Bullets and Numbering

Deleted: $\mathbb{I}$

Deleted: $G_{\text {fuel }}=\sqrt{f_{\text {loss }} \cdot k \cdot R} \cdot$ (31)पI

II

Formatted: Indent: Left: 0 pt

Deleted: Substituting

Deleted: the

Deleted: of

Deleted: as 
electrochemical reactions $\left(\mathrm{H}_{2} \mathrm{O}, \mathrm{CO}_{2}\right)$. Since the driving force to entrain the exhaust gas is provided by the accelerated primary fuel (NG) through the ejector nozzle, once the ejector geometry is fixed, the fraction of the anodic exhaust recirculated depends on its molar composition and on the thermodynamic state and mass flow of the primary stream.

\subsubsection{Reformer and after-burner}

The component where the reforming of NG takes place to produce hydrogen and carbon monoxide is the so-called 'in-stack reformer'. The reformer is placed just between the two central bundles of the generator. The BoP has been designed in such a way that the high endothermic reforming reactions receive heat directly from the bundles where heat sources are actually located. The heat exchanged between the reformer and the stack bundles is predominately ruled by radiative phenomena. Since the reformer is receiving heat from the stack, its average temperature is always lower than that of the stack. In our calculations, the reforming equilibrium reactions have been carried out at a temperature of $800^{\circ} \mathrm{C}$. This temperature can be regarded as an average between the reformer inlet and outlet temperatures.

A chemical equilibrium software provided by NASA [24], based on the minimisation of the Gibbs free energy, has been used to determine the equilibrium composition of the flow entering the reformer (fresh fuel + anodic recirculated flow). The NASA code, written in FORTRAN, has been built into a Matlab@ code, which we developed to solve all of the equations reported in the present work.

The reformer is catalysed by $\mathrm{Ni}-\mathrm{Al}-\mathrm{Mg}$ pellets through which the fuel mixture flows. In the real plant operation, up to $95 \%$ of the methane fuel is known to be converted inside the reformer The rest is converted directly over the cells' anode surface. In our calculations, the methane is allowed to react entirely in the reformer. The reformer is treated as being completely selective towards $\mathrm{H}_{2} \mathrm{O}$ in the methane conversion reactions, while the $\mathrm{CO}_{2}$ remains unreacted. In this way, a full steam reforming reaction takes place, while dry-reforming is completely inhibited even if the $\mathrm{CO}_{2}$ is available as significant fraction in the recirculated flow $\mathrm{CH}_{4}$ is by itself thermodynamically more
Deleted: Because

Deleted: when

Deleted: of

Deleted: fluid along with its mass flow Deleted: II

Deleted: hydrocarbons

Deleted: is basically the

Deleted: mean of

Deleted: find

Deleted: our

Deleted: was used

Deleted: this

Deleted: study

Deleted: , as reported by gas analysis measurements

Deleted: .

Deleted: of the $\mathrm{CH}_{4}$

Deleted: ont

Deleted: o

Deleted: all of

Deleted: available

Deleted: almost

Deleted: in reacting with

Deleted: basically

Deleted: A

Deleted: therefore

Deleted:

Deleted: it does not for

Deleted:

Deleted: is

Deleted: in a significant amount

Deleted: ) 
favoured to choose steam rather than $\mathrm{CO}_{2}$, if both available, for its conversion in $\mathrm{H}_{2}$ and $\mathrm{CO}$, but of course is the catalyst chosen inside the reformer that determines the reactions taking place inside it Our assumption is therefore supported by the particular catalyst known to be available in the reformer, The reformer selectivity has been jntrinsically taken into account in our model as a nonreacting $\mathrm{CO}_{2}$ was constrained within the equilibrium routine solved for calculating the reformer outlet composition.

The fraction of the anodic exhaust that is not recirculated join the exhaust air in the upper part of the stack module the after-burner-zone.

The after-burner section is the region where the hot exhaust cathodic air and the non-recirculated fraction of the anodic exhaust mix together in a combustion chamber. What actually burns are the $\mathrm{H}_{2}$ and $\mathrm{CO}$ not consumed by the electrochemical reactions within the stack. The combustion is therefore strictly related to the generator FU. The combustion has been modelled again by a tool available within the NASA program CEA [24], assuming a constant volume and pressure combustion, which is highly representative of what actually takes place in the after-burner region of the generator.

A final consideration has to be made for some internal combustion of $\mathrm{H}_{2}$ and $\mathrm{CO}$ inside the stack, which introduces the concept of fuel consumption (FC). Inside a stack, some air leaks into the anode chamber due to imperfect sealing between the anode and cathode compartments. This phenomenon is due to the alumina structure holding the tubes in place, which is not completely gastight. The $\mathrm{FC}$ is defined as the overall fraction of $\mathrm{H}_{2}$ and $\mathrm{CO}$ consumed inside the stack, either by electrochemical or combustion processes, while the FU just takes into account the electrochemical consumption. For the $5 \mathrm{~kW}$ Generator, the FC is estimated to be around 3\% higher than the FU. Once the leak is fixed, the fuel flow and the operating FU automatically determine the overall amount of $\mathrm{H}_{2}$ and $\mathrm{CO}$ burning inside the stack. This kind of direct internal combustion inside the stack has a detrimental effect not just in terms of wasted fuel, but also in terms of thermal management of the stack itself. The combusted $\mathrm{H}_{2}$ and $\mathrm{CO}$ generate more heat that if they were

\begin{tabular}{|l|}
\hline Deleted: likely \\
\hline Deleted: \\
\hline Deleted: reforming \\
\hline Formatted: Subscript \\
\hline Deleted: but \\
\hline Deleted: is \\
\hline Deleted: especially sensitive to the \\
catalysts chosen inside the reformer \\
\hline Deleted: that play an important role in \\
\hline Deleted: of the reformer \\
\hline Deleted: “ \\
\hline Deleted: " \\
\hline Deleted: the \\
\hline Deleted: equilibrium calculation \\
\hline Deleted: performed in the model, \\
\hline Deleted: imposed as a constraint \\
\hline Deleted: fraction of CO and \\
\hline Deleted: solving \\
\hline Deleted: mixes \\
\hline Deleted: with \\
\hline Deleted: : \\
\hline Deleted: operating FU of the \\
\hline Deled: \\
\hline Dresent in \\
\hline
\end{tabular}

Deleted: ,

Deleted: fixed Deleted: is

Deleted: when they are 
converted electrochemically. We accounted for this phenomenon in our model, and its effect on the air excess is not negligible. Actually taking into account this aspect, the calculated air excess ratio was in a better agreement with the value experienced by the generator during its real operation.

Deleted: at all. Deleted: , considering Deleted: that Deleted: real

Formatted: Bullets and Numbering

\subsection{Model validation}

The complete system model has been validated against experimental data available from the $5 \mathrm{~kW}$

Deleted: whole

Deleted: for the

Siemens generator. The output stack voltage provided by the model matches that of the real system at an operation point within the nominal range of the generator (120 A of stack current and an FU of $85 \%$ ), as well as in a wide interval of off-design points, with a stack current ranging from 100 to 170 A. The voltages predicted by the model reproduce the experimental ones with a maximum relative error of $2 \%$.

The model has been validated for the reference case (NG feeding) also verifying a close match

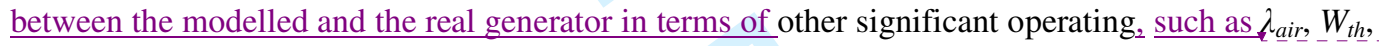
$f_{\text {recirc }}$ and $S T C R$, which were either available from the BoP design or directly measured during the generator operational life,

In particular, the excess air ratio requested by the stack to keep its temperature constant at $970{ }^{\circ} \mathrm{C}$ was calculated by the model with value very close to the real measured one (3.47 against an experimental value of 3.34 , at $120 \mathrm{~A})$.

\section{System simulation results}

Deleted: with respect to
Deleted: ) and
Deleted: considering
Deleted: values measured on the
Deleter SFC5 $\alpha 6$, specifically $W_{e l, D C}$,
Deleted: needed
Deleted: generator
Deleted: obtained by the model
Deleted: $f$ the real generator
Deleted: $\mathbb{1}$
II

The model described in the previous section was solved iteratively as to compute the ejector module an initial guess over the anode recirculated molar fraction was necessary. At each iteration step, the exhaust molar composition is corrected and updated until convergence is reached. A schematic diagram of the iteration step within the system model is shown in Figure $\underline{7}$

Figure 7 - Schematic sheet describing the iteration step for determining the molar composition of the anodic exhaust 
The results of the system model numerical simulations that illustrate the main energy fluxes exchanged within the SOFC generator with two different fuels feeding, methane and ethanol, are respectively reported in Figures 8-9, The simulations are evaluated both at a stack current of $120 \mathrm{~A}$.

\subsection{System modelling of the $5 \mathrm{~kW}$ generator fuelled by natural gas (reference case)}

The system simulation results of the generator running on natural gas are reported in Figure 8. It can be observed how the generator is working with a safe STCR, over 2.5 , and an air excess ratio that is relatively low due the highly endothermic reaction of the methane reforming. The power ratio of the plant (defined as net $\mathrm{AC}$ electrical power output over thermal one) is $\sim 1.15$.

\section{Figure 8 - Detailed flow-sheet with natural gas reference case}

The net electrical AC efficiency is over $48 \%$, which is close to the value observed in the real plant.

Actually, a value around $44-45 \%$ is measured in the real configuration, essentially because of bad inverter efficiency, while in the model a value as high as $95 \%$ was used.

The temperature of the anodic exhaust reaching the ejector has was taken at $925{ }^{\circ} \mathrm{C}$ rather than the $970{ }^{\circ} \mathrm{C}$ of the stack, This correction has been used to match the real operation of the generator, where the anodic exhaust cools down slightly before reaching the ejector. The temperature of the mixed flow at the outside of the ejector is calculated using this corrected temperature. An identical assumption has been made for the ethanol case, where again the secondary ejector flow was set at $925^{\circ} \mathrm{C}$.

Regarding the fuel temperature at the ejector inlet, again a temperature of $700{ }^{\circ} \mathrm{C}$ was experimentally derived. The fuel pipe reaching the ejector passes before through the combustion zone of the stack (the after-burner), where is heated near the temperature indicated above.

A correct determination of the ejector inlet flows' temperatures is fundamental when solving the ejector model to correctly evaluate the thermodynamic state of the inlet flows. 
As a concluding remark on thi section, each flow cooling or heating inside the generator 'hot-box' has always been accounted for in such a way as to preserve the consistency of the energy conservation principle,

\subsection{System modelling of the $5 \mathrm{~kW}$ generator fuelled by ethanol}

The simulation results for the ethanol feeding are reported in Figure 2. Ethanol is provided to the stack through a pump that extracts the liquid fuel from a reservoir tank and conveys it to a vaporiser (steamer of the actual BoP). The power absorbed by this component is a negligible fraction of the electric output of the plant. A favourable feature of dealing with liquid fuels is the possibility of having a pump instead of a compressor to flow the fuel into the ejector, with an associated enthalpy change much lower than that required when compressing a gas.

\section{Figure 9 - Detailed flow-sheet with ethanol feeding}

By comparing the two flow sheets in Figures 8 and 2 it can be concluded that the ethanol feeding produces overall system performances comparable with those achieved with the reference natural gas fuel. The net AC efficiency drops of about 3 points when the fuel is switched from natural gas to pure ethanol, An higher LHV to produce the same overall quantity of stack current is required by the ethanol fuel, This accounts for $\sim 1.5 \%$ of efficiency loss. The remaining loss arises from the higher power consumption of the blower due to the increased air excess of the ethanol-fuelled stack. .The local Nernst voltage curves for NG and EtOH under a stack current of $120 \mathrm{~A}$ are reported in Figure 10. The curves have of course a similar trend, where the voltage drop observed is related to the gradual consumption along the tube of the reactive moles due to the electrochemical reactions occuring in the cell. Apart from the terminal region of the tube, the Nernst cell voltage is always higher for ethanol than for methane. The lower STCR achieved with ethanol means a less-diluted anode fuel which consequently brings a slower descent of the open circuit voltage as the fuel reactive moles $\left(\mathrm{H}_{2}\right.$ and $\left.\mathrm{CO}\right)$ are depleted along the tubular cell channel. Nevertheless, at the tube
Deleted: a general

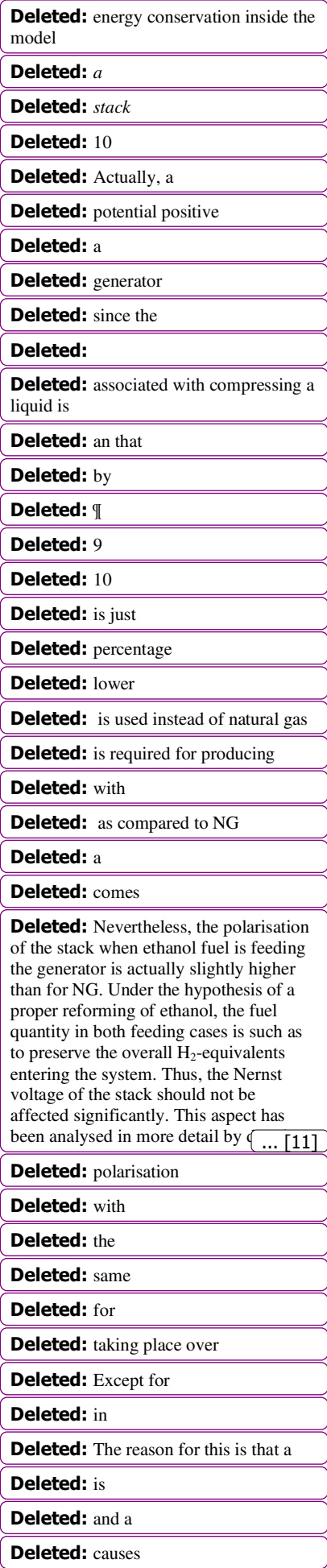


end the lower local FU obtained with the ethanol feeding is responsible for the more pronounced local Nernst voltage drop (see section 5.3 for a detailed explanation of the local FU).

Figure 10 - Comparison of the calculated Nernst voltage along the fuel channel (cell tube

\section{length) for both natural gas and ethanol feeding}

With reference to the ethanol feeding case, the ejector recirculation system is able in principle to provide enough water for the reforming reaction, thus avoiding the need for an external water source; as explained with further detail later in this section, the lower STCR achieved by the ethanol fuel is essentially due to a different exhaust molar composition (richer in $\mathrm{CO}$ ) established in the anodic exhaust.

The lowered STCR achieved is enough to avoid carbon deposition from equilibrium thermodynamic considerations, but its value is just located on the lower bound of a safety range, which generally lies between 2 and 2.5. A possible way to compensate for a too low STCR, without changing the ejector design, could be directly mixing some water with the ethanol feeding stream. $\underline{\text { Since water and ethanol have very similar vaporisation points, they could be easily mixed together }}$ when in the liquid phase, and subsequently vaporised and conveyed together to the ejector nozzle (this will be actually the solution adopted by the Authors in the experimental part of this work).

From the simulations results obtained, a mass entrainment ratio of $\sim 8$ is obtained with NG, while a much lower value of $\sim 3$ is obtained with EtOH. The main reason is that when EtOH is used as a fuel, the primary flow in the ejector nozzle is almost doubled on a mass basis, consequently the available flow area for the secondary stream is significantly decreased, and eventually a reduced entrained secondary flow is obtained (values of $11.0 \mathrm{e}-4 \mathrm{~kg} \mathrm{~s}^{-1}$ and $7.7 \mathrm{e}-4 \mathrm{~kg} \mathrm{~s}^{-1}$ are respectively obtained for NG and EtOH).

The following considerations explain with some more detail why the primary flow increases while chainging the inlet fuel. Ethanol and natural gas have a molecular weight ratio of 46:16, while 2:3 is the ratio established to produce the same amount of electricity regardless of the fuel used (for a 21
Deleted: Figure 9 - Detailed flowsheet with ethanol feeding

Formatted: English (U.K.)

Deleted: The

Deleted: in the ethanol case is in principle able

Formatted: Normal

\begin{tabular}{|l|} 
Deleted: is just \\
Deleted: at \\
Deleted: the \\
Deleted: generally
\end{tabular}

Deleted: The reason for the lower STCR is related to the lowered recirculation factor achieved in the ejector ( 0.52 versus 0.65 with $\mathrm{NG})$; in addition to this, a different exhaust molar composition (richer in $\mathrm{CO}$ ) can lower the STCR (this aspect is discussed further on this paper with more details). The

lowered STCR is enough to avoid carbon deposition, from a thermodynamic point of view.II

Formatted: Superscript 
better clarification on this peculiar feature see Section 6.1 as well). These two ratios should be multiplied together to get the NG:EtOH mass flow inlet ratio. A value close to 2 is obtained, exactly meaning that an almost doubled mass flow passing through the ejector nozzle is established when the fuel is changed from NG to EtOH.

We have now clarified the reasons behind a different mass entrainment ratio between the NG and the EtOH fuels. Nevertheless, the ejector entrainment ratio would be more meaningful if expressed on a molar basis, being the STCR defined on the very same basis. Under the assumption (quite realistic according to our calculations) that the average molecular weight of the anodic exhaust is identical between NG and EtOH, the mass entrainment ratio achieved for each fuel can be related to the molar one by simply multiplying the former ratio for the molar ratio of the two fuels (which is 2:3, according to the strategy of keeping constant the electricity produced by the generator and thus the $\mathrm{H}_{2}$-equivalents number entering the stack). If the value obtained is multiplied over the ratio of secondary mass flows established by each fuel (which is 7.65:11, as reported before), a value close to 1 is now found, meaning that eventually almost the same molar entrainment ratio is obtained for both the fuel feeding cases, consistently also to what reported in Figure 8 and 9.

In Table 2, the molar entrainment ratios and the molar compositions of the recirculated flow for both $\mathrm{NG}$ and $\mathrm{EtOH}$ are reported. The water entrained by the ejector normalised to the molar flow of fuel entering into the stack is reported as well: from now on this parameter will be defined as the $\mathrm{H}_{2} \mathrm{O}$ stoichiometry of the ejector. Otherwise, the STCR is defined according to the following formula:

$$
S T C R=\frac{y_{\mathrm{H}_{2} \mathrm{O}} \cdot n_{\text {an, recirc }}}{n_{\text {fuel }}+y_{\mathrm{CO}} \cdot n_{\text {an,recirc }}}
$$

The difference between the two parameters lies in that the STCR accounts also for the CO in its definition, being this species potentially able to produce carbon deposition as well as $\mathrm{CH}_{4}$.

As shown in Table 2 and provided that methane and ethanol require the same stoichiometric amount of water in the reforming process, the $\mathrm{H}_{2} \mathrm{O}$ stoichiometry achieved for both fuels is
Formatted: Font: (Default) Times New Roman

Formatted: Subscript

Deleted: Referring to the lower entrainment achieved in the ejector with ethanol fuel, a simple explanation is that a lower mass flow (compared to the reference NG) is entering into the fuel nozzle and thus less driving force is available to entrain the secondary flow. A possible way to compensate for this, without changing the ejector design, could be to provide some kind of 'support flow' into the nozzle. Since water and ethanol have very similar vaporisation points, they could be mixed and vaporised together, and then conveyed to the nozzle. In this case the STCR would raise for two reasons: i) a direct one, which of course is due to the extra water present into the ethanol feeding, ii) an indirect one, which is the increase of the entrainment ratio due to the augmented flow entering the nozzle. If

Formatted: Line spacing: Double

Deleted: 1

Deleted: in

Deleted: feeding cases

Deleted: also calculated and

Deleted: stoichs

Deleted: Instead

Deleted: , $\mathrm{t}$

Deleted: as the

Deleted:

Deleted: II

Deleted: II

Formatted: Left

Formatted: Bullets and Numbering

Deleted:

(36)भ

Formatted: Tabs: 460.7 pt, Left

Deleted: $\mathbb{I}$

Deleted: For the fuels consider ... [13] Deleted: is

Deleted: is also accounted for ... [14]

Deleted: recognising it as

Deleted: a

Formatted: Subscript

Deleted: 1

Deleted: considering

Deleted: prcoess

Deleted: stoichs

Deleted: in

Deleted: feeding cases

Deleted: are 
essentially the same. The fact of having a lower STCR for the ethanol is only due to the higher amount of CO present in its anode exhaust gas, as already mentioned before.

\section{Table 2 - Molar compositions of the recirculated flow entrained by the ejector and total}

\section{steam fraction recirculated normalised to the primary flow entering the ejector itself}

The power ratio is $\sim 1$ for the ethanol fuel, meaning that almost the same amounts of electrical and thermal powers are generated. The air excess $\lambda_{-}$is almost $40 \%$ higher than the NG reference fuel, due to an overall less endothermic reaction in the reformer zone. This aspect is further analysed and explained in more detail in the next section, where some experimental evidence is brought to show how the reformer increases its mean temperature due to the presence of a less endothermic reaction when ethanol replaces NG flow.

\subsection{Local FU of the generator}

An useful and meaningful parameter to monitor within the stack is the local FU achieved, The values caclualted for the $\mathrm{NG}$ and $\mathrm{EtOH}$ are respectively $78.0 \%$ and $82.4 \%$

In what following, we briefly derive an expression of local FU in terms of the other significant parameters of the generator.

The local FU is defined as:

$$
F U_{\text {local }}=\frac{I_{\text {ТОT }} / 2 F}{n_{H 2, C O}^{+}}=\frac{F U \cdot\left(1-f_{\text {recirc }}\right)}{1-F U \cdot f_{\text {recirc }}}
$$

The expression in Eq. 34 is derived considering that the molar flow reaching the cell $\left(n_{H 2+C O}^{+}\right)$in terms of $\mathrm{H}_{2}$ and $\mathrm{CO}$ is the sum of two contributions: i) the inlet methane converted in the reformer, and ii) the $\mathrm{H}_{2}$ and $\mathrm{CO}$ present in the recirculated anodic flow. This term is then written as:

$$
n_{\mathrm{H}_{2}, \mathrm{CO}}^{+}=n_{\mathrm{H}_{2}, \mathrm{CO}}^{\mathrm{CH}_{4}}+f_{\text {recirc }} \cdot n_{\mathrm{H}_{2}, \mathrm{CO}}^{+} \cdot\left(1-F U_{\text {local }}\right)
$$

The global FU is defined as:

Deleted: feeding

Deleted: produced

Deleted:

Deleted:

Deleted: which is ascribed

Deleted: shown

Deleted: . In this experiment,

Deleted: $\mathbb{T}$

\begin{tabular}{|c|}
\hline Deleted: It is interesting to evaluate \\
\hline Deleted: \\
\hline Deleted: \\
\hline $\begin{array}{l}\text { Deleted: by each of the two feeding } \\
\text { cases }\end{array}$ \\
\hline Deleted: : \\
\hline $\begin{array}{l}\text { Deleted: with the ethanol fuel and } 78 \% \\
\text { with natural gas. The local FU can be also } \\
\text { directly related to the polarisation } \\
\text { difference observed between the NG and } \\
\text { EtOH feeding cases. II }\end{array}$ \\
\hline Deleted: the \\
\hline
\end{tabular}

II

Formatted: Bullets and Numbering

Deleted: $q$

$F U_{\text {local }}=\frac{I_{\text {TOT }} / 2 F}{n_{H 2, C O}^{+}}=\frac{F U \cdot(1-}{1-F U}$ (32)प

Deleted: 2

Deleted: (in terms of $\mathrm{H}_{2}$ and $\mathrm{CO}$ ) $\mathrm{r}$ Deleted:

Deleted: The

Deleted: overall reactive species can be written as

Formatted: Bullets and Numbering

Deleted: $n_{\mathrm{H}_{2}, \mathrm{CO}}^{+}=n_{\mathrm{H}_{2}, \mathrm{CO}}^{\mathrm{CH}_{4}}+f_{\text {recir }}$ (34)II 


\section{The preliminary experiment with ethanol fuel}

\subsection{Experimental.}

The SFC $5 \mathrm{~kW}$ system has been tested for few hours with a mixture of ethanol and water. During the experiment, the ethanol mixture has been progressively replacing the NG nominal flow, The latter can be calculated once the stack DC current, operating FU and fuel composition are known. The overall fuel, flow required by the stack at a specified current load and FU is given by the following formula:

$$
n_{\text {FUEL }}=\frac{\left(I_{\text {stack }} / 2\right) \cdot n_{\text {cells }}}{2 \cdot F} \frac{1}{H_{2, e q}^{\text {refor } \min g} \cdot F U}
$$

In the above expression, the stack current is related to the molar flow of jnlet fuel. The $\mathrm{H}_{2^{-}}$ equivalents is a value characteristic of each fuel or fuel mixture ${ }_{2}$ By definition, the number of $\mathrm{H}_{2}-$ equivalents expresses how many reactive moles are obtained by an un-reformed fuel mol undertaking a complete steam reforming reaction:

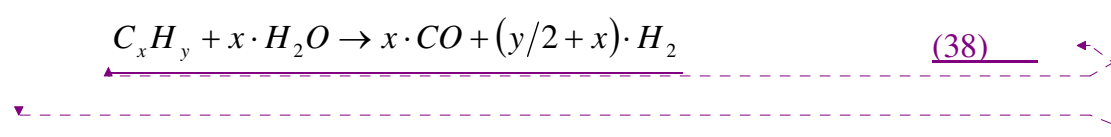


NG is a mixture of various hydrocarbons plus some $\mathrm{N}_{2}$ and $\mathrm{CO}_{2}$ in small amounts. The composition

varies from site to site, and significant differences in the methane content subsist over the different countries. From the data records on the NG composition available in Turbocare Spa (IT - Torino), the gas from the grid contained on average a methane fraction of 91-92\%.

For simplicity, we always considered the NG as composed of just methane in all our simulations. This of course leads to some inaccuracy in the results obtained. Nevertheless the error was estimated to be less than $1 \%$ in the evaluation of the system efficiencies.

The basic idea under which part of the nominal NG flow has been replaced with EtOH was to provide the generator always with the same amount of $\mathrm{H}_{2}$-equivalents. The reforming reactions of methane and ethanol are respectively the following;

$$
\frac{\mathrm{CH}_{4}+\mathrm{H}_{2} \mathrm{O} \rightarrow 3 \mathrm{H}_{2}+\mathrm{CO}, \quad \Delta H_{298 K}^{0}=-206.33 \mathrm{~kJ} \mathrm{~mol}^{-1}}{\mathrm{C}_{2} \mathrm{H}_{5} \mathrm{OH}+\mathrm{H} 2 \mathrm{O} \rightarrow 3 \mathrm{H}_{2}+\mathrm{CO}, \quad \Delta \mathrm{H}_{298 \mathrm{~K}}^{0}=-256.79 \mathrm{~kJ} \mathrm{~mol}^{-1}}
$$

It is trivial to see how 1 mole of fully steam-reformed ethanol gives $\overline{6} \overline{\mathrm{H}}_{2}$-equivalent reactive moles $\left(\mathrm{H}_{2}+\mathrm{CO}\right)$ compared to the 4 provided by the methane undertaking the same kind of reforming reaction. The $6: 4$ ratio obtained is also the one driving the switch from NG to ethanol fuel,

Looking at the reactions listed above, the enthalpy reaction for $\mathrm{EtOH}$ reforming is higher than for $\mathrm{CH}_{4}$; but , since for each $\mathrm{CH}_{4}$ mole just 4:6 $\mathrm{EtOH}$ moles are needed, the heat absorbed by the fuel reforming changes with this ratio as well. Considering that the $\mathrm{H}_{2}$-equivalent moles are kept the same in both feeding cases, the heat of the reforming reactions for NG is is 1.2 higher than that required to reformate $\mathrm{EtOH}_{y}$ Therefore, fuelling the stack with ethanol reduces the heat sink of the reforming reaction. As a direct consequence, a higher air mass flow is necessary to keep the temperature constant inside the various cell bundles (this aspect is also clear from the system simulation results reported in Figures 8 and 9, where the EtOH feeding case requires a $\lambda_{\text {air }}$ of 5 against a 3.5 value attained by NG).

The ethanol was not flowed pure to the stack, rather an EtOH/H2O mixture was used. The water/ethanol ratio has been set in order to operate the system in safe conditions towards the carbon
Deleted: , upon...stack fuel ....removed and .... an ... mixture, ... always ... an overall fuel mixture that was able to provide the stack with the same amount of equivalent reactive moles of $\mathrm{H}_{2}$ of the nominal NG flow, while undertaking a full steam-reforming

Deleted: Taking a closer observation at the..., we hav....e

Formatted: Subscript

Formatted: English (U.K.), Lowered by $6 \mathrm{pt}$

Formatted: Bullets and Numbering

Formatted

Formatted: Bullets and Numbering Deleted: $\mathbb{I}$

Deleted: $\mathrm{CH}_{4}+\mathrm{H}_{2} \mathrm{O} \rightarrow 3 \mathrm{H}_{2}+\mathrm{CO}$, $\left(\Delta \mathrm{H}_{\text {react }}(298 \mathrm{~K})=206.33 \mathrm{~kJ} \mathrm{~mol}^{-1}\right)$ (39)पI

$\mathrm{C}_{2} \mathrm{H}_{5} \mathrm{OH}+\mathrm{H}_{2} \mathrm{O} \rightarrow 4 \mathrm{H}_{2}+2 \mathrm{CO},\left(\Delta \mathrm{H}_{\mathrm{reac}}\right.$ $\mathrm{C}_{2} \mathrm{H}_{5} \mathrm{OH}+\mathrm{H}_{2} \mathrm{O} \rightarrow 4 \mathrm{H}_{2}+2 \mathrm{CO},\left(\Delta \mathrm{H}_{\text {reac }}\right.$
$\left.(298 \mathrm{~K})=256.79 \mathrm{~kJ} \mathrm{~mol}^{-1}\right) . \quad(40)$ ) that a ..., when fully steam-refor ... [23] Formatted: Subscript

Deleted: moles ...per mole of steamreformed... ....is ...ratio ...es..., thus maintaining the number of $\mathrm{H}_{2}$-equivalents constant.

Formatted: Subscript Deleted: /... in-stack

Deleted: imposed . to be ... required ...for a NG...feeding than for an... feeding... aspect ...fully evident in... ...4.7 instead ... of .... with $N_{\text {... [ [26] }}$ Formatted: Subscript 
deposition. In Figure 11, using the CEA chemical equilibrium software [24], the mixture equilibrium composition as a function of temperature are plotted for a liquid volumetric EtOH/ $\mathrm{H}_{2} \mathrm{O}$ ratio of 60/40 (the ratio shifts to 33.3/66.7 with the species in the gas phase). The graph shows how the water content in the mixture is already enough to suppress carbon deposition at temperatures above $600{ }^{\circ} \mathrm{C}$.

\section{Figure 11 - Equilibrium compositions of an ethanol/water mixture in a volumetric ratio 60/40}

\section{at different temperatures}

At the stack's nominal operating condition (120 Amps), the ethanol supplied was 3.5 SLPM, while the total $\mathrm{EtOH} / \mathrm{H}_{2} \mathrm{O}$ mixture was almost $11 \mathrm{SLPM}$; the NG flow was correspondingly decreased to less than 6 SLPM.

The EtOH/ $\mathrm{H}_{2} \mathrm{O}$ mixture has been supplied through the steam line of the generator; this line was already installed from the beginning in the BoP to provide external steam during start-up and shutdown procedures and at off-load operation. Under these circumstances, either the anodic recirculation flow rich in $\mathrm{H}_{2} \mathrm{O}$ or $\mathrm{CO}_{2}$ is not available or low to guarantee a safe steam reforming of the NG. The external water reservoir was with and the liquid $\mathrm{EtOH} / \mathrm{H}_{2} \mathrm{O}$ mixture. The latter was vaporised in the steamer, and pumped to the stack ejector inlet with a volumetric pump. A schematic view of the experiment set-up is shown in Figure 12.

\section{Figure 12 - Schematic view of the $5 \mathrm{~kW}$ Generator to respect of the fuel and air feeding flows}

The choice of passing the EtOH/ $\mathrm{H}_{2} \mathrm{O}$ mixture into the ejector is worthy of discussion because the steam already present in the EtOH mixture is enough to suppress carbon deposition at the reformer temperature, as mentioned before. Figure 13 reports the carbon boundary of the ethanol steam reforming reaction calculated using again thermodynamic equilibrium considerations. At $700{ }^{\circ} \mathrm{C}, 2$ mol of $\mathrm{H}_{2} \mathrm{O}$ are sufficient to suppress carbon deposition, while even less are required as the temperature grows. Since this was a preliminary experiment, our choice was motivated by safety, meaning that a high amount of $\mathrm{H}_{2} \mathrm{O}$ to suppress carbon deposition was voluntarily injected along with the $\mathrm{EtOH}$ fuel. The extra steam provided with the exhaust flow recirculated by the ejector

Deleted: 8
Deleted: by means of
Deleted: a
Deleted: $s$
Deleted: against
Deled: , referring to the species in the
Deleted: in the
Deleted:

Deleted: simultaneously

Deleted: of the system

Deleted: when

Deleted: , or generally when the load is too low to electrochemically provide an internal steam production

Deleted:

Deleted: steamer

Deleted: has been filled

Deleted: both water and

Deleted:

Formatted: Subscript

Deleted: either in a liquid state or

Deleted: by electric heating

Deleted: then

Deleted: It can be seen that a

Deleted: Because 
satisfied our safe operation requirement. In addition, it has been reported that ethanol steamreforming in $\mathrm{H}_{2}$ and $\mathrm{CO}$ is more difficult than methane reforming [32].

Obviously this extra-safe operating condition reduced stack performances, since an excessively high water dilution of reformed fuel negatively affects the Nernst voltage of the fuel mixture entering the stack anode compartment as well as increases the cell overvoltages. This point js discussed with more deital jn the next section, where the experimental results are reported.

Figure 13 - Carbon boundary for the ethanol steam reforming

\subsection{Results}

In Figure 14, the NG and EtOH flow are plotted along with the measured ejector primary pressure, As already described before, the fuel feeding strategy was to gradually substitute the NG flow with EtOH while keeping constant the $\mathrm{H}_{2}$-equivalents produced respectively by the two fuels, and assuming a complete steam reforming reaction occurring. Thus the mixture entering the ejector (primary flow) consisted partly of $\mathrm{NG}$ from the grid and partly vaporised EtOH/ $\mathrm{H}_{2} \mathrm{O}_{\vee}$ A complete substitution of NG with ethanol maintaining the nominal stack current load was not possible due to a limitation on the maximum capacity of the pump extracting the liquid fuel from the tank. A maximum EtOH volumetric flow of $15 \mathrm{cc} \mathrm{min}^{-1}$ was achieved, In terms of $\mathrm{H}_{2}$-equivalents, at the maximum EtOH feeding, half of the generator current load was provided by ethanol, while the remaining half was covered by $\mathrm{NG}_{\rightarrow}$

\section{Figure 14 - Ejector pressure increase during EtOH/H2O mixture feeding}

In Figure 14, the volumetric flows of NG and EtOH (60\% vol. of EtOH tank mixture) are plotted aganst the volumetric $\mathrm{EtOH} / \mathrm{H}_{2} \mathrm{O}$ mixture pumped from the jiquid reservoir tank, The graph reports the approximate behaviour of the water finally present in the $\mathrm{EtOH} / \mathrm{H}_{2} \mathrm{O} / \mathrm{NG}$ conveyed into the stack during the experiment. The initial water content in the primary fuel is due to the water already present inside the EtOH/ $\mathrm{H}_{2} \mathrm{O}$ feeding tank. After the ejector, due to the mixing with the recirculated fraction of the anodic exhaust, the overall water content further jncreases. The hypothesis that the
Deleted: , as also

Deleted: later

Deleted: along with

Deleted: Experimental result
Deleted: against time, and
Deleted: is reported
Deleted: in feeding the stack
Deleted: ethanol
hydrogen:
Formatted: Subscript
Deleted: reactive moles producible
Deleted: Due to the maximum capacity
of the pump extracting the liquid from the
tank, a maximum volumetric flow of 15
cc min ${ }^{-1}$ of EtOH mixture was achieved

Deleted: while also maintaining the nominal stack current load

Deleted: With respect to

Deleted: by

Deleted: and the remaining half by ethanol.

\begin{tabular}{|l|}
\hline Deleted: the \\
\hline Deleted: versus \\
\hline Formatted: Subscript \\
\hline Deleted: ing of the latter tank mixtur \\
Deleted: e \\
\hline Deleted: aims to give \\
\hline Deleted: The ini \\
\hline Deleted: tial \\
\hline Deleted: total \\
\hline
\end{tabular}


normalised molar steam flow entrained by the primary flow is constant was assumed. In Figure 15 , $\underline{\text { the } \mathrm{H}_{2}} \underline{\mathrm{O} \text { stoichiometry behaviour is plotted against an increasing EtOH} / \mathrm{H}_{2}} \underline{\mathrm{O} \text { feeding. As stated }}$ before, the $\mathrm{H}_{2} \mathrm{O}$ stoichiometry represents the actual steam available in the final mixture flowing into the ejector over the stoichiometric water needed for the steam reforming reaction of the NG or $\underline{\text { EtOH (it should be noted that both fuels need only } 1 \mathrm{~mol} \mathrm{of} \mathrm{H}_{2}} \underline{\mathrm{O} \text { for accomplishing the conversion }}$ reactions).

The hypothesis made can be only partially justified from what is reported in Table 2 , where very similiar values for the entrainment ratios and steam-to-fuel ratios are achieved regardless of the fuel. In the experiment, the ethanol is already pre-mixed with some water from the liquid reservoir tank. With respect to the the pure ethanol feeding modelled before, now we have an even further increased mass flow entering the fuel nozzle. Such an increased mass flow could actually prevent a proper entrainment of the secondary flow. This is the reason why the assumption of a constant molar entrainment ratio of the ejector during the ethanol experiment, can not certainly considered a conservative one. The $\mathrm{H}_{2} \mathrm{O}$ stoichiometry value reported in Figure 15 is probably somewhat higher than the value actually experienced by the reformer.

\section{Figure 15 - Water stoichiometry in the NG/EtOH mixture reaching the stack}

According to Figure 15, and to our recommendations about the not-conservative feature of our assumption on the ejector entrainment during the experiment, the steam excess in the fuel flow entering the stack could be regarded as only slightly increased to respect of the nominal NG feeding, This aspect should produce a negative effect on the stack voltage, as already outlined, which is indeed confirmed by the experimental data in terms of a decrease of the stack voltage. In Figure 16 , it is evident how the stack voltage reaches a minimum when the EtOH/ $\mathrm{H}_{2} \mathrm{O}$ mixture is at the maximum level. The voltage loss is quite limited, though: less than $1 \mathrm{~V}$ is lost when partly switching the fuel from NG to EtOH as in our experiment. During the experiment, the stack current was kept constant managing the generator control system to force the stack to provide a set amount of current. The system demonstrated the ability to convert the new fuel into $\mathrm{H}_{2}$ and $\mathrm{CO}$ and to
Deleted: was made

Deleted: This assumption means that the ejector is working in a rather flat area of its characteristic curve, where the recirculation factor is almost constan (flat) when varying the inlet primary flow

\begin{tabular}{|c|}
\hline Deleted: . Such a \\
\hline Deleted: could \\
\hline Deleted: also \\
\hline Deleted: presented \\
\hline Deleted: 1 \\
\hline Deleted: quite \\
\hline Deleted: similar \\
\hline Formatted: English (U.K.) \\
\hline Formatted: English (U.K.) \\
\hline Formatted: English (U.K.) \\
\hline Formatted: English (U.K.) \\
\hline Formatted: English (U.K.) \\
\hline Formatted: English (U.K.) \\
\hline Formatted: English (U.K.) \\
\hline Formatted: English (U.K.) \\
\hline Formatted: English (U.K.) \\
\hline Formatted: English (U.K.) \\
\hline Formatted: English (U.K.), \\
\hline Formatted: English (U.K.) \\
\hline Formatted: English (U.K.) \\
\hline $\begin{array}{l}\text { Deleted: In Figure } 15 \text {, the } \mathrm{H}_{2} \mathrm{O} \text { stoichs } \\
\text { behaviour is plotted against an increasing } \\
\text { EtOH/ } \mathrm{H}_{2} \mathrm{O} \text { feeding. As stated before, the } \\
\mathrm{H}_{2} \mathrm{O} \text { stoichs represent the excess steam } \\
\text { present in the final mixture flow that exits } \\
\text { the ejector with respect to the } \\
\text { stoichiometric water needed for the steam } \\
\text { reforming reaction of the NG or ethanol } \\
\text { fuel (it should be noted that both need } 1 \\
\text { mol of } \mathrm{H}_{2} \mathrm{O} \text { to reform one mol of } \mathrm{CH}_{4} \text { or } \\
\text { EtOH, respectively). If }\end{array}$ \\
\hline Deleted: stoichs \\
\hline Deleted: $T$ \\
\hline Deleted: total \\
\hline Deleted: s \\
\hline $\begin{array}{l}\text { Deleted: due to water present in the } \\
\text { EtOH flow }\end{array}$ \\
\hline $\begin{array}{l}\text { Deleted: , which increases during the } \\
\text { ethanol experiment as well }\end{array}$ \\
\hline Deleted: 5 \\
\hline Deleted: gives \\
\hline Deleted: value \\
\hline Deleted: by \\
\hline Deleted: of the generator so as \\
\hline Deleted: the \\
\hline
\end{tabular}


provide the requested current. This represents only a preliminary result and longer experiments should be carried out to fully demonstrate the fuel flexibility of the generator. The durability of the reformer against a new fuel and the possible formation of carbon deposits in a long-term period are aspects that should addressed with more detail in the future.

The $1 \mathrm{~V}$ loss could be also partially ascribed to a not proper or full conversion of the EtOH stream inside the reformer and the stack. Nevertheless, the increased water dilution of the fuel seems to be a much more plausible explanation. If a not proper catalytic conversion of ethanol was occurring, a more pronounced stack voltage loss and instable generator behaviour would have been observed.

Figure 16 - Behaviour of stack voltage during the EtOH/H2O feeding experiment In Figure 17, the voltage behaviour for each stack string is reported (each bundle is divided into two strings electrically connected in parallel for a total number of 4 bundles inside the stack: the 4 voltages for the generator that can be read in the system data logger are representative of each bundle voltage). The zoom is now on a wider time interval than in Figure 16. Two EtOH testing phases can be distinguished. The first one was just a short trail, while the second one is the experiment discussed and reported in Figure 16. Referring again to Figure 17, it is interesting to see to what extent the string voltages were perturbed each time the ethanol fuel began to flow into the stack.

\section{Figure 17 - Comparison of string voltages during the $\mathrm{EtOH} / \mathrm{H} 2 \mathrm{O}$ feeding experiment}

In Figure 18, on the same time interval as Figure 17, the stack current and voltage are reported during the experiment. As mentioned before, the current was kept constant during the experiment.

The increase in the last part of jt occurs when the EtOH flow has already reached its maximum and the NG nominal flow is restored. Regarding the behaviour of the generator control system, the current is generally defined as an external input that the stack is forced to match. However, when the voltage goes down below the set value, the control system automatically reduces the current requested to the stack. In Figure 18 is shown how the current was effectively kept constant during
Deleted: especially be assessed Deleted: The reformer is a component to be carefully selected and maybe reconsidered in the current system design in order to guarantee stability against fuels different from NG.
Deleted: was used

Deleted: 3

Deleted: is

\begin{tabular}{|l|}
\hline Deleted: experiment that is \\
\hline Deleted: \\
\hline Deleted: In \\
Deleted: also quite \\
Deleted: clear how \\
Deleted: was \\
Dermatted: Normal, Justified, Line \\
Deleted: in \\
Deleted: and current \\
Deleted: It can be seen that $t$ \\
\hline Deleted: the text \\
\hline
\end{tabular}

Deleted: tries

Deleted: In

Deleted: 6 , it can be seen that

Deleted: the voltage

Deleted: constant 
the ethanol feeding to value only slightly lower than that achieved by NG before the EtOH feeding perturbations

Deleted: long ..., but ...the var ... [28]

Formatted: English (U.K.)

\section{Figure 18 - Stack voltage and current behaviour}

Figure 19 reports the temperature drop across the reformer as measured during the ethanol feeding.

The temperature decreases across this component due to the endothermic reforming reactions occuring in it. Since the steam reforming of EtOH normalised to the $\mathrm{H}_{2}$-equivalents is somewhat less endothermic than that of methane (as previously predicted by the system modelling results as well as by simple thermodynamic calculations on the enthalpies of reaction), a less pronounced temperature drop is indeed observed in the reformer, providing experimental evidence to our previous calculations. It is worth to note how the temperature drop is the lowest when the EtOH feeding is the highest, as we expected.

\section{Figure 19 - Reformer temperature drop during the ethanol experiment}

In Figure 20, the temperature behaviour of different regions inside the generator js reported. For the reasons already discussed before, the temperature drop across the reformer decreases when ethanol replaces methane, Reagarding the absolute temperature of the inlet reformer, it jncreases. This temperature is related to the mixing of the fresh fuel and the recirculated flow occurring in the ejector. Such an increase could be explained by a hotter recirculated exhaust coming from the stack.

Figure 20 こ Generator temperatures behaviour during the ethanol experiment

The air stoichiometry (air excess ratio) is reported in the same graph. The generator control system varies this parameter in such a way as to keep the stack temperature constant. Since a less endothermic reforming reaction is taking place, the stack temperature would increase if the air excess ratio would remain the same when switching the fuel from methane to ethanol, This effect is avoided by the control system increasing the air flow into the stack, leading to an augmented cooling of the generator. The air flow in the generator (and consequently the air stoichiometry 
number) is also regulated by the control system to avoid an excessively high temperature increase in the after-burner zone. As reported in Figure 20, when ethanol was provided to the stack, the burner temperature increased by $\sim 30^{\circ} \mathrm{C}$. The increased air flow in the stack could therefore have occurred to compensate for this phenomenon From Figure 20, and according to the temperatures and air flow behaviours measured $d_{\text {s }}$ the second option looks like as the more plausible In fact, there is some evidence on how the after burner temperature compensation brought an extra-cooling of the stack at the end of the experiment.

Figure 21 shows how the measured $\mathrm{AC}$ efficiency of the system varies during the ethanol experiment. The efficiency reaches its minimum when the ethanol flow is at its maximum, following the behaviour of the voltage. The decrease is only around $1 \%$, underlining how ethanol could substitute methane without any appreciable system performance modifications.

\section{Figure 21 - Generator electrical AC efficiency behaviour during the EtOH experiment}

\section{Conclusions}

An SOFC tubular generator has been studied and modelled in detail. The main system components and the stack polarisation behaviour have been accounted for within the model. Among the system components, particular consideration was dedicated to the ejector and its role inside the generator as a whole.

The ejector flexibility to a fuel such as ethanol has been theoretically predicted. A safe generator operation could be guaranteed in terms of STCR with the new fuel. The thermal management of stack and its link to the reforming of the inlet fuel has been clearly established: it has been shown how a fuel alternative to NG could be used successfully, without significantly degrading the system performance, provided that a high endothermic conversion of the fuel within the reformer occurs. According to our analysis, a multi-fuel generator running both on natural gas and ethanol could be feasible. Concerning the actual BoP, the only critical aspect identified is represented by the catalyst

\begin{tabular}{|c|}
\hline $\begin{array}{l}\text { Deleted: not only for keeping the stack } \\
\text { temperature constant at a desired set- } \\
\text { point, but also }\end{array}$ \\
\hline Deleted: 18 \\
\hline Deleted: as \\
\hline Deleted: , so t \\
\hline Deleted: could be actually \\
\hline Deleted: attributed to this \\
\hline Deleted: as well \\
\hline Deleted: . II \\
\hline Deleted: From the \\
\hline Deleted: s \\
\hline Deleted: of temperatures and air flow \\
\hline Deleted: and reported in Figure 18 \\
\hline Deleted: , it looks like \\
\hline Deleted: is the \\
\hline Deleted: \\
\hline $\begin{array}{l}\text { Deleted: one: the air flow has been } \\
\text { growing more to compensate for the high } \\
\text { temperature reached in the after-burner } \\
\text { rather than to control the stack } \\
\text { temperature }\end{array}$ \\
\hline Deleted: . \\
\hline Deleted: It can be seen in Figure 18 \\
\hline Deleted: that \\
\hline $\begin{array}{l}\text { Deleted: the stack is indeed extra- } \\
\text { cooled }\end{array}$ \\
\hline $\begin{array}{l}\text { Deleted: In Figure } 21 \text {, it is also } \\
\text { interesting to observe how the inlet } \\
\text { reformer temperature behaves similarly to } \\
\text { that of the after-burner. The reformer } \\
\text { temperature is governed by the fuel inlet } \\
\text { temperature and the anodic exhaust } \\
\text { temperature. If we consider the fuel inlet } \\
\text { temperature to be constant, the anodic } \\
\text { exhaust temperature is the one really } \\
\text { affecting and governing that of the inlet } \\
\text { reformer zone. We should also consider } \\
\text { that the anodic exhaust has basically the } \\
\text { same temperature of the stack at } \ldots \text { [37] }\end{array}$ \\
\hline Deleted: 2 \\
\hline Deleted: 2 \\
\hline Deleted: the \\
\hline Deleted: considered \\
\hline Deleted: in \\
\hline Deleted: attention \\
\hline Deleted: has been paid \\
\hline Deleted: The local FU has beer ... [38] \\
\hline Deleted: and it has been shown how a \\
\hline Deleted: of the system \\
\hline Deleted: Based on \\
\hline Deleted: multi-fuel \\
\hline Deleted: on \\
\hline
\end{tabular}


1 reformer, whose stability and reforming activity against fuels different from NG should be proven on the long run.

A preliminary experiment was finally performed to verify what predicted by the system numerical simulations and prove the feasibility of ethanol as a fuel for a SOFC generator. A good integration of this fuel has been verified with respect to the ejector recirculation system and the stack thermal balance. In particular, the reformer behaviour was qualitatively in agreement with what theoretically expected. The electrical efficiency achieved by an ethanol-fuelled SOFC system is comparable to that of an NG fuelled one. In addition, a SOFC generator capable of running on multi-fuels shows to be a viable option.
Deleted: the reformer should be carefully checked in terms of catalyst Deleted: for

\begin{tabular}{l} 
Deleted: has been \\
Deleted: also conducted \\
Deleted: verify \\
Deleted: is \\
Deleted: to \\
Deleted: an \\
Delet: feeding within the \\
Deleted: stack \\
Deled: fully \\
Deleted: and \\
Deleted: multi-fuel \\
Deleted: running on both fuels \\
\hline Deleted: interesting \\
\hline
\end{tabular}

\section{Deleted: II}

II 


\section{Nomenclature}

$A_{t} \quad$ throat area of fuel nozzle inside the ejector $/ \mathrm{m}^{2}$

BoP balance-of-plant

$D \quad$ mean tubular cell mean diameter / $\mathrm{m}$

$D_{i} \quad$ diffusion coefficient of species $i / \mathrm{cm}^{2} \mathrm{~s}^{-1}$

$D_{i}^{K} \quad$ Knudsen diffusion coefficient of species $i / \mathrm{cm}^{2} \mathrm{~s}^{-1}$

$E$ activation energy $/ \overline{\mathrm{J}} \mathrm{mol}^{-1}$

EtOH abbreviation for ethanol

$F \quad$ Faraday constant / $96485 \mathrm{C} \mathrm{s}^{-1}$

$f_{\text {loss }} \quad$ frictional loss coefficient

$F_{\text {recirc }} \quad$ recirculated fraction of the anodic exhaust

FU (global) fuel utilisation (referring to the inlet NG flow)

$F U_{\text {local }} \quad$ effective fuel utilisation experienced by the stack

$G_{a n, \text { exhaust }}$ exhaust anodic flow exiting the stack $/ \mathrm{kg} \mathrm{s}^{-1}$

$G_{\text {fuel }} \quad$ fuel flow into the ejector $/ \mathrm{kg} \mathrm{s}^{-1}$

$G_{\text {ref }} \quad$ mixed fuel flow entering the reformer $/ \mathrm{kg} \mathrm{s}^{-1}$

$G_{\text {stack,inlet }}$ reformed fuel flow entering the stack anode side $/ \mathrm{kg} \mathrm{s}^{-1}$

$\mathrm{H}_{2, e q} \quad \mathrm{H}_{2}$-equivalents

$\mathrm{H}_{2} \mathrm{O}$ stoichiometry moles of $\mathrm{H}_{2} \mathrm{O}$ (steam) over stoichiometric moles of $\mathrm{H}_{2} \mathrm{O}$ for reforming a - Deleted: stoichs selected fuel

I electric current / A

$I_{C E L L} \quad$ electric current of a single cell / A

$I_{\text {TOT }} \quad$ total current requested/produced by all the stack cells $\left(=n_{\text {cells }} \cdot I_{\text {cell }}\right) / \mathrm{A}$

j $\quad$ current density $/ \mathrm{A} \mathrm{cm}^{-2}$

$j_{0, a n} \quad$ anodic exchange current density $/ \mathrm{A} \mathrm{cm}^{-2}$

$j_{0, \text { cat }} \quad$ cathodic exchange current density / $\mathrm{A} \mathrm{cm}^{-2}$

$k \quad$ isentropic coefficient of the ideal gas

$l \quad$ cell layer thickness $/ \mathrm{m}$

LHV low heating value / $\mathrm{W}$

$M \quad$ molecular weight of species i $/ \mathrm{g} \mathrm{mol}^{-1}$

I $\underline{M a} \quad$ Mach number

$n_{\text {cells }} \quad$ total number of tubular cells inside the stack $(=88)$

Formatted: Font: Not Italic

$N \quad$ total number of discretised steps for solving the 1D cell domain

NG abbreviation for natural gas

$n_{i} \quad$ molar flow of species $i / \mathrm{mol} \mathrm{s}^{-1}$

$\mathrm{p} \quad$ absolute pressure / $\mathrm{Pa}$

$Q_{c o m b} \quad$ heat generated from the combustion of exhaust $\mathrm{H}_{2}$ and $\mathrm{CO}$ in the after-burner / W

$Q_{\text {evap }} \quad$ heat required to evaporate the liquid fuel in the tank / W

$Q_{\text {fuel }} \quad$ heat required to heat the fuel at the stack temperature $/ \bar{W}$

$Q_{\text {loss }} \ldots$ heat generated by irreversibilities of the stack polarisation / W

$Q_{\text {react }}$ heat generated by the oxidation of $\mathrm{H}_{2}$ and $\bar{C} \mathrm{O}$ inside the stack $/ \overline{\mathrm{W}}$

\section{$Q_{\text {ref }} \quad$ heat required by the reformer / W}

$Q_{\text {stack }} \quad$ overall internally heat produced by the stack / W

$r \quad$ mean pore radius $/ \mathrm{m}$

SLPM standard litre per minute

STCR steam-to-carbon ratio

$T_{\text {stack }} \quad$ operating temperature of the stack $/{ }^{\circ} \mathrm{C}$

$V \quad$ voltage / V

$w \quad$ interconnector width / $\mathrm{m}$ 
$W_{\text {th }} \quad$ available thermal power form the stack / W

$y_{i} \quad$ molar fraction of species $i$

$\varepsilon \quad$ electrode porosity

$\eta \quad$ cell overvoltage / V

$\lambda_{\text {air }} \quad$ air excess

gas density $\left(\mathrm{kg} \mathrm{m}^{-3}\right)$ / electronic resistivity (ohm m) in Eqs. 3-6

$\begin{array}{ll}\tau & \text { electrode tortuosity } \\ \omega & \text { ejector molar entrainment ratio }\end{array}$

Subscripts and superscripts

act activation

an anode

cat cathode

channel gas channel (outside the electrodes diffusion layer)

diff diffusion

ely electrolyte

eq equivalent

felt Ni-felt

int interface (electrode/electrolyte)

inter interconnector

| ohm _. . . ohmic

ox oxidant

pore electrode pore

recirc recirculation 
Formatted: Bullets and

Deleted: , F., ..., ...M.,

[1] S.C. Singhal, Solid State Ionics 2005, 135(1-4) 305-313.

[2] M. Gariglio, M., F. De Benedictis, M. Santarelli, M._Calì, G. Orsello,_Int. J. Hydrogen Energy 2009 34(10) 4661-4668.

[3] S.L. Douvartzides, F.A. Coutelieris, A.K. Demin, P.E. Tsiakaras, AIChE J. 2003, 49(1) $248-257$

[4] H. Shapouri, J.A. Duffield, M. Wang, U.S. Department of Agriculture, Office of the Chief Economist, Office of Energy Policy and New Uses, Agricultural Economic Report No. $\underline{8132002}$

[5] CONCAWE, EUCAR, JRC/IES, 2007, "Well-To-Wheels analysis of future automotive fuels and powertrains in the European context: Well-To-Wheels Report", http://ies.jrc.ec.europa.eu/uploads/media/WTW_Report_010307.pdf.

[6] D. Pimentel, T.W.Patzek, Natural Resources Research 2005, 14(1) 65-76.

[7] Y. Sun ${ }_{\gtrless}$ J._Cheng, Bioresour. Technol. 2002, 83(1) 1-11.

[8] P.W. Li, M.K. Chyu ${ }_{2 .}$.PPower Sources 2003, 124(2)_487-498.

[9] P. Costamagna, P. Costa V. Antonucci, Electrochim ${ }_{t}$ Acta 1998, 43(3-4) 375-394.

[10] P. Aguiar, ,C.S. Adjiman, N.P. Brandon, 2004, J.Power Sources 2004, 138(1-2) 120-136.

[11] R. Suwanwarangkul, E. Croiset, E. Entchev, S. Charojrochkul, S., M.D. Pritzker, M.W. Fowler, P.L. Douglas, S. Chewathanakup, H. Mahaudom, J. Power Sources 2006, 161(1), $308-322$.

[12] K. Tanaka, C. Wen, K. Yamada, Fuel 2000 79 1493-1507.

[13] H. Yakabe, M. Hishinuma, M. Uratani, Y. Matsuzaki, I. Yasuda J. Power Sources 2000 $86(1-2) 423-431$.

[14] F.N Cayan, S.R. Pakalapati, S.R., F. Elizalde-Blancas, I._Celik, I., J. Power Sources 2009, $192(2) 467-474$. 
[15] S.H. Chan, K.A. Khor, Z.T. Xia, J. Power Sources 2001, 93(1-2) 130-140.

[16] R. Suwanwarangkul, E. Croiset, M.W. Fowler, P.L. Douglas, E. Entchev, M.A. Douglas, J. Power Sources 2003, $122(1), 9-16$.

[17] R.B. Bird, W. E. Stewart; E.N. Lightfoot, Transport Phenomena, 2 ed. New York, Wiley, 2005.

[18] P. Costamagna, A. Selimovic, M. Del Borghi, G. Agnew, Chemical Engineering Journal 2004, 102(1), 61-69.

[19] E. Riensche, U. Stimming, G. Unverzagt, J. Power Sources 1998, 73(2) 251-256.

[20] E. Riensche, J. Meusinger, U. Stimming, G. Unverzagt, G., J. Power Sources 1998, 71(12) 306-314.

[21] F. Marsano, L. Magistri, A.F. Massardo, J. Power Sources 2004, 129,216-228.

[22] J. Milewski, A. Miller, J. Sałaciński, Int. J. Hydrogen Energy 2007, 32(6) 687-698.

[23] Campanari S., J. Power Sources 2001, 92(1-2) 26-34.

[24] J. Van herle, Y. Membrez, O. Bucheli, J. Power Sources 2004, 127(1-2) 300-312.

[25] Y. Yi, A.D. Rao, J. Brouwer, G.S. Samuelsen, J. Power Sources 2005, 144(1) 67-76.

[26] S. Gordon, B.J. McBride, Computer program for calculation of complex chemical equilibrium compositions and applications I. Analysis_1994 NASA Lewis Research Center, Cleveland.

[27] R.C. Reid, J.M. Prausnitz, T.K. Sherwood, The properties of gas and liquids 1977, McGraw-Hill, New York.

[28] Y.Zhu Y., W. Cai, C. Wen, Y. Li, J. Power Sources 2007, 173 437-449.

[29] Y. Zhu Y., W. Cai, Y. Li, C. Wen, J. Power Sources 2008 185 ( 2) 1122-1130.

[30] M.L. Ferrari, A. Traverso, L. Magistri, A.F. Massardo, J. Power Sources 2005, 149, 22-32.

[31] L.J. De Chant, Combined numerical/analytical perturbation solutions of the NavierStokes equations for aerodynamic ejector/mixer nozzle flows 1998, NASA Contractor Report 1998-207406.

Deleted: , pp.

Formatted

Formatted

Formatted

Formatted

Formatted

Formatted: Bullets and Nur ... [104]

Formatted

Deleted: Milewski, J., Miller, ... [106]

Formatted [107]

Deleted: 2004, "Biogas as a f ... [108]

Formatted $\quad \ldots$ [109]

Deleted: Y.,...A.D.,.........,.. ... [110]

Formatted

Deleted: Journal of Power Sources

Formatted

Deleted: S., ...B.J., 1994, “ ... [113]

Formatted

Deleted: " National Aerona

Deleted: R.C JM

Formatted

Deleted: "

Deleted: W.,...C.,

Formatted

Deleted: Y., 2007, "Fuel ejec ... [120]

Formatted

.. [121]

Deleted: Zhu, Y., Cai, W., Li ... [122]

Formatted

Formatted

[123]

Deleted: Marsano, F., Magist ... [124] [125]

Formatted $\ldots[126]$

Deleted: M.L.,...A.,...L.,..., ... [127]

Formatted

Deleted: 2005, "Influence of ... [129]

Formatted

Deleted: -

Formatted

Formatted

Formatted

Formatted 
[32] N. Laosiripojana, S. Assabumrungrat Y. Zhu Y., W. Cai, C. Wen, Y. Li, J. Power Sources 2007 163(2) 943-951.
Deleted: N.,

Formatted: English (U.K.)

Deleted: , S., 2007, "Catalytic steam

reforming of methane, methanol, and

ethanol over Ni/YSZ: The possible use of

these fuels in internal reforming SOFC", Journal of Power Sources

Formatted: Font: $12 \mathrm{pt}$

Formatted: Font: Not Bold 


\section{List of figures}

Figure 1 - Installation of the $5 \mathrm{~kW}$ Siemens Generator in Turbocare Spa......................................... 5

Figure 2 - Basic BoP design of the SOFC generator analysed ...................................................... 6

Figure 3 - Ohmic losses in the tubular cell ……………….............................................. 8

Figure 4 - Fuel and air flows along the tubular cell ............................................................. 11

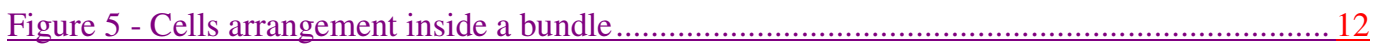

Figure 6 - Ejector scheme. 15

Figure 7 - Schematic sheet describing the iteration step for determining the molar composition of the anodic exhaust.

Figure 8 - Detailed flow-sheet with natural gas reference case...................................................... 19

Figure 9 - Detailed flow-sheet with ethanol feeding

Figure 10 - Comparison of the calculated Nernst voltage along the fuel channel (cell tube length) for both natural gas and ethanol feeding

Figure 11 - Equilibrium compositions of an ethanol/water mixture in a volumetric ratio 60/40 at different temperatures

Figure 12 - Schematic view of the $5 \mathrm{~kW}$ Generator to respect of the fuel and air feeding flows ..... 26

Figure 13 - Carbon boundary for the ethanol steam reforming ................................................... 27

Figure 14 - Ejector pressure increase during EtOH/H2O mixture feeding ........................................ 27

Figure 15 - Water stoichiometry in the NG/EtOH mixture reaching the stack ............................... 28

Figure 16 - Behaviour of stack voltage during the EtOH/H2O feeding experiment ....................... 29

Figure 17 - Comparison of string voltages during the EtOH/H2O feeding experiment ................... 29

Figure 18 - Stack voltage and current behaviour ........................................................................ 30

Figure 19 - Reformer temperature drop during the ethanol experiment ......................................... 30

Figure 20 - Generator temperatures behaviour during the ethanol experiment ................................ 30

Figure 21 - Generator electrical AC efficiency behaviour during the EtOH experiment .................. 31

\section{List of tables}

Table 1 - Parameters for the cell electrochemical model

Table 2 - Molar compositions of the recirculated flow entrained by the ejector and total steam fraction recirculated normalised to the primary flow entering the ejector itself.

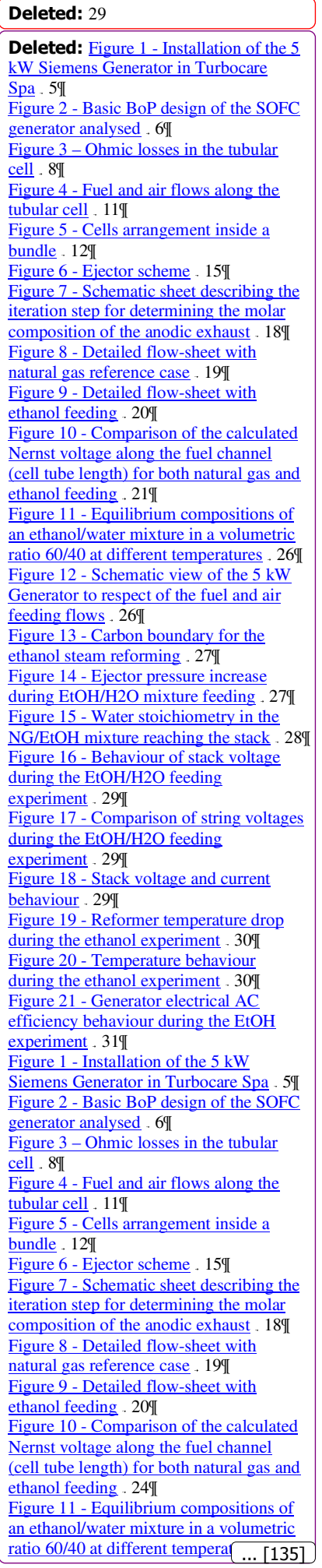




$$
n_{H_{2}, i+1}=n_{H_{2}, i}-I_{H_{2}, i}=n_{H_{2}, i}-\frac{3 / 4 \cdot\left(I_{C E L L} / N\right)}{2 \cdot F}
$$

$$
\begin{gathered}
n_{\mathrm{H}_{2} \mathrm{O}, i+1}=n_{\mathrm{H}_{2} \mathrm{O}, i}+\frac{3 / 4 I_{C E L L L}}{2 \cdot F} \\
n_{C O, i+1}=n_{C O, i}-\left(I_{C E L L} / N-I_{H_{2}, i}\right)=n_{C O, i}-\frac{1 / 4 I_{C E L L}}{2 F}
\end{gathered}
$$

$$
n_{\mathrm{CO}_{2}, i+1}=n_{\mathrm{CO}_{2}, i}+\frac{1 / 4 I_{C E L L}}{2 \cdot F}
$$

$$
n_{O_{2}, i+1}=n_{O_{2}, i}-\frac{I_{C E L L}}{4 \cdot F} \quad(26)
$$
defined, Line spacing: single, Adjust space between Latin and Asian text, Adjust space between Asian text and numbers

Page 11: [3] Deleted $\quad$ andrea $\quad 3 / 6 / 2010$ 7:10:00 PM

$$
\begin{aligned}
& \text { Page 13: [4] Deleted } \\
& \qquad\left\{\begin{array}{l}
T_{\text {stack }} \cdot \Delta S_{\text {stack }}=\Delta H_{\text {stack }}-\Delta G_{\text {stack }} \\
Q_{\text {loss }}=I_{\text {stack }} \cdot\left(\frac{\Delta G_{\text {fuel }(H 2, C O)}^{\text {ox }}\left(T_{\text {stack }}, y_{\text {fuel }}\right)}{2 \cdot F}-V(I)\right)
\end{array}\right.
\end{aligned}
$$

Page 13: [5] Deleted andrea 3/20/2010 1:16:00 PM is linked to the thermal balance of the stack 
$\lambda_{\text {air }}=\frac{Q_{\text {stack }}+Q_{\text {ref }}+Q_{\text {fuel }}}{n_{\text {air }, \text { stech }} \cdot \bar{c}_{p, \text { air }}\left(T_{\text {stack }}-T_{\text {air,inlet }}\right)}$

Page 13: [7] Formatted andrea

3/20/2010 1:25:00 PM

Justified, Don't adjust right indent when grid is defined, Line spacing: Double, Don't adjust space between Latin and Asian text, Don't adjust space between Asian text and numbers

Page 13: [8] Deleted
through the top area of the generator
$\begin{gathered}\text { Page 13: [9] Deleted } \\ \text { before reaching the cells. }\end{gathered}$

Page 13: [10] Formatted

andrea

3/29/2010 4:11:00 PM

List Paragraph, Justified, Don't adjust right indent when grid is defined, Line spacing:

Double, Outline numbered + Level: 2 + Numbering Style: 1, 2, 3, . + Start at: $1+$

Alignment: Left + Aligned at: $18 \mathrm{pt}+$ Tab after: $0 \mathrm{pt}+$ Indent at: $36 \mathrm{pt}$, Don't

Page 20: [11] Deleted andrea 3/27/2010 6:36:00 PM

Nevertheless, the polarisation of the stack when ethanol fuel is feeding the generator is

actually slightly higher than for NG. Under the hypothesis of a proper reforming of ethanol, the fuel quantity in both feeding cases is such as to preserve the overall $\mathrm{H}_{2}$ equivalents entering the system. Thus, the Nernst voltage of the stack should not be affected significantly. This aspect has been analysed in more detail by drawing the Nernst voltage along the fuel channel (which corresponds to the cell tube length) for both fuel cases.

$$
S T C R=\frac{y_{\mathrm{H}_{2} \mathrm{O}} \cdot n_{\text {an,recirc }}}{n_{\text {fuel }}+y_{\mathrm{CO}} \cdot n_{\text {an,recirc }}} .
$$

Page 22: [13] Deleted andrea

3/27/2010 10:34:00 PM

For the fuels considered here, $t$ 


\begin{tabular}{|c|c|}
\hline \multirow[t]{3}{*}{ Page 24: [15] Deleted } & andrea \\
\hline & $I_{T O T}$ \\
\hline & $F U=\frac{2 F}{n_{H_{2}, C O}^{C H_{4}}}$ \\
\hline
\end{tabular}

Page 24: [16] Deleted defines

Page 24: [16] Deleted

andrea

3/27/2010 11:10:00 PM that is

andrea

3/27/2010 11:10:00 PM andrea

3/27/2010 11:10:00 PM in which
Page 24: [16] Deleted achieves andrea

3/27/2010 11:14:00 PM andrea

3/27/2010 11:15:00 PM , and

\section{Page 24: [16] Deleted}

andrea

3/27/2010 11:14:00 PM an

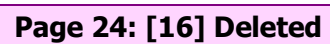




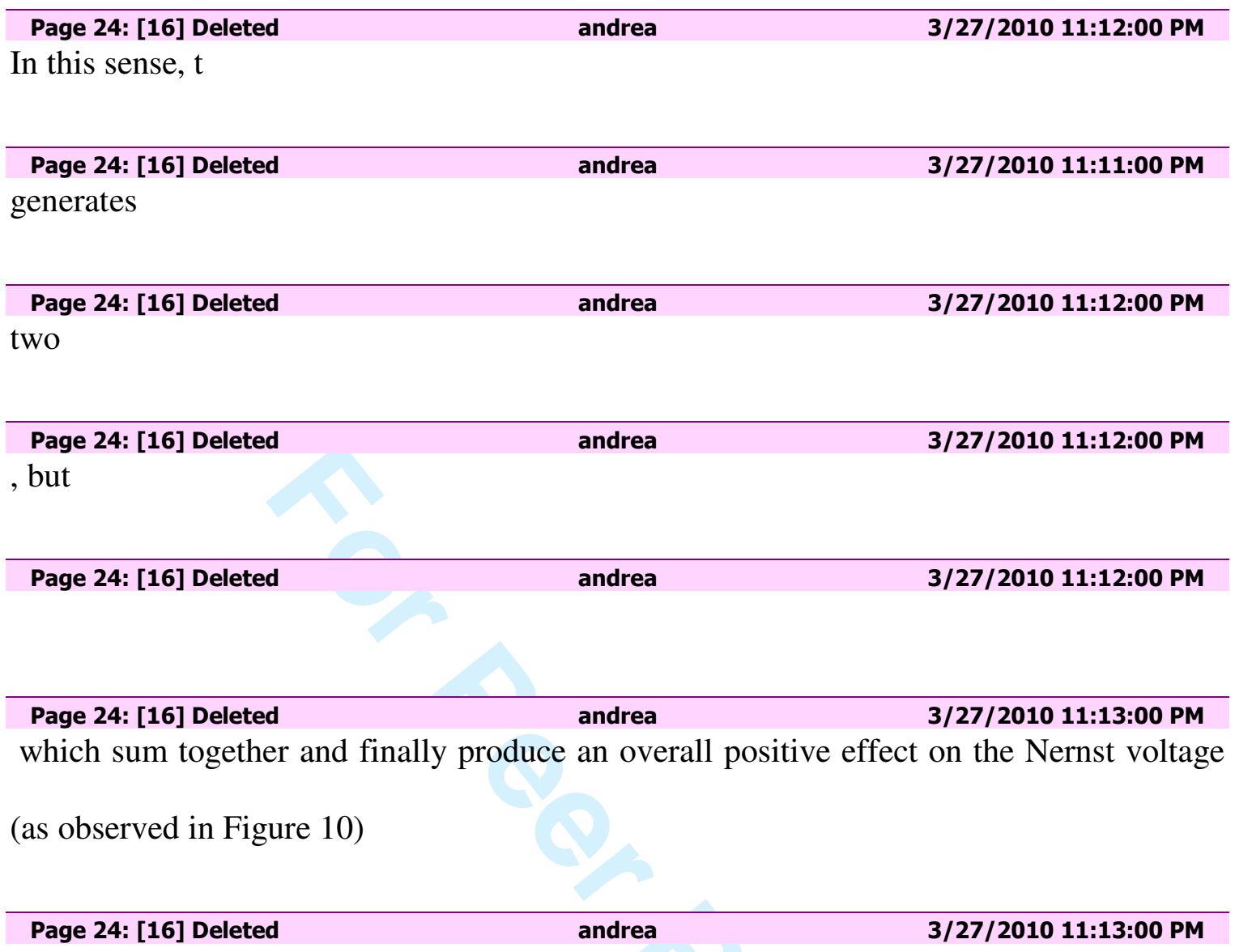

Figure 10 - Comparison of the calculated Nernst voltage along the fuel channel (cell tube length) for both natural gas and ethanol feeding

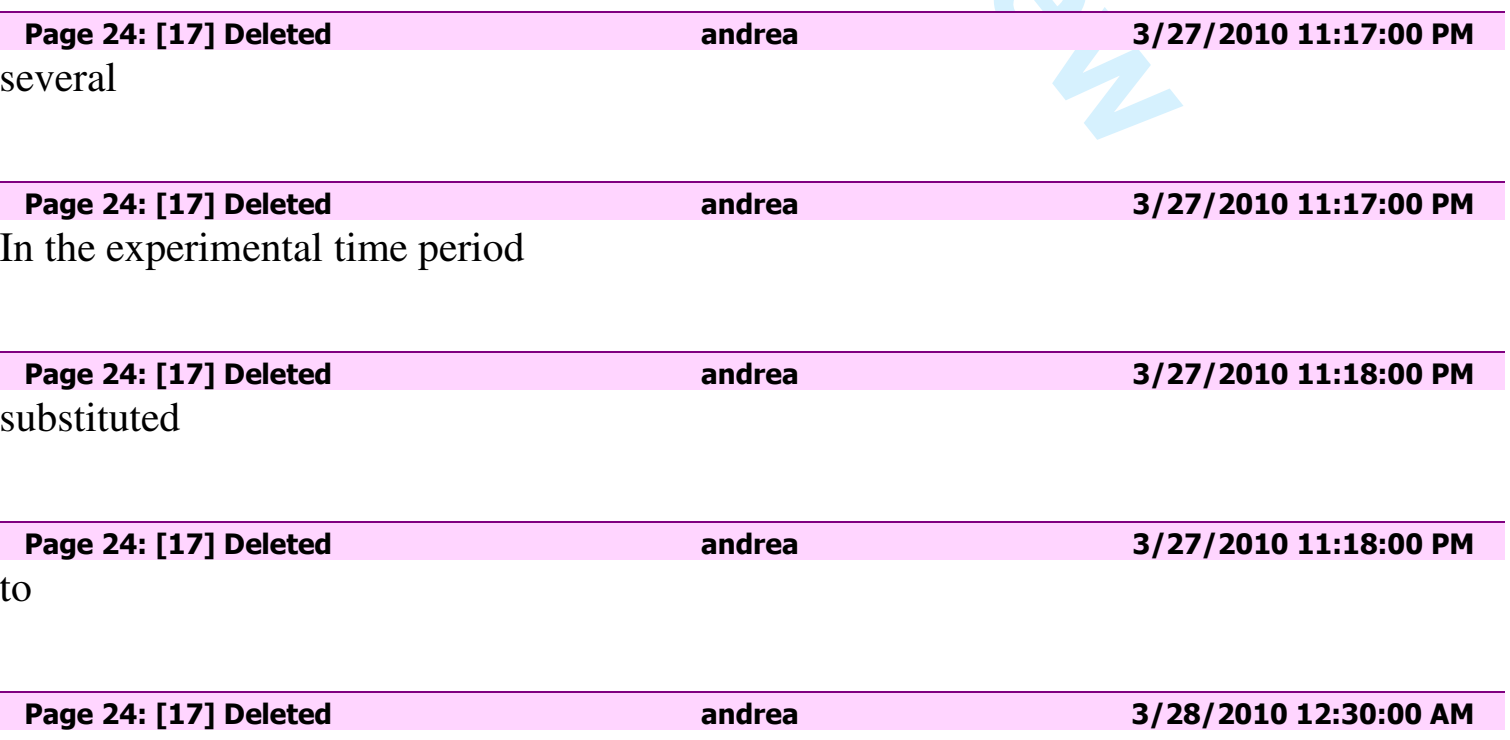


NG flow

Page 24: [17] Deleted andrea
According to the standard procedure employed while operating the generator,

\begin{tabular}{|c|c|c|}
\hline Page 24: [17] Deleted & andrea & $3 / 28 / 201012: 30: 00$ AM \\
\hline
\end{tabular}

\begin{tabular}{|c|c|c|}
\hline Page 2 & andrea & $3 / 28 / 201012: 32: 00$ AM \\
\hline
\end{tabular}

3/28/2010 12:32:00 AM

determined

Page 24: [17] Deleted $\quad$ andrea
upon

\begin{tabular}{|c|c|c|}
\hline Page 24: [17] Deleted & andrea & $3 / 28 / 201012: 31: 00 \mathrm{AM}$ \\
\hline $\mathrm{DC}$ & $\mathrm{n}-\mathrm{s}$ & \\
\hline Page 24: [17] Deleted & andrea & $3 / 28 / 201012: 33: 00 \mathrm{AM}$ \\
\hline load & 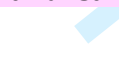 & \\
\hline
\end{tabular}

Page 24: [17] Deleted andrea

3/27/2010 11:19:00 PM

, FU of the generator, and type of fuel entering it.

For simplicity, we refer here just to methane as a fuel (even if the real fuel is natural gas); the methane

Page 24: [17] Deleted
is thus

\begin{tabular}{|c|c|c|}
\hline \multirow{3}{*}{ Page 24: [18] Deleted } & andrea & 3/6/2010 8:04:00 PM \\
\hline & $\left(I_{\text {stack }} / 2\right) \cdot n_{\text {cells }}$ & \multirow{2}{*}{$(37)$} \\
\hline & $2 \cdot F \quad \overline{H_{2, e q}^{r e f o r \min g} \cdot F U}$ & \\
\hline Page 24: [18] Deleted & andrea & $3 / 28 / 201012: 34: 00$ AM \\
\hline
\end{tabular}


Two factors can modify Eq. 37: i) the effective fuel consumption (FC), which is greater than the FU, since some air leakage occurs inside the stack (the denominator of Eq. 37 should in fact be FC instead of FU); ii) the stack NG flow is not pure methane, thus the effective inlet molar composition of the fuel gas should be taken into account to calculate the exact number of $\mathrm{H}_{2}$-equivalents. The modifications due to these two effects are relatively low, because the air leaks inside the generator are rather low and the relative error committed in considering just methane as the fuel flow is lower than $1 \%$ when evaluating $H_{2, e q}$.

\section{Page 24: [18] Deleted} number andrea

3/28/2010 12:36:00 AM satisfy a certain stack current of the generator.

$$
\text { Page 24: [18] Deleted }
$$$$
\text { andrea }
$$

andrea andrea andrea 3/28/2010 12:38:00 AM Subscript
Page 25: [19] Formatted Subscript , upon 

an

Page 25: [20] Deleted
mixture,

\section{Page 25: [20] Deleted} andrea 3/28/2010 6:53:00 PM always

Page 25: [20] Deleted andrea 3/28/2010 12:39:00 AM an overall fuel mixture that was able to provide the stack with the same amount of equivalent reactive moles of $\mathrm{H}_{2}$ of the nominal NG flow, while undertaking a full steamreforming

\begin{tabular}{|c|c|c|}
\hline Page 25: [21] Deleted & andrea & 3/6/2010 8:13:00 PM \\
\hline Taking & & \\
\hline Page 25: [21] Deleted & andrea & $3 / 8 / 201010: 42: 00$ AM \\
\hline
\end{tabular}

\begin{tabular}{lll}
\hline Page 25: [21] Deleted & andrea & 3/28/2010 12:40:00 AM \\
, we hav & & \\
\hline Page 25: [21] Deleted & andrea & $3 / 28 / 2010$ 12:40:00 AM \\
\hline
\end{tabular}

\section{Page 25: [22] Formatted} andrea 3/8/2010 10:41:00 AM English (U.K.), Lowered by $6 \mathrm{pt}$

\begin{tabular}{|c|c|c|}
\hline Page 25: [22] Formatted & andrea & 3/6/2010 8:12:00 PM \\
\hline \multicolumn{3}{|l|}{ English (U.K.) } \\
\hline Page 25: [22] Formatted & andrea & $3 / 8 / 201010: 41: 00$ AM \\
\hline \multicolumn{3}{|l|}{ Formatted } \\
\hline Page 25: [23] Deleted & andrea & 3/6/2010 8:12:00 PM \\
\hline $\mathrm{CH}_{4}$ & $+\mathrm{H}_{2} \mathrm{O} \rightarrow 3 \mathrm{H}_{2}+\mathrm{CO},\left(\Delta \mathrm{H}_{\text {react }}(298 \mathrm{~K})\right.$ & $\left.=206.33 \mathrm{~kJ} \mathrm{~mol} \mathrm{~m}^{-1}\right)$ \\
\hline
\end{tabular}


$\mathrm{C}_{2} \mathrm{H}_{5} \mathrm{OH}+\mathrm{H}_{2} \mathrm{O} \rightarrow 4 \mathrm{H}_{2}+2 \mathrm{CO},\left(\Delta \mathrm{H}_{\text {react }}(298 \mathrm{~K})=256.79 \mathrm{~kJ} \mathrm{~mol}^{-1}\right)$.

Page 25: [23] Deleted $\quad$ andrea
that a

\begin{tabular}{lll}
\hline Page 25: [23] Deleted & andrea & 3/8/2010 10:43:00 AM \\
, when fully steam-reformed & &
\end{tabular}

Page 25: [24] Deleted
moles

\begin{tabular}{lll}
\hline Page 25: [24] Deleted & andrea & $3 / 8 / 2010$ 10:44:00 AM \\
per mole of steam-reformed & & \\
& & $3 / 8 / 2010$ 10:44:00 AM
\end{tabular}

Page 25: [24] Deleted

andrea

$3 / 28 / 2010$ 12:42:00 AM

is

Page 25: [24] Deleted $\quad$ andrea
ratio

Page 25: [24] Deleted $\quad$ andrea
$\begin{aligned} & \text { es } \\ & \text { 3/8/2010 10:44:00 AM }\end{aligned}$

Page 25: [24] Deleted $\quad$ andrea $3 / 28 / 2010$ 12:42:00 AM

, thus maintaining the number of $\mathrm{H}_{2}$-equivalents constant.

\begin{tabular}{ll}
\hline Page 25: [25] Deleted & andrea \\
\hline
\end{tabular}

Page 25: [25] Deleted

andrea

3/28/2010 6:54:00 PM in-stack

Page 25: [26] Deleted

andrea

3/28/2010 6:54:00 PM

imposed 

to be

Page 25: [26] Deleted
reforming

\begin{tabular}{|c|c|c|}
\hline Page 25: [26] Deleted & andrea & $3 / 28 / 2010$ 6:55:00 PM \\
\hline
\end{tabular}

\begin{tabular}{|c|c|c|}
\hline Page 25: [26] Deleted & andrea & 3/28/2010 6:55:00 PM \\
\hline
\end{tabular}

\begin{tabular}{|c|c|c|}
\hline Page 25: [26] Deleted & andrea & $3 / 28 / 2010$ 6:55:00 PM \\
\hline
\end{tabular}

Page 25: [26] Deleted $\quad$ andrea
feeding

\begin{tabular}{ll}
\hline Page 25: [26] Deleted & andrea \\
aspect &
\end{tabular}
Page 25: [26] Deleted andrea 3/28/2010 12:44:00 AM fully evident in

Page 25: [26] Deleted $\quad$ andrea $\quad 3 / 28 / 2010$ 12:44:00 AM

Page 25: [26] Deleted andrea

3/28/2010 7:24:00 PM 4.7 instead

Page 25: [26] Deleted $\quad$ andrea
of

\begin{tabular}{|c|c|c|}
\hline Page 25: [26] Deleted & andrea & $3 / 28 / 201012: 44: 00$ AM \\
\hline with NG & & \\
\hline Page 25: [27] Deleted & andrea & $3 / 28 / 201012: 45: 00$ AM \\
\hline
\end{tabular}

In terms of the ethanol fuel mixture 


\section{, $\mathrm{t}$}

Page 25: [27] Deleted

andrea

$3 / 28 / 2010$ 12:47:00 AM chosen

\begin{tabular}{|c|c|c|}
\hline Page 25: [27] Deleted & andrea & $3 / 28 / 201012: 47: 00$ AM \\
\hline \multicolumn{3}{|l|}{ with respect to } \\
\hline Page 25: [27] Deleted & andrea & $3 / 28 / 20107: 25: 00 \mathrm{PM}$ \\
\hline \multicolumn{3}{|l|}{ carbo } \\
\hline Page 30: [28] Deleted & andrea & 3/6/2010 8:54:00 PM \\
\hline \multicolumn{3}{|l|}{ long } \\
\hline Page 30: [28] Deleted & andrea & 3/6/2010 8:54:00 PM \\
\hline \multicolumn{3}{|l|}{, but } \\
\hline Page 30: [28] Deleted & andrea & 3/6/2010 8:55:00 PM \\
\hline the value & & \\
\hline Page 30: [28] Deleted & andrea & 3/6/2010 8:53:00 PM \\
\hline
\end{tabular}

Page 30: [29] Deleted

andrea

3/27/2010 11:26:00 PM decrease

Page 30: [29] Deleted

andrea

3/27/2010 11:26:00 PM

$\mathrm{S}$

Page 30: [30] Formatted

andrea

3/27/2010 11:26:00 PM

English (U.K.)

\begin{tabular}{lcc}
\hline Page 30: [30] Formatted & andrea & $\mathbf{3 / 2 7 / 2 0 1 0 ~ 1 1 : 2 6 : 0 0 ~ P M ~}$ \\
English (U.K.) & & \\
\hline $\begin{array}{l}\text { Page 30: [30] Formatted } \\
\text { Subscript }\end{array}$ & andrea & $\mathbf{3 / 2 8 / 2 0 1 0 ~ 7 : 3 8 : 0 0 ~ P M}$ \\
\hline Page 30: [30] Formatted & andrea & $\mathbf{3 / 2 7 / 2 0 1 0 ~ 1 1 : 3 0 : 0 0 ~ P M ~}$ \\
English (U.K.) & & \\
\hline Page 30: [31] Deleted & andrea & $\mathbf{3 / 2 8 / 2 0 1 0 ~ 7 : 3 8 : 0 0 ~ P M ~}$
\end{tabular}

and also 

ly the

\section{Page 30: [33] Deleted} andrea

3/27/2010 11:30:00 PM

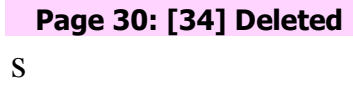


that happens

\begin{tabular}{lcc}
\hline $\begin{array}{l}\text { Page 30: [34] Deleted } \\
\text { therefore }\end{array}$ & andrea & 3/27/2010 11:28:00 PM \\
& & $3 / 29 / 2010$ 4:05:00 PM \\
\hline Page 30: [35] Deleted & andrea & \\
\hline Page 30: [35] Deleted & - & $3 / 29 / 2010$ 4:05:00 PM \\
& Temperature
\end{tabular}

Page 30: [36] Deleted

andrea

3/6/2010 8:55:00 PM also

Page 30: [36] Deleted

andrea

3/27/2010 11:33:00 PM

since this is the parameter managing the stack temperature.

\begin{tabular}{lll}
\hline $\begin{array}{l}\text { Page 30: [36] Deleted } \\
\text { behaves }\end{array}$ & andrea & 3/27/2010 11:34:00 PM \\
& \\
\hline Page 30: [36] Deleted & andrea & $3 / 27 / 2010$ 11:36:00 PM
\end{tabular}
and the reformer is thermally integrated into the stack,

Page 30: [36] Deleted

andrea

3/27/2010 11:35:00 PM

it makes sense that the

Page 30: [36] Deleted

andrea

3/27/2010 11:23:00 PM

should increase

Page 30: [36] Deleted

andrea

3/27/2010 11:23:00 PM

increased

\begin{tabular}{|c|c|c|}
\hline Page 30: [36] Deleted & andrea & $3 / 28 / 2010$ 7:41:00 PM \\
\hline \multicolumn{3}{|l|}{ Actually, t } \\
\hline Page 30: [36] Deleted & andrea & 3/6/2010 8:58:00 PM \\
\hline \multicolumn{3}{|l|}{ SO } \\
\hline Page 30: [36] Deleted & andrea & 3/6/2010 8:16:00 PM \\
\hline
\end{tabular}


stoichs

Page 31: [37] Deleted

andrea

3/28/2010 7:49:00 PM

In Figure 21, it is also interesting to observe how the inlet reformer temperature behaves similarly to that of the after-burner. The reformer temperature is governed by the fuel inlet temperature and the anodic exhaust temperature. If we consider the fuel inlet temperature to be constant, the anodic exhaust temperature is the one really affecting and governing that of the inlet reformer zone. We should also consider that the anodic exhaust has basically the same temperature of the stack at the upper region. That is why there is a correlation between the stack upper temperature and the after-burner temperature. Thus, we can conclude that the latter temperature depends on what comes from the stack in terms of anodic exhaust, and the observed matching trend between the inlet reformer and after-burner zone temperatures finds its explanation. Of course a gap subsists between the two, and it is due to the combustion taking place in the after-burner.

\section{Figure 21 - After-burner and stack temperature behaviour}

Page 31: [38] Deleted andrea 3/27/2010 5:59:00 PM

The local FU has been evaluated for both fuel feeding cases and as related to stack performances.

Page 31: [39] Deleted

andrea

3/27/2010 6:03:00 PM

One issue to note is that with respect to the current system design,

Page 35: [40] Deleted

andrea

3/8/2010 1:03:00 PM

S.C., 2000, “Advances in solid oxide fuel cell technology", Solid State Ionics, 135 (1-

4) 305-313.

Page 35: [41] Change

andrea

Formatted Bullets and Numbering 
Font: Bold

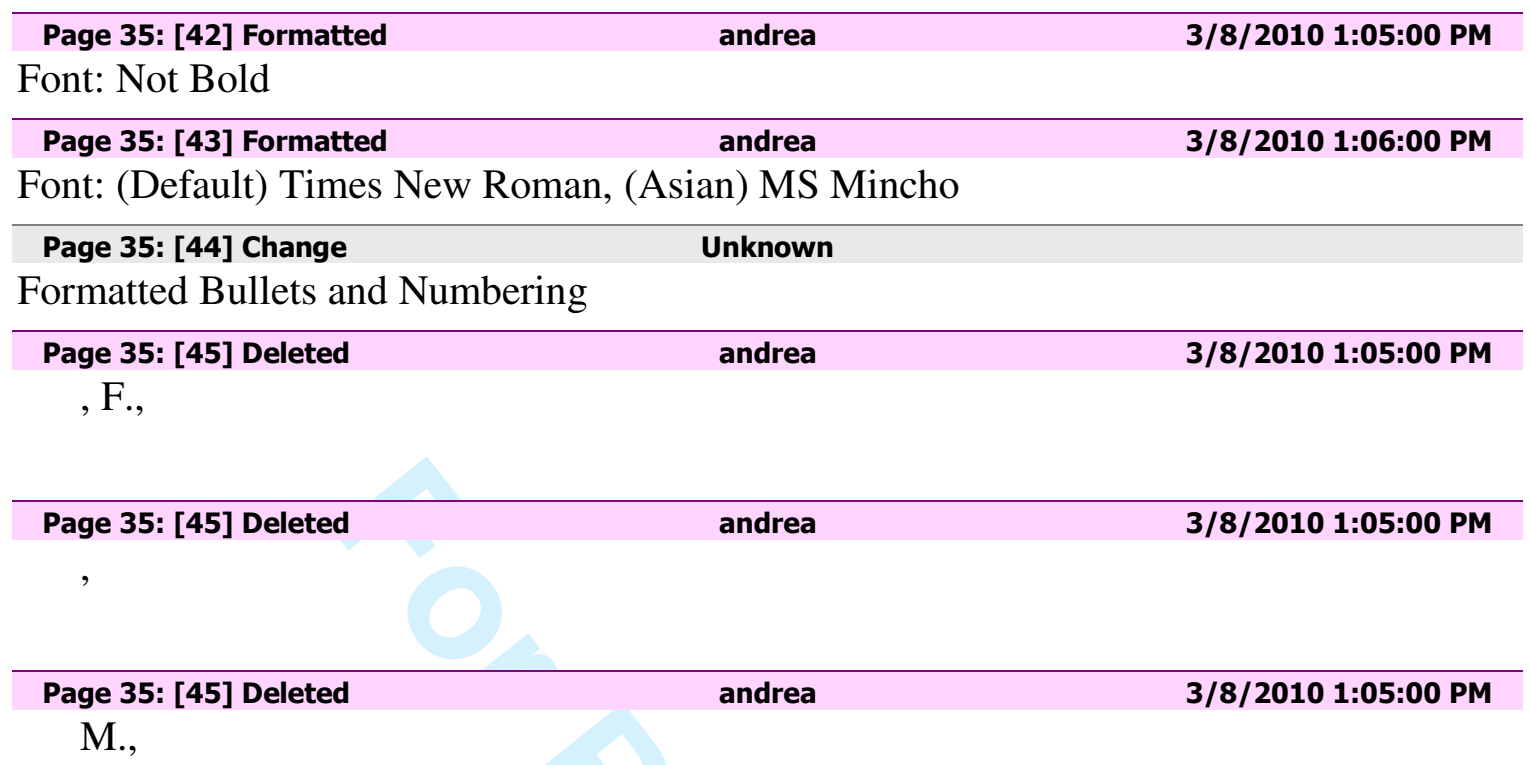

Page 35: [46] Formatted

andrea

3/8/2010 1:07:00 PM

Font: 12 pt, Italic, English (U.K.), Do not check spelling or grammar

\begin{tabular}{|c|c|c|}
\hline Page 35: [47] Formatted & andrea & 3/8/2010 1:06:00 PM \\
\hline Font: Bold & & \\
\hline Page 35: [48] Deleted & andrea & 3/8/2010 1:06:00 PM \\
\hline
\end{tabular}

\section{Page 35: [49] Formatted}

Font: Not Bold andrea

andrea

3/8/2010 1:06:00 PM Page 35: [50] Formatted

French (France)

Page 35: [51] Deleted S.L.

andrea

3/8/2010 1:07:00 PM

3/8/2010 1:07:00 PM

andrea

3/8/2010 1:07:00 PM 


\begin{tabular}{lll}
\hline Page 35: [52] Deleted & andrea & 3/8/2010 1:07:00 PM
\end{tabular}

\begin{tabular}{|c|c|c|}
\hline Page 35: [53] Formatted & andrea & 3/8/2010 1:07:00 PM \\
\hline French (France) & & \\
\hline
\end{tabular}

\begin{tabular}{|c|c|c|}
\hline Page 35: [54] Formatted & andrea & 3/8/2010 1:08:00 PM \\
\hline
\end{tabular}

\begin{tabular}{ll}
\hline Page 35: [55] Formatted & andrea \\
Font: Bold &
\end{tabular}

Page 35: [56] Deleted
"Fuel Options for solid oxide fuel cells: a thermodynamic analysis", AIChE Journal,

\begin{tabular}{lll}
\hline Page 35: [57] Formatted & andrea & $3 / 8 / 2010$ 1:07:00 PM \\
French (France) & & \\
\hline Page 35: [58] Formatted & andrea & $3 / 8 / 2010$ 1:08:00 PM \\
Font: Not Bold & & $3 / 8 / 2010$ 1:08:00 PM \\
\hline $\begin{array}{l}\text { Page 35: [59] Deleted } \\
\text { H., }\end{array}$ & andrea &
\end{tabular}

Page 35: [59] Deleted $\quad$ andrea
J.A.,

\begin{tabular}{|c|c|c|}
\hline Page 35: [59] Deleted & andrea & 3/8/2010 1:08:00 PM \\
\hline
\end{tabular}

Page 35: [60] Formatted $\quad$ andrea
Font: Bold

Page 35: [61] Deleted $\quad$ andrea $\quad 3 / 8 / 2010$ 1:09:00 PM

"The Energy Balance of Corn Ethanol: An Update", U.S. Department of Agriculture, Office of the Chief Economist, Office of Energy Policy and New Uses, Agricultural Economic Report No. 813

\begin{tabular}{lll}
\hline Page 35: [62] Formatted & andrea & $3 / 8 / 2010$ 1:12:00 PM \\
Font: Bold & & \\
\hline $\begin{array}{l}\text { Page 35: [63] Deleted } \\
\text { D., }\end{array}$ & andrea & $3 / 8 / 20101: 13: 00$ PM \\
\end{tabular}




\begin{tabular}{|c|c|c|}
\hline Page 35: [64] Formatted & andrea & 3/8/2010 1:14:00 PM \\
\hline \multicolumn{3}{|l|}{ Font: Italic } \\
\hline Page 35: [64] Formatted & andrea & 3/8/2010 1:13:00 PM \\
\hline \multicolumn{3}{|l|}{ Font: Bold } \\
\hline Page 35: [64] Formatted & andrea & 3/8/2010 1:13:00 PM \\
\hline \multicolumn{3}{|l|}{ Font: Not Bold } \\
\hline Page 35: [65] Deleted & andrea & 3/8/2010 1:13:00 PM \\
\hline Y., & & \\
\hline Page 35: [65] Deleted & andrea & 3/8/2010 1:14:00 PM \\
\hline
\end{tabular}

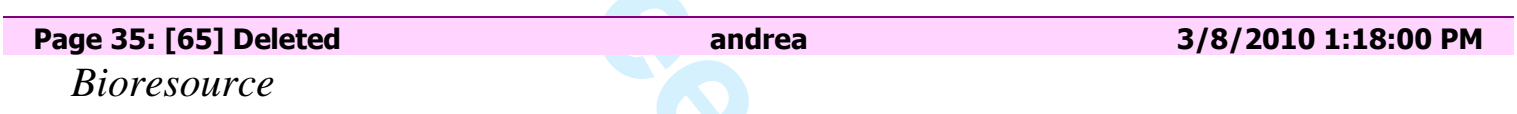

\section{Page 35: [66] Formatted}

Font: Italic andrea

andrea

andrea

andrea

andrea

3/8/2010 1:20:00 PM

3/8/2010 1:14:00 PM

3/8/2010 1:14:00 PM

3/8/2010 1:14:00 PM

3/8/2010 1:14:00 PM
Font: Not Bold

\begin{tabular}{|c|c|c|}
\hline Page 35: [68] Deleted & andrea & 3/8/2010 1:20:00 PM \\
\hline
\end{tabular}

\begin{tabular}{lll}
\hline Page 35: [68] Deleted & andrea & 3/8/2010 1:20:00 PM \\
, M.K., 2003, & &
\end{tabular}

Page 35: [68] Deleted $\quad$ andrea $\quad 3 / 8 / 2010$ 1:19:00 PM

"Simulation of the chemical/electrochemical reactions and heat/mass transfer for a tubular SOFC in a stack", Journal of 


\begin{tabular}{|c|c|c|}
\hline Page 35: [69] Formatted & andrea & 3/8/2010 1:19:00 PM \\
\hline \multicolumn{3}{|l|}{ Font: Not Bold } \\
\hline Page 35: [70] Formatted & andrea & 3/8/2010 1:19:00 PM \\
\hline \multicolumn{3}{|l|}{ English (U.K.) } \\
\hline Page 35: [71] Deleted & andrea & 3/8/2010 1:16:00 PM \\
\hline \multicolumn{3}{|l|}{ P., } \\
\hline Page 35: [71] Deleted & andrea & 3/8/2010 1:17:00 PM \\
\hline
\end{tabular}

\section{Page 35: [72] Formatted} Font: Italic andrea

3/8/2010 1:19:00 PM

\begin{tabular}{|c|c|c|}
\hline Page 35: [72] Formatted & andrea & 3/8/2010 1:17:00 PM \\
\hline \multicolumn{3}{|l|}{ Font: Italic, Italian (Italy) } \\
\hline Page 35: [73] Formatted & andrea & 3/8/2010 1:17:00 PM \\
\hline \multicolumn{3}{|c|}{ Font: Italic, Italian (Italy) } \\
\hline Page 35: [73] Formatted & andrea & 3/8/2010 1:17:00 PM \\
\hline \multicolumn{3}{|l|}{ Font: Bold } \\
\hline Page 35: [73] Formatted & andrea & 3/8/2010 1:16:00 PM \\
\hline \multicolumn{3}{|l|}{ Italian (Italy) } \\
\hline Page 35: [73] Formatted & andrea & 3/8/2010 1:17:00 PM \\
\hline \multicolumn{3}{|c|}{ Font: Not Bold, Italian (Italy) } \\
\hline Page 35: [73] Formatted & andrea & 3/8/2010 1:17:00 PM \\
\hline \multicolumn{3}{|l|}{ Italian (Italy) } \\
\hline Page 35: [74] Deleted & andrea & 3/8/2010 1:20:00 PM \\
\hline \multicolumn{3}{|l|}{ P., } \\
\hline Page 35: [74] Deleted & andrea & 3/8/2010 1:20:00 PM \\
\hline
\end{tabular}

Page 35: [74] Deleted $\quad$ andrea
N.P.,
cell. I: model-based steady-state performance", 
Font: Italic

\begin{tabular}{|c|c|c|}
\hline Page 35: [76] Formatted & andrea & 3/8/2010 1:21:00 PM \\
\hline \multicolumn{3}{|l|}{ Font: Bold } \\
\hline Page 35: [76] Formatted & andrea & 3/8/2010 1:21:00 PM \\
\hline \multicolumn{3}{|l|}{ Font: Not Bold } \\
\hline Page 35: [77] Deleted & andrea & $3 / 11 / 201011: 16: 00$ AM \\
\hline \multicolumn{3}{|l|}{ R., } \\
\hline Page 35: [77] Deleted & andrea & $3 / 11 / 2010$ 11:16:00 AM \\
\hline \multicolumn{3}{|l|}{ E., } \\
\hline Page 35: [77] Deleted & andrea & $3 / 11 / 2010$ 11:16:00 AM \\
\hline \multicolumn{3}{|l|}{ E., } \\
\hline Page 35: [77] Deleted & andrea & 3/11/2010 11:16:00 AM \\
\hline \multicolumn{3}{|l|}{ M.D., } \\
\hline Page 35: [77] Deleted & andrea & $3 / 11 / 2010$ 11:16:00 AM \\
\hline M.W., & 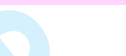 & \\
\hline Page 35: [77] Deleted & andrea & $3 / 11 / 201011: 16: 00 \mathrm{AM}$ \\
\hline
\end{tabular}

Page 35: [77] Deleted
P.L.,

\begin{tabular}{lcc} 
Page 35: [77] Deleted & andrea & $3 / 11 / 2010$ 11:16:00 AM \\
S., & & \\
& & \\
\hline Page 35: [77] Deleted & andrea & $3 / 11 / 2010$ 11:17:00 AM
\end{tabular}

, H., 2006, "Experimental and modeling study of solid oxide fuel cell operating with syngas fuel", Journal of Power Sources,

\begin{tabular}{|c|c|c|}
\hline Page 35: [78] Formatted & andrea & 3/11/2010 11:17:00 AM \\
\hline \multicolumn{3}{|l|}{ Font: Not Bold } \\
\hline Page 35: [79] Deleted & andrea & $3 / 11 / 2010$ 11:17:00 AM \\
\hline , & & \\
\hline Page 35: [79] Deleted & andrea & $3 / 11 / 2010$ 11:17:00 AM \\
\hline
\end{tabular}



turbine,

Font: Italic

\section{Page 35: [82] Formatted} andrea 3/11/2010 11:18:00 AM Font: Bold

\section{Page 35: [83] Formatted} andrea 3/11/2010 11:25:00 AM Font: Not Bold

Page 35: [84] Deleted andrea 3/11/2010 11:18:00 AM

, Evaluation and modelingof performance of anode-supported solid oxide fuel cell, Journal of Power Sources

\begin{tabular}{|c|c|c|}
\hline Page 35: [84] Deleted & andrea & 3/11/2010 11:18:00 AM \\
\hline 2000 & & \\
\hline Page 35: [85] Deleted & andrea & $3 / 11 / 201011: 20: 00$ AM \\
\hline F.N., & & \\
\hline Page 35: [85] Deleted & andrea & 3/11/2010 11:21:00 AM \\
\hline F., & & \\
\hline Page 35: [85] Deleted & andrea & 3/11/2010 11:21:00 AM \\
\hline Page 35: [85] Deleted & andrea & 3/11/2010 11:21:00 AM \\
\hline
\end{tabular}

Page 35: [85] Deleted andrea 3/11/2010 11:21:00 AM Journal of Power Sources 
S. H.,

\begin{tabular}{|c|c|c|}
\hline Page 36: [87] Deleted & andrea & 3/11/2010 11:22:00 AM \\
\hline K.A., & & \\
\hline Page 36: [87] Deleted & andrea & 3/11/2010 11:22:00 AM \\
\hline
\end{tabular}

Page 36: [87] Deleted andrea

3/11/2010 11:22:00 AM

"A complete polarization model of a solid oxide fuel cell and its sensitivity to the change of cell component thickness", Journal of Power Sources,

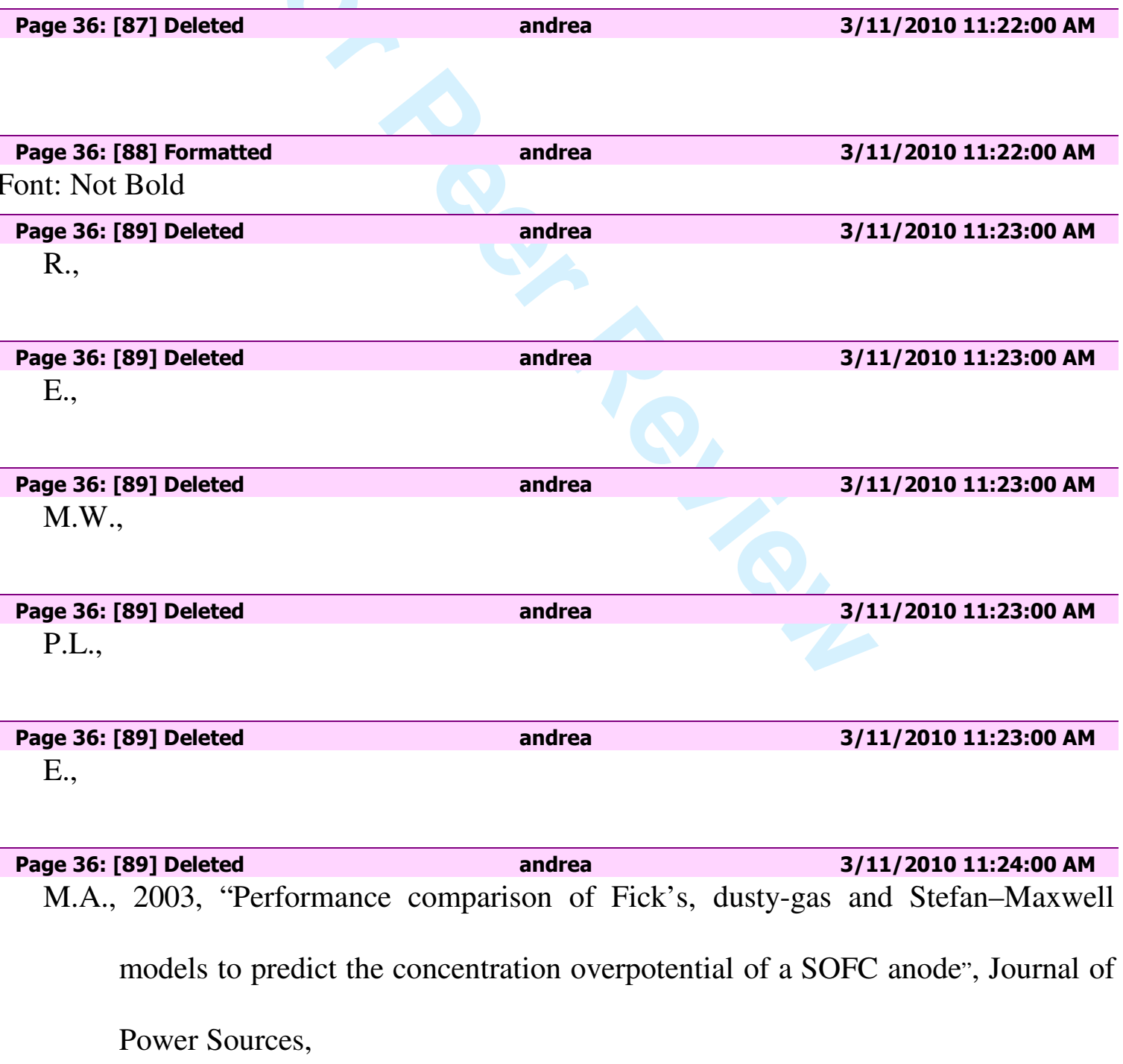


Page 36: [90] Formatted

Font: Not Bold andrea

andrea

andrea

andrea

3/11/2010 11:25:00 AM

Page 36: [93] Deleted

P.,

$3 / 11 / 2010$ 11:24:00 AM

3/11/2010 11:24:00 AM

3/11/2010 11:25:00 AM

\begin{tabular}{|c|c|c|}
\hline Page 36: [92] Formatted & andrea & 3/11/2010 11:25:00 AM \\
\hline Font: Bold & & \\
\hline Page 36: [93] Deleted & andrea & $3 / 11 / 201011: 25: 00$ AM \\
\hline
\end{tabular}

Page 36: [93] Deleted

andrea

3/11/2010 11:26:00 AM

A.,

andrea

3/11/2010 11:26:00 AM

\begin{tabular}{|c|c|c|}
\hline Page 36: [93] Deleted & andrea & 3/11/2010 11:26:00 AM \\
\hline Page 36: [93] Deleted & andrea & 3/11/2010 11:26:00 AM \\
\hline
\end{tabular}

Page 36: [93] Deleted

andrea

3/11/2010 11:26:00 AM

G., 2004, "Electrochemical model of the integrated planar solid oxide fuel cell (IP-

\section{SOFC)",}

\begin{tabular}{|c|c|c|}
\hline Page 36: [94] Formatted & andrea & 3/11/2010 11:45:00 AM \\
\hline Font: Not Bold & \\
\hline Page 36: [95] Deleted & andrea & 3/11/2010 11:33:00 AM \\
\hline \multicolumn{3}{|l|}{ E., } \\
\hline Page 36: [95] Deleted & andrea & 3/11/2010 11:33:00 AM \\
\hline U., & & \\
\hline Page 36: [95] Deleted & andrea & 3/11/2010 11:34:00 AM \\
\hline
\end{tabular}

Variation of process parameters", Journal of Power Sources

\begin{tabular}{lll}
\hline Page 36: [96] Formatted & andrea & 3/11/2010 11:34:00 AM \\
Font: Not Bold & & \\
\hline Page 36: [97] Deleted & andrea & $\mathbf{3 / 1 1 / 2 0 1 0 ~ 1 1 : 3 4 : 0 0 ~ A M ~}$ \\
E., & & \\
\hline
\end{tabular}




\begin{tabular}{l}
$\begin{array}{l}\text { Page 36: [97] Deleted } \\
\text { J., }\end{array}$ \\
$\begin{array}{l}\text { Page 36: [97] Deleted } \\
\text { U., }\end{array}$ \\
$\begin{array}{l}\text { Page 36: [97] Deleted } \\
\text { 1998, "Optimization of a } 200 \mathrm{~kW} \text { SOFC cogeneration power plant. Part II: variation }\end{array}$ \\
\hline \\
of the flowsheet", Journal of Power Sources
\end{tabular}

\begin{tabular}{|c|c|c|}
\hline Page 36: [98] Formatted & andrea & $3 / 11 / 2010$ 11:34:00 AM \\
\hline Font: Not Bold & & \\
\hline Page 36: [99] Formatted & andrea & $3 / 11 / 2010$ 11:37:00 AM \\
\hline Italian (Italy) & & \\
\hline
\end{tabular}

Page 36: [100] Formatted $\quad$ andrea $\quad 3 / 6 / 2010$ 7:50:00 PM

Numbered + Level: 1 + Numbering Style: $1,2,3, \ldots+$ Start at: 1 + Alignment: Left + Aligned at: $18 \mathrm{pt}+$ Tab after: $47.25 \mathrm{pt}+$ Indent at: $47.25 \mathrm{pt}$

\begin{tabular}{llr}
\hline Page 36: [101] Formatted & andrea & $\mathbf{3 / 1 1 / 2 0 1 0 ~ 1 1 : 3 7 : 0 0 ~ A M ~}$ \\
Font: Not Bold, Italian (Italy) & & \\
\hline $\begin{array}{l}\text { Page 36: [101] Formatted } \\
\text { Italian (Italy) }\end{array}$ & andrea & $\mathbf{3 / 1 1 / 2 0 1 0 ~ 1 1 : 3 7 : 0 0 ~ A M ~}$ \\
\hline $\begin{array}{l}\text { Page 36: [102] Formatted } \\
\text { English (U.K.) }\end{array}$ & andrea & $\mathbf{3 / 1 1 / 2 0 1 0 ~ 1 1 : 3 7 : 0 0 ~ A M}$ \\
\hline Page 36: [102] Formatted & andrea & $\mathbf{3 / 1 1 / 2 0 1 0 ~ 1 1 : 4 0 : 0 0 ~ A M ~}$ \\
Font: Bold & & \\
\hline Page 36: [103] Formatted & andrea & $3 / 6 / 2010$ 7:49:00 PM
\end{tabular}

Font: 12 pt, Not Bold, Font color: Auto, English (U.K.), Do not check spelling or grammar

\begin{tabular}{lcc}
\hline Page 36: [104] Change & andrea & $\mathbf{3 / 6 / 2 0 1 0 ~ 7 : 4 8 : 0 0 ~ P M}$ \\
Formatted Bullets and Numbering & & \\
\hline Page 36: [105] Formatted & andrea & $\mathbf{3 / 6 / 2 0 1 0 ~ 7 : 4 9 : 0 0 ~ P M}$
\end{tabular}

Font: 12 pt, Not Bold, Font color: Auto, English (U.K.), Do not check spelling or grammar

\begin{tabular}{|c|c|c|}
\hline Page 36: [105] Formatted & andrea & 3/11/2010 11:39:00 AM \\
\hline \multicolumn{3}{|l|}{ Font: Bold } \\
\hline Page 36: [105] Formatted & andrea & 3/6/2010 7:49:00 PM \\
\hline \multicolumn{3}{|c|}{ Font: 12 pt, English (U.K.), Do not check spelling or grammar } \\
\hline Page 36: [105] Formatted & andrea & 3/6/2010 7:49:00 PM \\
\hline \multicolumn{3}{|c|}{ Font: 12 pt, English (U.K.), Do not check spelling or grammar } \\
\hline Page 36: [106] Deleted & andrea & 3/6/2010 7:53:00 PM \\
\hline
\end{tabular}


Milewski, J., Miller, A., Sałaciński, J., 2007, “Off-design analysis of SOFC hybrid system”, International Journal of Hydrogen Energy, 32(6) 687-698.

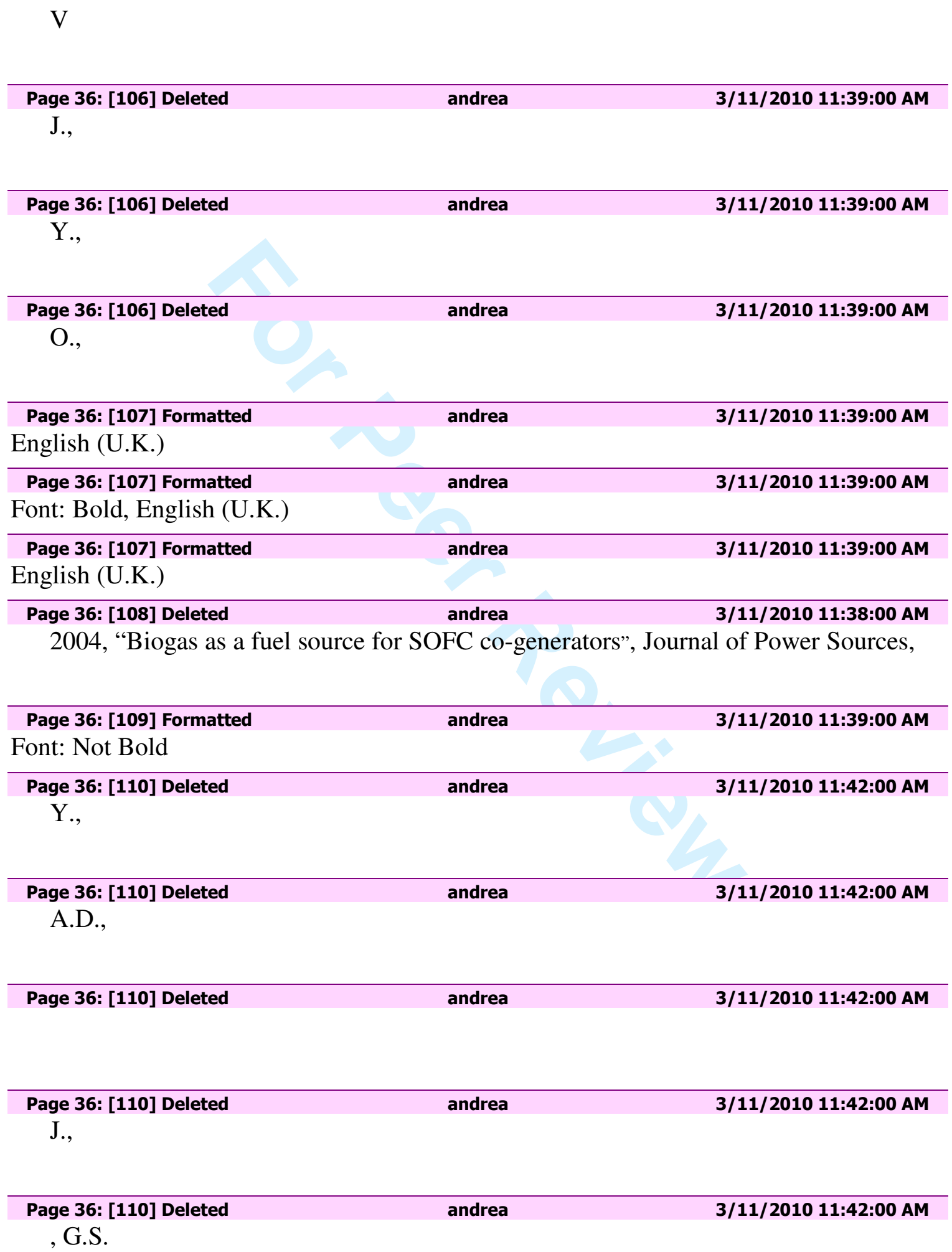
, G.S. 


\begin{tabular}{|c|c|c|}
\hline Page 36: [111] Formatted & andrea & $3 / 11 / 201011: 40: 00 \mathrm{AM}$ \\
\hline \multicolumn{3}{|l|}{ English (U.K.) } \\
\hline Page 36: [111] Formatted & andrea & 3/11/2010 11:40:00 AM \\
\hline \multicolumn{3}{|l|}{ Font: Bold, Not Italic } \\
\hline Page 36: [112] Formatted & andrea & 3/11/2010 11:40:00 AM \\
\hline \multicolumn{3}{|l|}{ Font: Not Bold } \\
\hline Page 36: [113] Deleted & andrea & $3 / 11 / 201011: 41: 00 \mathrm{AM}$ \\
\hline \multicolumn{3}{|l|}{ S., } \\
\hline Page 36: [113] Deleted & andrea & $3 / 11 / 201011: 41: 00$ AM \\
\hline \multicolumn{3}{|l|}{ B.J., 1994, “ } \\
\hline Page 36: [114] Formatted & andrea & 3/11/2010 11:33:00 AM \\
\hline Font: Bold & & \\
\hline Page 36: [115] Deleted & andrea & 3/11/2010 11:33:00 AM \\
\hline Page 36: [115] Deleted & andrea & $3 / 11 / 201011: 33: 00$ AM \\
\hline
\end{tabular}

andrea

3/11/2010 11:41:00 AM

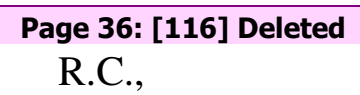


C.,

\section{Page 36: [119] Formatted}

andrea

3/11/2010 11:43:00 AM

Font: Bold, Not Italic

Page 36: [120] Deleted andrea

3/11/2010 11:43:00 AM

Y., 2007, "Fuel ejector design and simulation model for anodic recirculation SOFC system”, Journal of Power Sources

\section{Page 36: [121] Formatted}

Font: Not Bold andrea

3/11/2010 11:43:00 AM

Page 36: [122] Deleted andrea

3/11/2010 11:43:00 AM

Zhu, Y., Cai, W., Li, Y., Wen, C., 2008, “Anode gas recirculation behavior of a fuel ejector in hybrid solid oxide fuel cell systems: Performance evaluation in three operational modes”, Journal of Power Sources
Page 36: [123] Formatted

Font: Not Bold

\section{andrea}

andrea
3/7/2010 4:49:00 PM

3/7/2010 4:49:00 PM spacing: Double, Numbered + Level: $1+$ Numbering Style: 1, 2, 3, . + Start at: $1+$ Alignment: Left + Aligned at: $18 \mathrm{pt}+$ Tab after: $47.25 \mathrm{pt}+$ Indent at: $47.25 \mathrm{pt}$, Adjust $\mathrm{sp}$

Page 36: [125] Deleted andrea $\quad 3 / 6 / 2010$ 7:50:00 PM

Marsano, F., Magistri, L., Massardo, A.F., 2004, "Ejector performance influence on a solid oxide fuel cell anodic recirculation system", Journal of Power Sources, 129 216-228.

\section{Page 36: [126] Formatted}

Font: 12 pt, Not Bold andrea

3/7/2010 4:49:00 PM andrea

andrea
3/11/2010 11:44:00 AM

Font: 12 pt, Italian (Italy)
Page 36: [127] Deleted M.L.,

A., 


\begin{tabular}{|c|c|c|}
\hline Page 36: [127] Deleted & andrea & $3 / 11 / 201011: 44: 00$ AM \\
\hline L., & & \\
\hline Page 36: [127] Deleted & andrea & 3/11/2010 12:50:00 PM \\
\hline
\end{tabular}

Page 36: [128] Formatted

andrea

3/11/2010 11:44:00 AM

Font: 12 pt, Italian (Italy)

Page 36: [129] Deleted andrea

3/11/2010 11:44:00 AM

2005, "Influence of the anodic recirculation transient behaviour on the SOFC hybrid system performance", Journal of Power Sources

Page 36: [130] Formatted

Font: 12 pt, Italian (Italy) andrea andrea

Page 36: [130] Formatted

Font: 12 pt, Not Bold, Italian (Italy)
$3 / 11 / 2010$ 11:44:00 AM

3/11/2010 11:44:00 AM
3/11/2010 11:44:00 AM

Font: 12 pt, Italian (Italy)

andrea

andrea

3/11/2010 11:44:00 AM

Font: 12 pt, Italian (Italy) andrea

andrea
$3 / 11 / 2010$ 11:44:00 AM

English (U.K.)

Page 36: [133] Formatted

Numbered + Level: $1+$ Numbering Style: $1,2,3, \ldots+$ Start at: $1+$ Alignment: Left +

3/7/2010 4:49:00 PM Aligned at: $18 \mathrm{pt}+$ Tab after: $47.25 \mathrm{pt}+$ Indent at: $47.25 \mathrm{pt}$

Page 36: [134] Formatted $\quad$ andrea $\quad 3 / 7 / 2010$ 4:49:00 PM

Font: (Default) Times, (Asian) Times New Roman, 12 pt, English (U.K.), Do not check spelling or grammar

\begin{tabular}{lll}
\hline Page 36: [134] Formatted & andrea & 3/7/2010 4:49:00 PM
\end{tabular}

Font: (Default) Times, (Asian) Times New Roman, 12 pt, English (U.K.), Do not check spelling or grammar

Page 36: [134] Formatted andrea 3/7/2010 4:49:00 PM

Font: (Default) Times, (Asian) Times New Roman, 12 pt, English (U.K.), Do not check spelling or grammar

\begin{tabular}{|c|c|c|}
\hline Page 36: [134] Formatted & andrea & 3/11/2010 11:45:00 AM \\
\hline Font: Bold & & \\
\hline Page 36: [134] Formatted & andrea & 3/7/2010 4:49:00 PM \\
\hline
\end{tabular}

Font: (Default) Times, (Asian) Times New Roman, 12 pt, English (U.K.), Do not check spelling or grammar

\begin{tabular}{|c|c|c|}
\hline Page 36: [134] Formatted & andrea & 3/7/2010 4:49:00 PM \\
\hline Font: $12 \mathrm{pt}$ & & \\
\hline
\end{tabular}




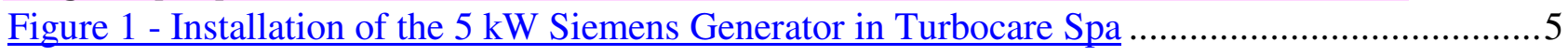

Figure 2 - Basic BoP design of the SOFC generator analysed .................................................6

Figure 3 - Ohmic losses in the tubular cell ................................................................... 8

Figure 4 - Fuel and air flows along the tubular cell ........................................................... 11

Figure 5 - Cells arrangement inside a bundle ................................................................... 12

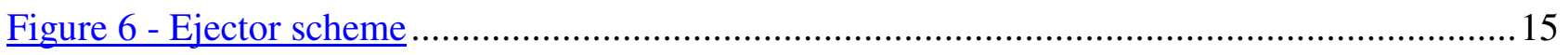

Figure 7 - Schematic sheet describing the iteration step for determining the molar composition of the anodic exhaust ............................................................................. 18

Figure 8 - Detailed flow-sheet with natural gas reference case ................................................. 19

Figure 9 - Detailed flow-sheet with ethanol feeding ............................................................ 20

Figure 10 - Comparison of the calculated Nernst voltage along the fuel channel (cell tube length) for both natural gas and ethanol feeding.

Figure 11 - Equilibrium compositions of an ethanol/water mixture in a volumetric ratio

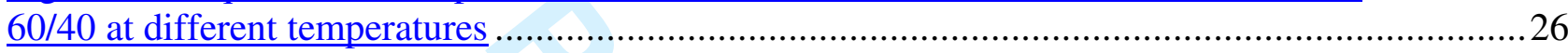

Figure 12 - Schematic view of the $5 \mathrm{~kW}$ Generator to respect of the fuel and air feeding

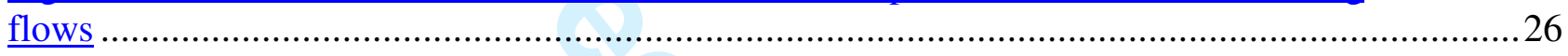

Figure 13 - Carbon boundary for the ethanol steam reforming .............................................227

Figure 14 - Ejector pressure increase during EtOH/H2O mixture feeding ................................227

Figure 15 - Water stoichiometry in the NG/EtOH mixture reaching the stack ...........................28

Figure 16 - Behaviour of stack voltage during the EtOH/H2O feeding experiment ......................29

Figure 17 - Comparison of string voltages during the EtOH/H2O feeding experiment ..................29

Figure 18 - Stack voltage and current behaviour ................................................................29

Figure 19 - Reformer temperature drop during the ethanol experiment ..................................3 30

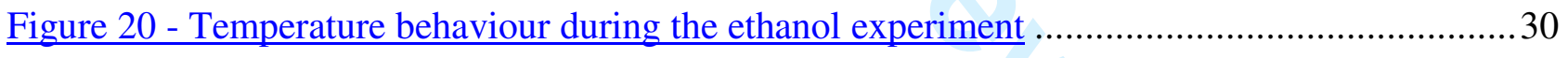

Figure 21 - Generator electrical AC efficiency behaviour during the EtOH experiment ................31

Figure 1 - Installation of the $5 \mathrm{~kW}$ Siemens Generator in Turbocare Spa ...................................5

Figure 2 - Basic BoP design of the SOFC generator analysed ............................................6

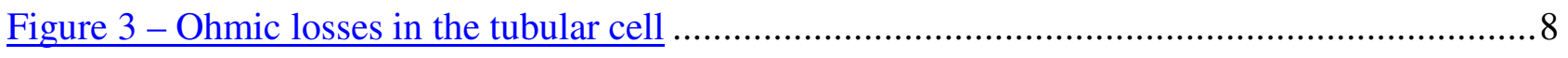

Figure 4 - Fuel and air flows along the tubular cell ......................................................... 11

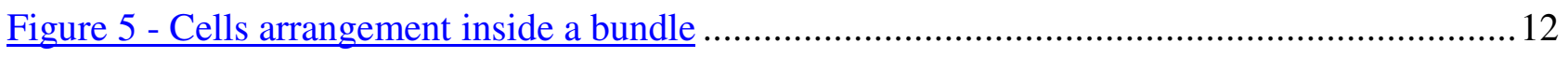

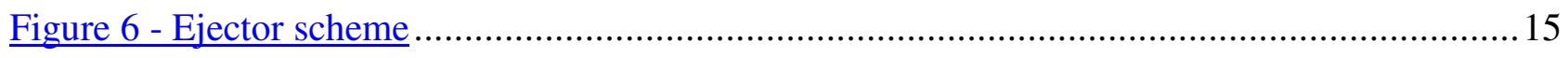

Figure 7 - Schematic sheet describing the iteration step for determining the molar

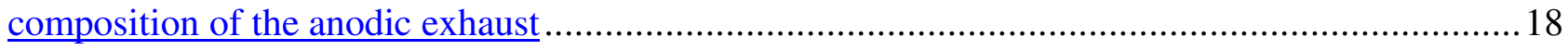

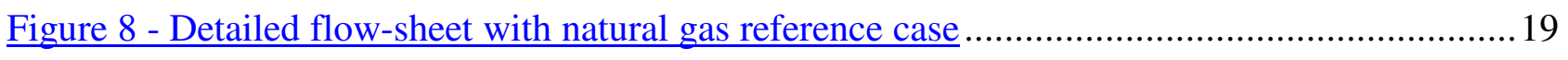

Figure 9 - Detailed flow-sheet with ethanol feeding ..................................................... 20 
Figure 10 - Comparison of the calculated Nernst voltage along the fuel channel (cell tube length) for both natural gas and ethanol feeding.

Figure 11 - Equilibrium compositions of an ethanol/water mixture in a volumetric ratio $\underline{60 / 40 \text { at different temperatures }}$.

Figure 12 - Schematic view of the $5 \mathrm{~kW}$ Generator to respect of the fuel and air feeding flows

Figure 13 - Carbon boundary for the ethanol steam reforming 27

Figure 14 - Ejector pressure increase during EtOH/H2O mixture feeding . 27

Figure 15 - Water stoichiometry in the NG/EtOH mixture reaching the stack ............................228

Figure 16 - Behaviour of stack voltage during the EtOH/H2O feeding experiment ......................28

Figure 17 - Comparison of string voltages during the EtOH/H2O feeding experiment .................29

Figure 18 - Stack voltage and current behaviour ................................................................ 29

Figure 19 - Reformer temperature drop during the ethanol experiment ..................................22

Figure 20 - Temperature behaviour during the ethanol experiment .......................................3 30

Figure 21 - After-burner and stack temperature behaviour ................................................ 31

Figure 22 - Generator electrical AC efficiency behaviour during the EtOH experiment ................31

Figure 1 - Installation of the $5 \mathrm{~kW}$ Siemens Generator in Turbocare Spa ...................................5

Figure 2 - Basic BoP design of the SOFC generator analysed ................................................6

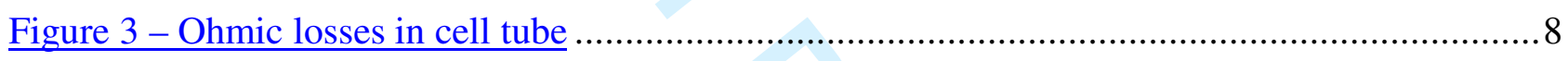

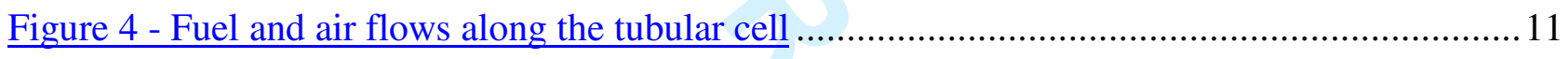

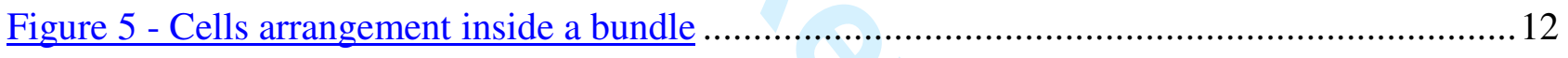

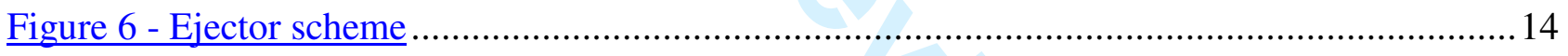

Figure 7 - Schematic sheet describing the iteration step for determining the molar

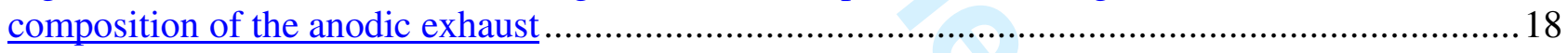

Figure 8 - Detailed flow-sheet with natural gas reference case ............................................ 18

Figure 9 - Detailed flow-sheet with ethanol feeding .................................................... 20

Figure 10 - Comparison of the calculated Nernst voltage along the fuel channel (cell tube length) for both natural gas and ethanol feeding.

Figure 11 - Equilibrium compositions of an ethanol/water mixture in a volumetric ratio $\underline{60 / 40 \text { at different temperatures }}$.

Figure 12 - Schematic view of the $5 \mathrm{~kW}$ Generator to respect of the fuel and air feeding flows

Figure 13 - Carbon boundary for the ethanol steam reforming ...............................................26

Figure 14 - Ejector pressure increase during EtOH/H2O mixture feeding .................................26

Figure 15 - Water stoichs in the NG/EtOH mixture reaching the stack......................................2

Figure 16 - Behaviour of stack voltage during the $\mathrm{EtOH} / \mathrm{H} 2 \mathrm{O}$ feeding experiment ......................227 
Figure 17 - Comparison of string voltage during the $\mathrm{EtOH} / \mathrm{H} 2 \mathrm{O}$ feeding experiment......................2 28

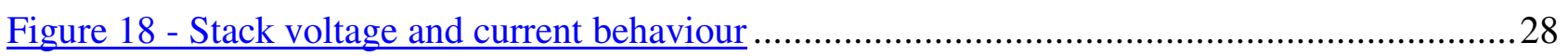

Figure 19 - Reformer temperature drop during the ethanol experiment ………….........................2 29

Figure 20 - Temperature behaviour during the ethanol experiment ……………….........................29

Figure 21 - After-burner and stack temperature behaviour ....................................................... 30

Figure 22 - Generator electrical AC efficiency behaviour during the EtOH experiment ..................30 
Table 1. Molar compositions of the recirculated flow entrained by the ejector and total steam fraction recirculated normalized to the primary flow entering the ejector itself

\begin{tabular}{|c|c|c|c|}
\hline \multicolumn{3}{|c|}{ Ejector volumetric entrainment ratio 'NG feeding': } & \multirow[t]{2}{*}{5.53} \\
\hline \multicolumn{3}{|c|}{ Anodic molar exhaust composition: } & \\
\hline $\mathrm{H}_{2}[\%]$ & $\mathrm{CO}[\%]$ & $\mathrm{H}_{2} \mathrm{O}[\%]$ & \multirow{3}{*}{$\begin{array}{c}\mathrm{CO}_{2}[\%] \\
28\end{array}$} \\
\hline 16 & 4 & 52 & \\
\hline $\mathrm{Mol}\left(\mathrm{H}_{2} \mathrm{O}\right) / \mathrm{M}$ & & 2.9 & \\
\hline
\end{tabular}

Ejector volumetric entrainment ratio 'EtOH feeding': $\quad 5.39$

Anodic molar exhaust composition:

$\begin{array}{cccc}\mathrm{H}_{2}[\%] & \mathrm{CO}[\%] & \mathrm{H}_{2} \mathrm{O}[\%] & \mathrm{CO}_{2}[\%] \\ 5 & 13 & 56 & 26\end{array}$

$\mathrm{Mol}\left(\mathrm{H}_{2} \mathrm{O}\right) / \mathrm{Mol}($ fuel_in):

3.0 
Tubular Cell - Model Parameters

Cathode inner diameter / mm 21.7

Mean tube diameter / $\mathrm{mm}$

Cathode thickness / $\mu \mathrm{m}$

Electrolyte thickness / $\mu \mathrm{m}$

40

Anode thickness / $\mu \mathrm{m}$

100

Interconnector thickness / $\mu \mathrm{m}$

100

Interconnector width / cm

1.3

$\mathrm{Ni}$-felt thickness / $\mathrm{cm}$

0.5

Tubular cell length $/ \mathrm{cm}$

75

Cell active area $/ \mathrm{cm}^{2}$

400

\begin{tabular}{|c|c|}
\hline$\rho_{\text {el,cat }} / \Omega \mathrm{m}$ & $0.008114 \times \exp (500 / \mathrm{T})$ \\
\hline$\rho_{\text {elely }} / \Omega \mathrm{m}$ & $0.00294 \times \exp (10350 / \mathrm{T})$ \\
\hline$\rho_{e l, a n} / \Omega \mathrm{m}$ & $0.00298 \times \exp (-1392 / \mathrm{T})$ \\
\hline$\rho_{\text {el,inter }} / \Omega \mathrm{m}$ & $0.1256 \times \exp (4690 / \mathrm{T})$ \\
\hline$\rho_{\text {el,felt }} / \Omega \mathrm{m}$ & - \\
\hline$\gamma_{a n} / \mathrm{A} \mathrm{m}^{-2}$ & $7 \times 10^{8}$ \\
\hline$\gamma_{c a t} / \mathrm{A} \mathrm{m}^{-2}$ & $5.5 \times 10^{8}$ \\
\hline$E_{a c t, a n} / \mathrm{kJ} \mathrm{mol}^{-1}$ & 100 \\
\hline$E_{\text {act,cat }} / \mathrm{kJ} \mathrm{mol}^{-1}$ & 120 \\
\hline$\varepsilon_{a n}($ anode porosity) & 0.3 \\
\hline$\tau_{a n}$ (anode tortuosity) & 5 \\
\hline$\varepsilon_{c a t}($ cathode porosity) & 0.4 \\
\hline$\tau_{\text {cat }}$ (cathode tortuosity) & 4 \\
\hline$r_{p o r e, a n}($ mean cathode pores radius) & 3 \\
\hline$r_{p o r e, c a t}($ mean cathode pores radius) & 15 \\
\hline
\end{tabular}

Table 2 - Parameters for the cell electrochemical model 


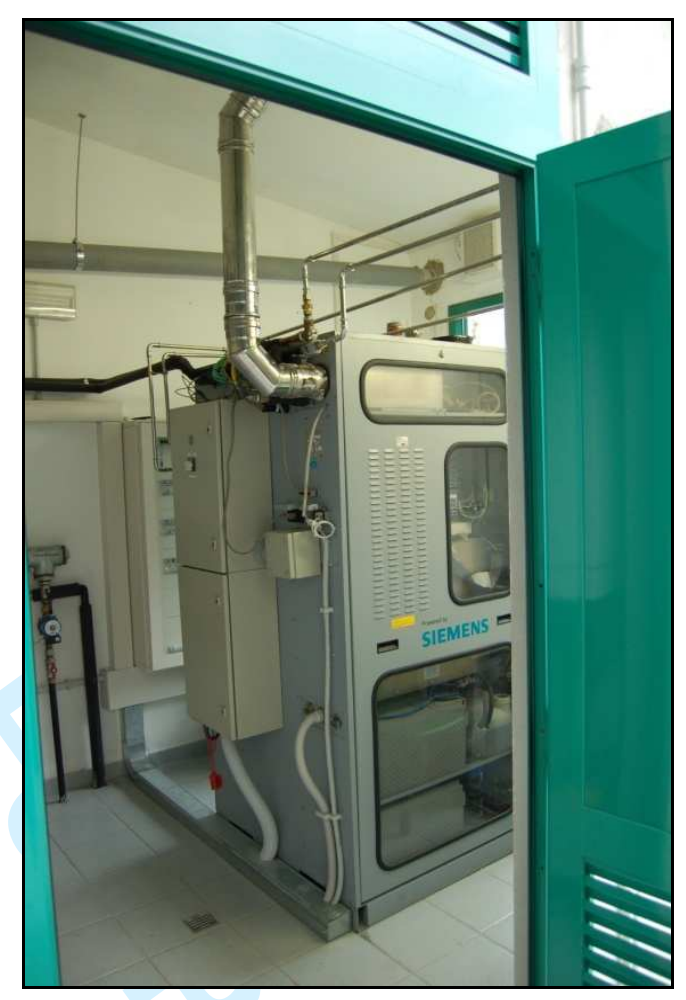

Figure 1. Installation of the $5 \mathrm{~kW}$ Siemens Generator in Turbocare Spa. 


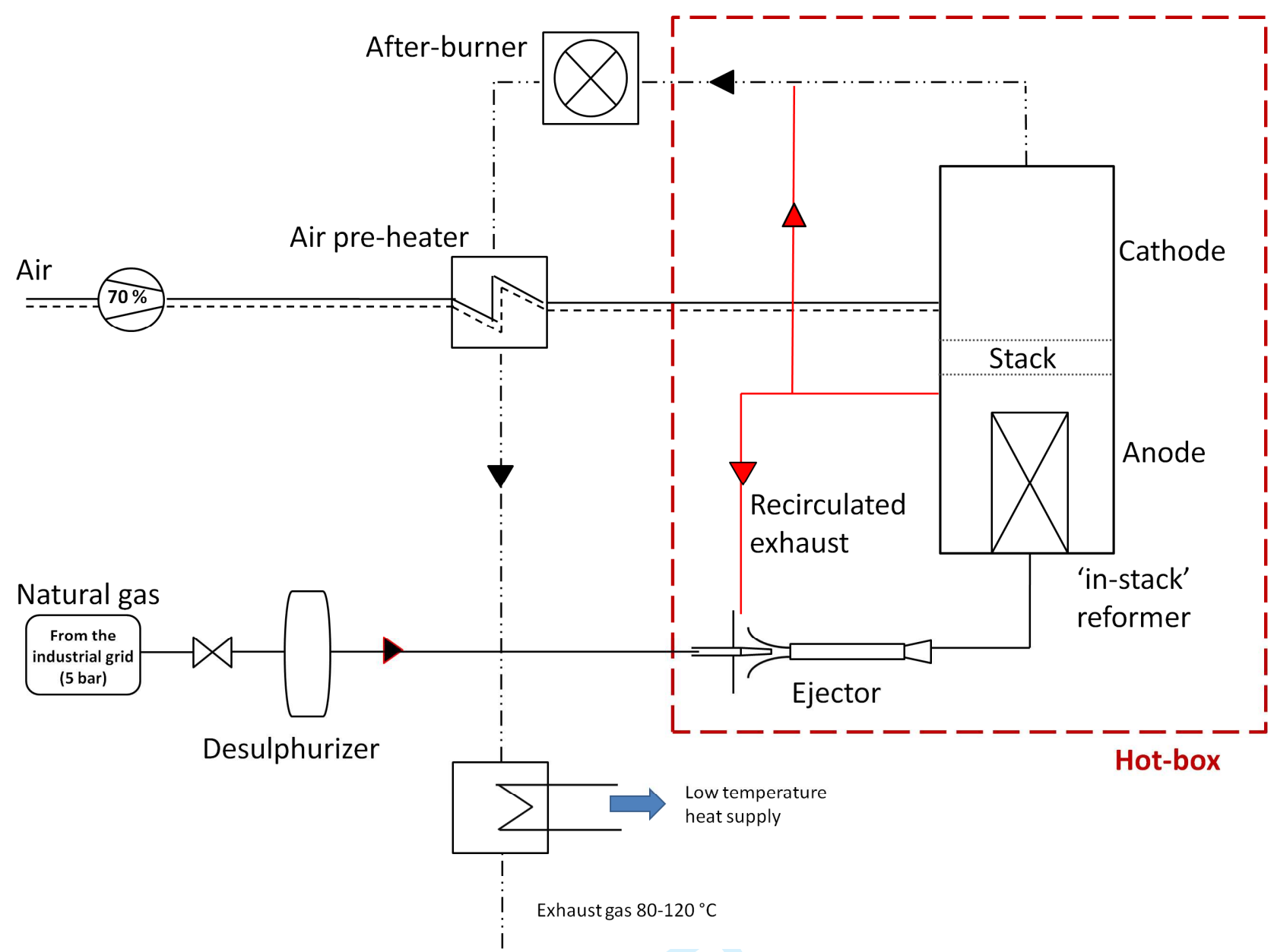

Figure 2. Basic BoP design of the SOFC generator analyzed 


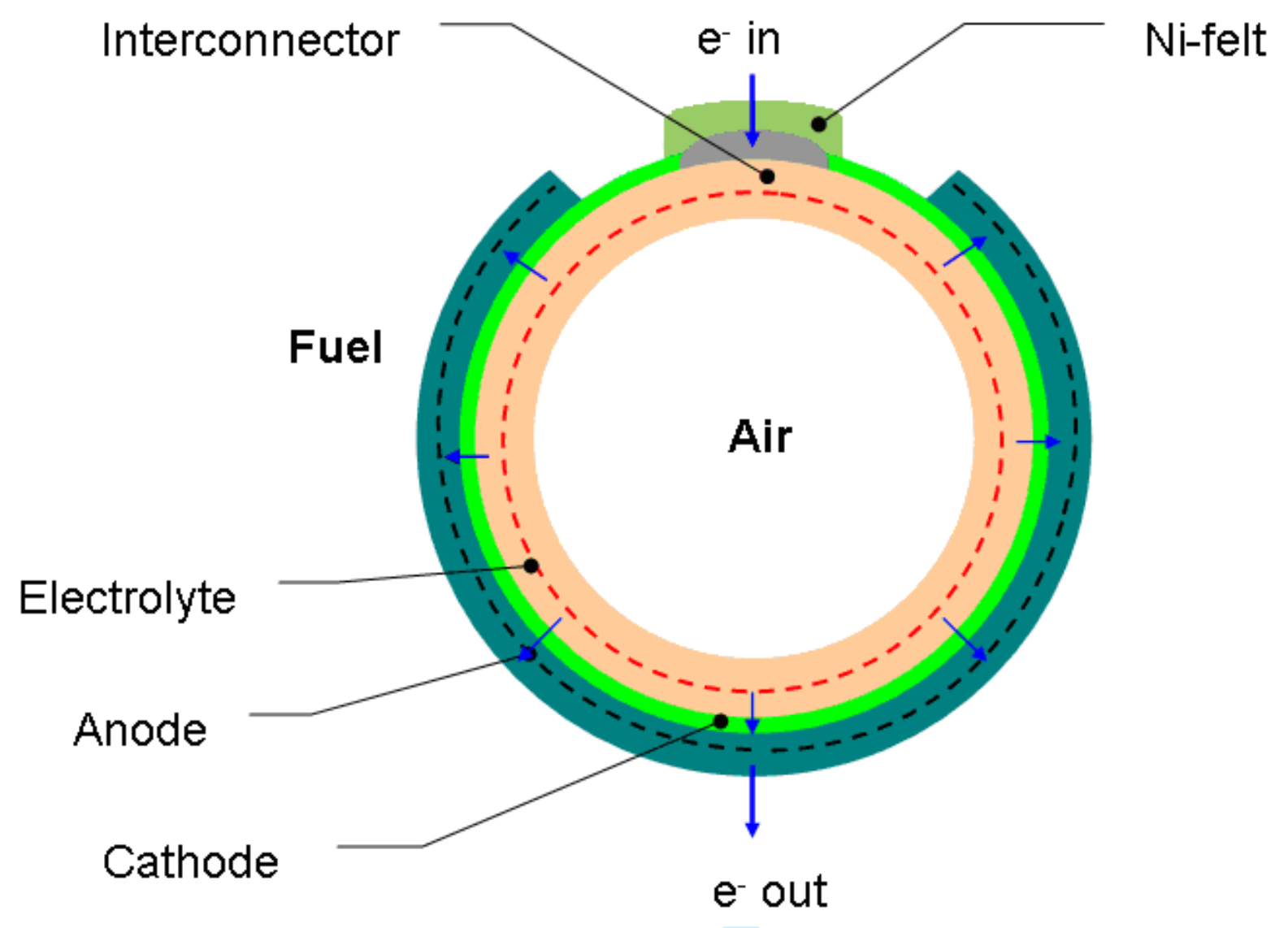

Figure 3 - Ohmic losses in the tubular cell 
Feeding air tube

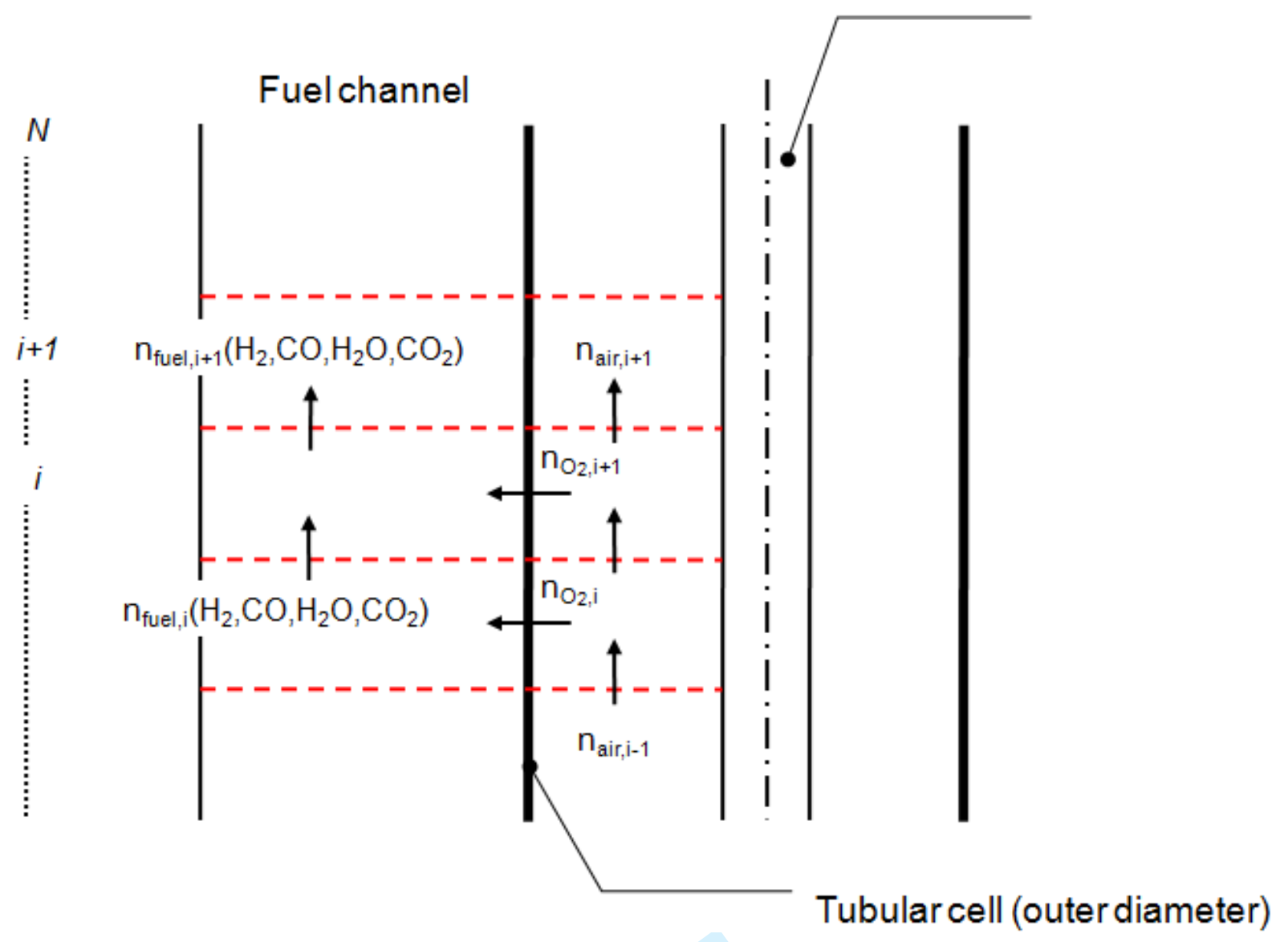

Figure 4 - Fuel and air flows along the tubular cell 

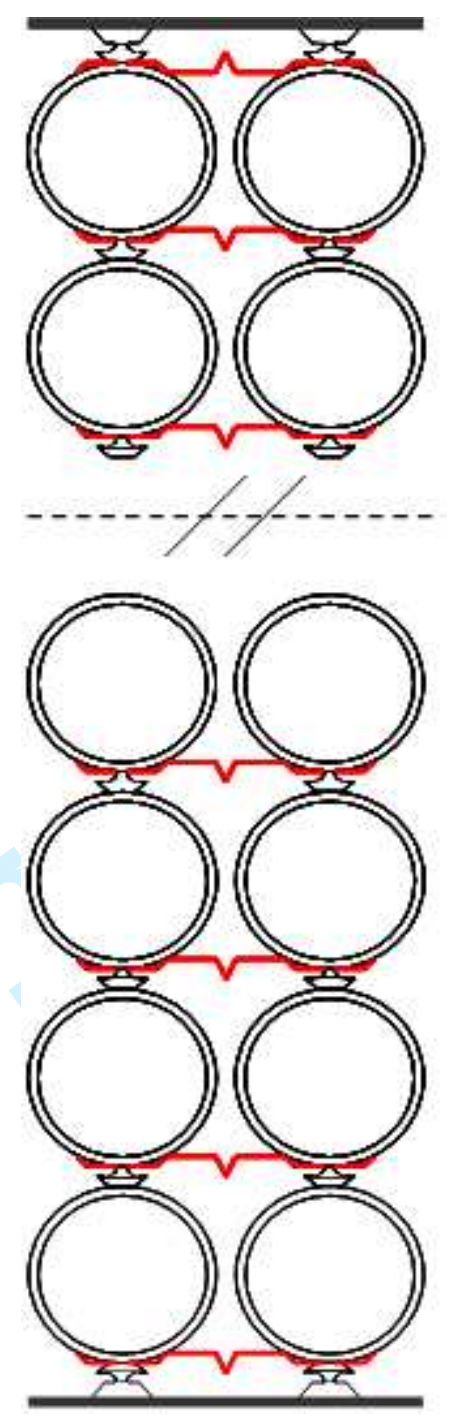

Figure 5 - Cells arrangement inside a bundle 
Page 75 of 90

Fuel Cells

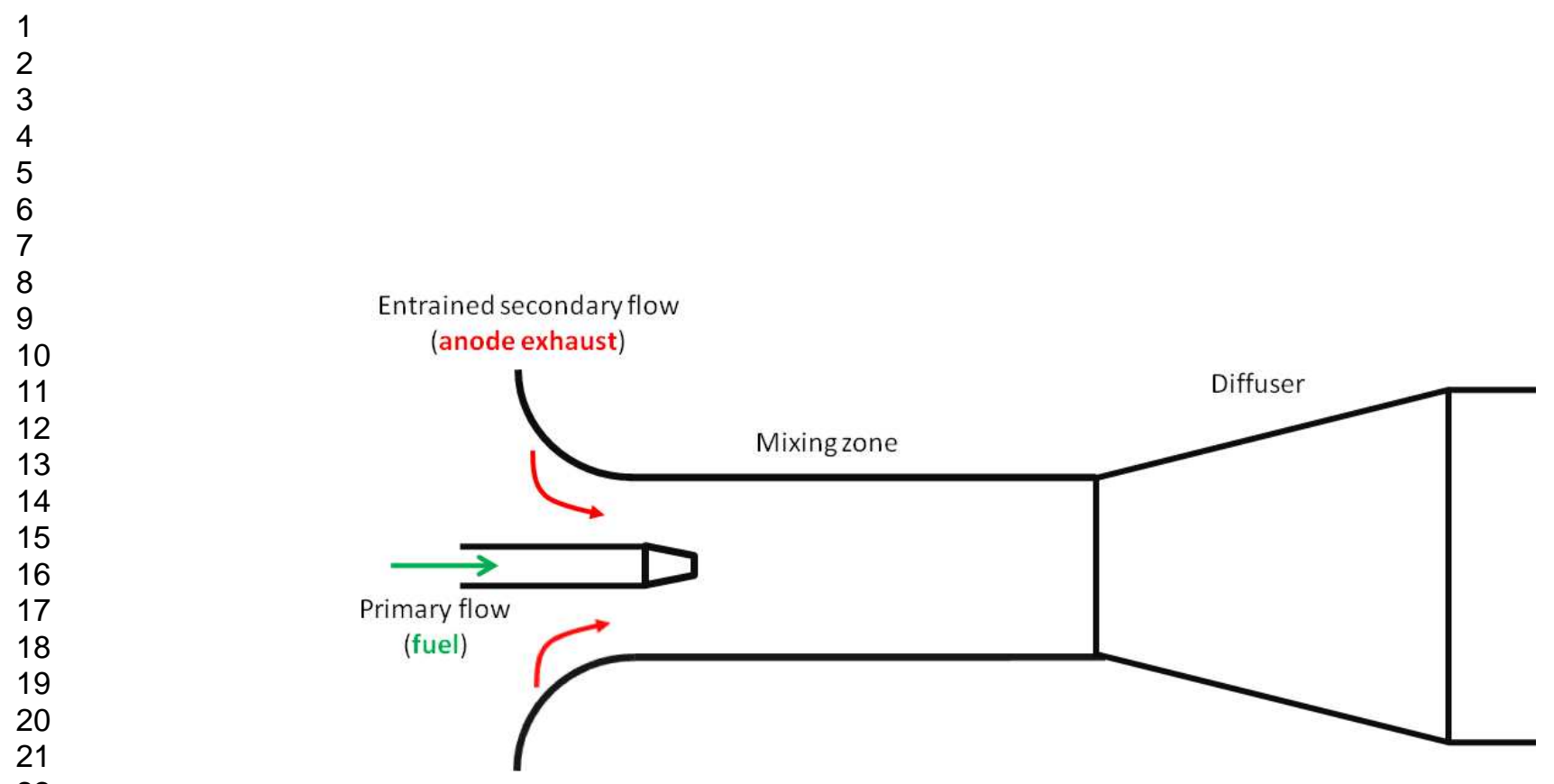

Figure 6. Ejector scheme $254 \times 190 \mathrm{~mm}(96 \times 96 \mathrm{DPI})$

Wiley-VCH 


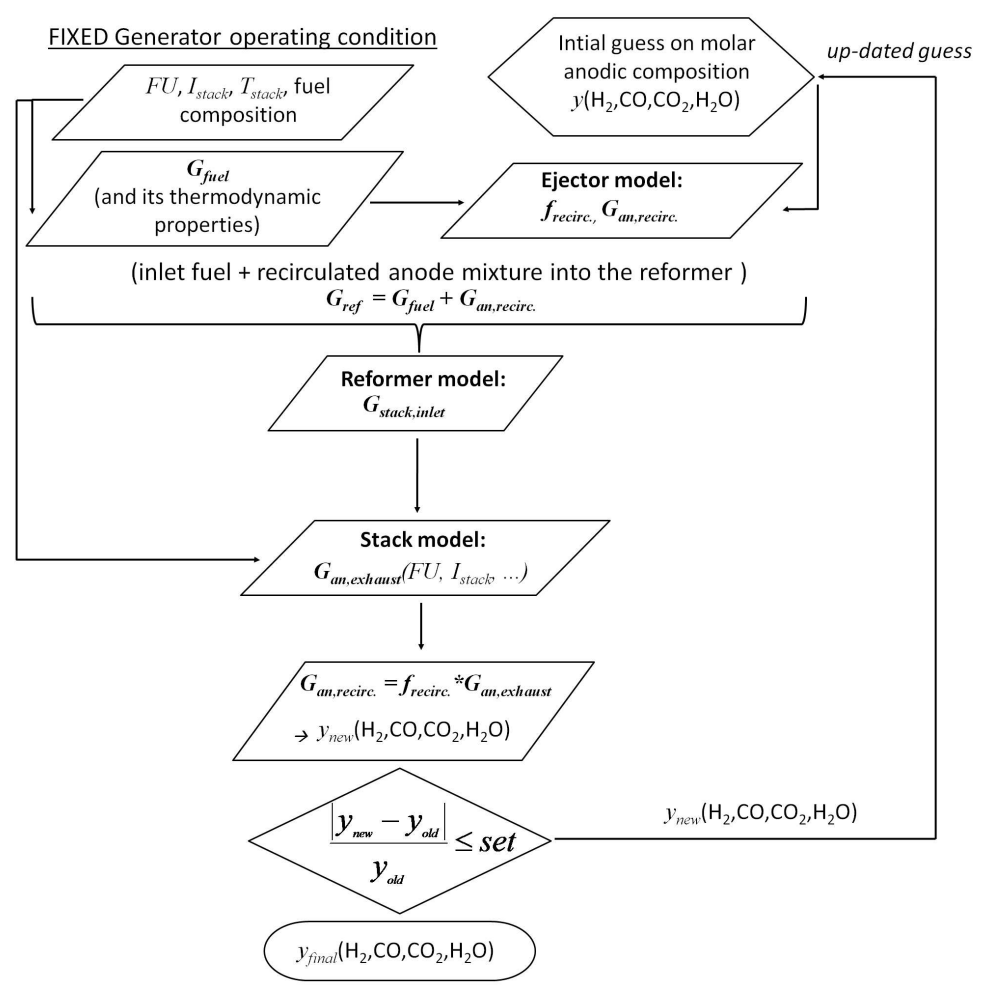

Figure 7. Schematic sheet describing the iteration step for determining the molar composition of the anodic exhaust $701 \times 533 \mathrm{~mm}(96 \times 96 \mathrm{DPI})$ 


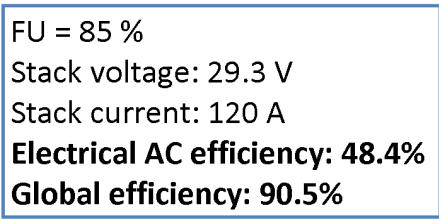

Figure 8. Detailed flow-sheet with natural gas (reference case) 


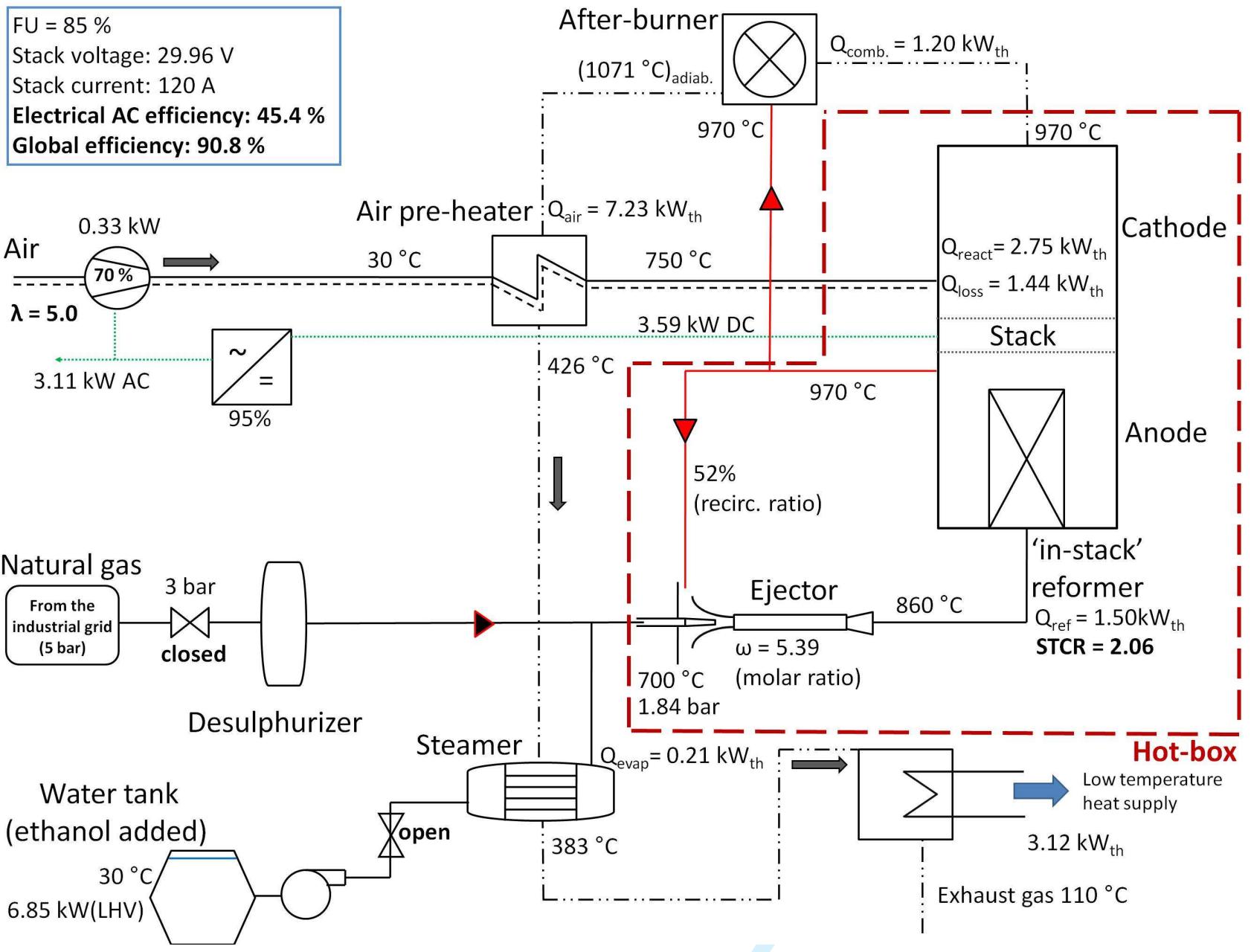

Figure 9. Detailed flow-sheet with ethanol feeding 


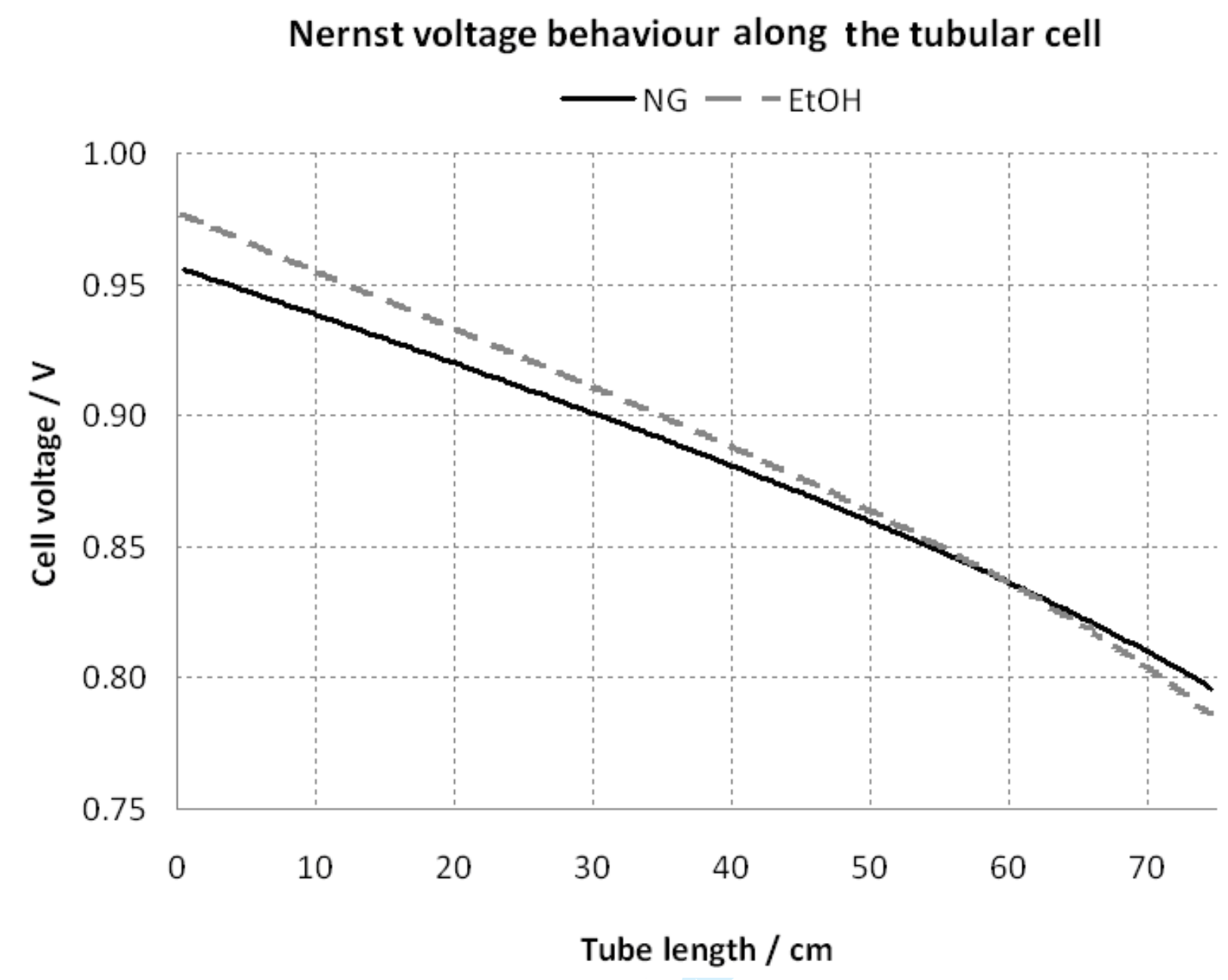

Figure 10. Comparison of the calculated Nernst voltage along the fuel channel (cell tube length) for both natural gas and ethanol feeding 


\section{Equilibrium compositions for EtOH/H2O mixture @ 33/67 vol. ratio}

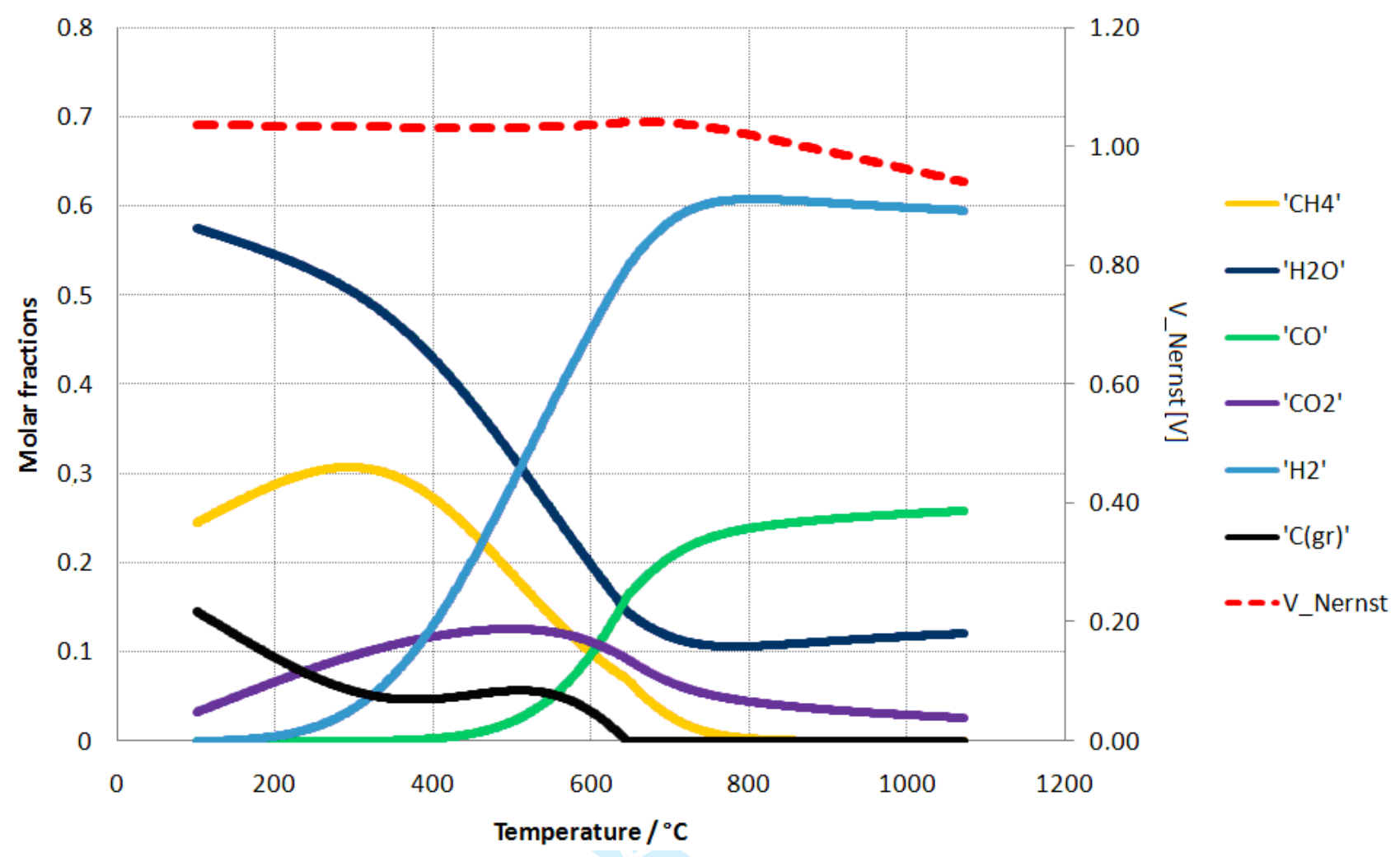

Figure 11. Equilibrium compositions of an ethanol/water mixture in a volumetric ratio 60/40 at different temperatures 

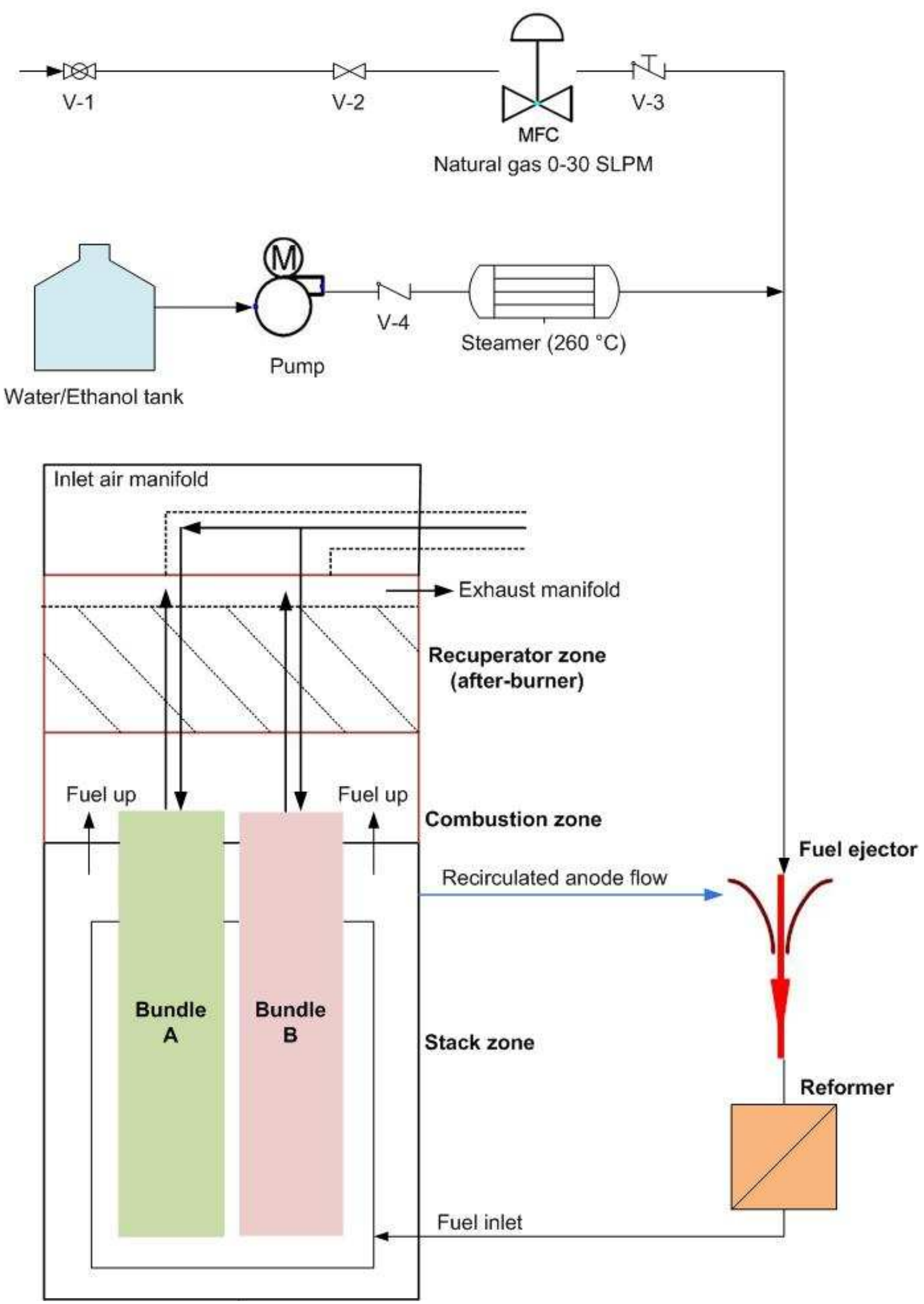

Figure 12. Schematic view of the $5 \mathrm{~kW}$ Generator to respect of the fuel and air feeding flows 


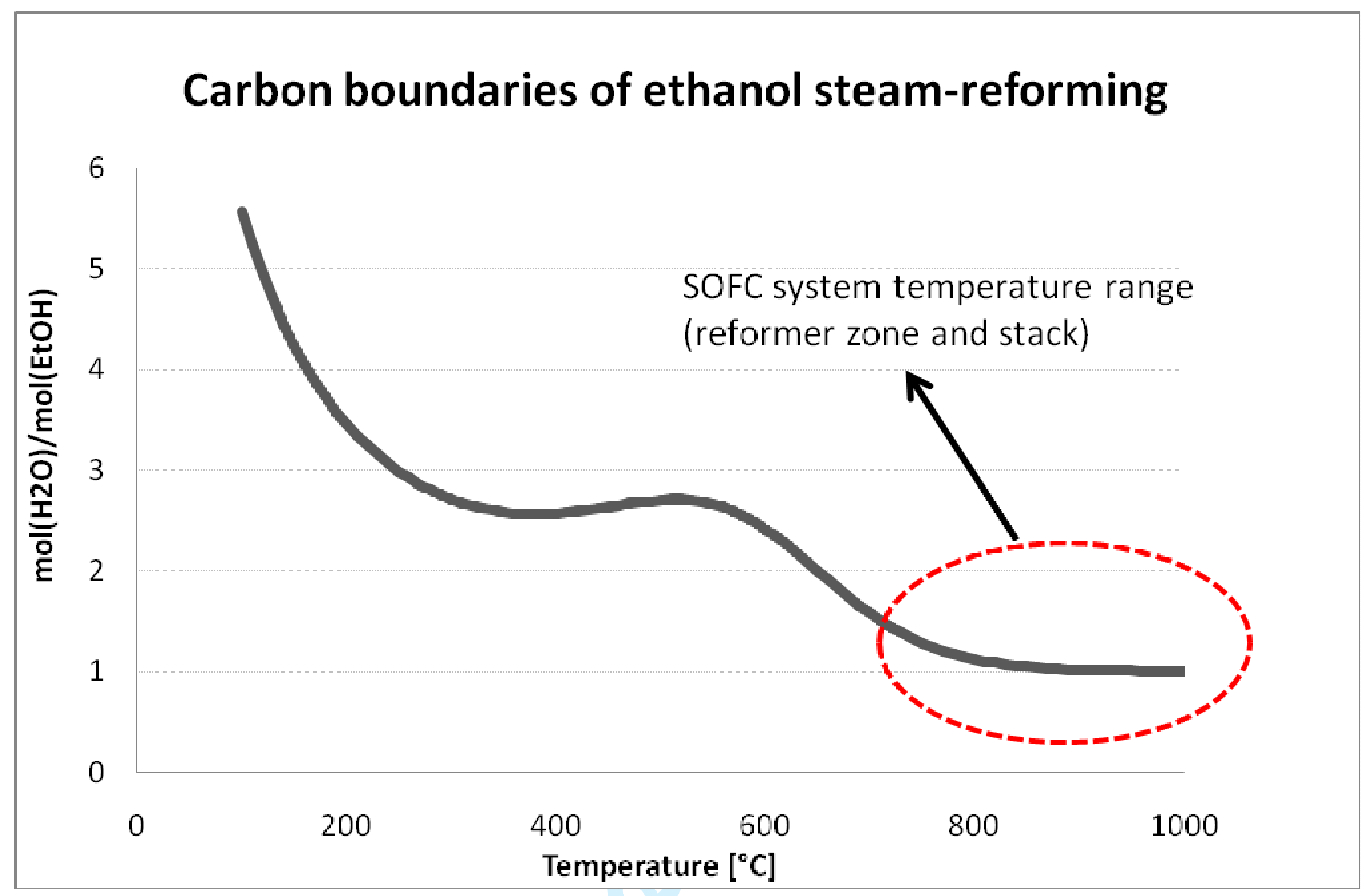

Figure 13. Carbon boundary for the ethanol steam-reforming 


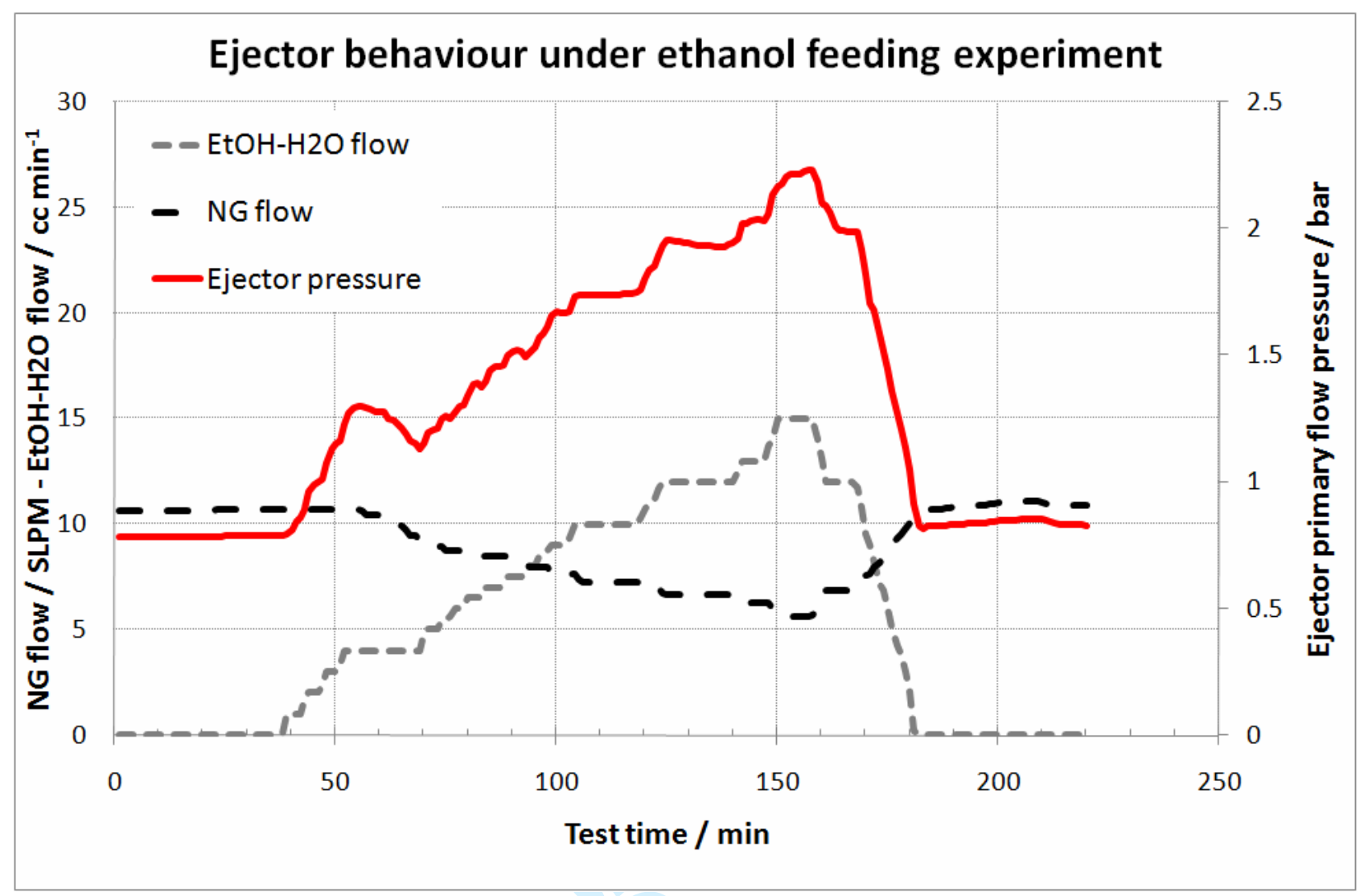

Figure 14. Ejector pressure increase during EtOH/H2O mixture feeding 


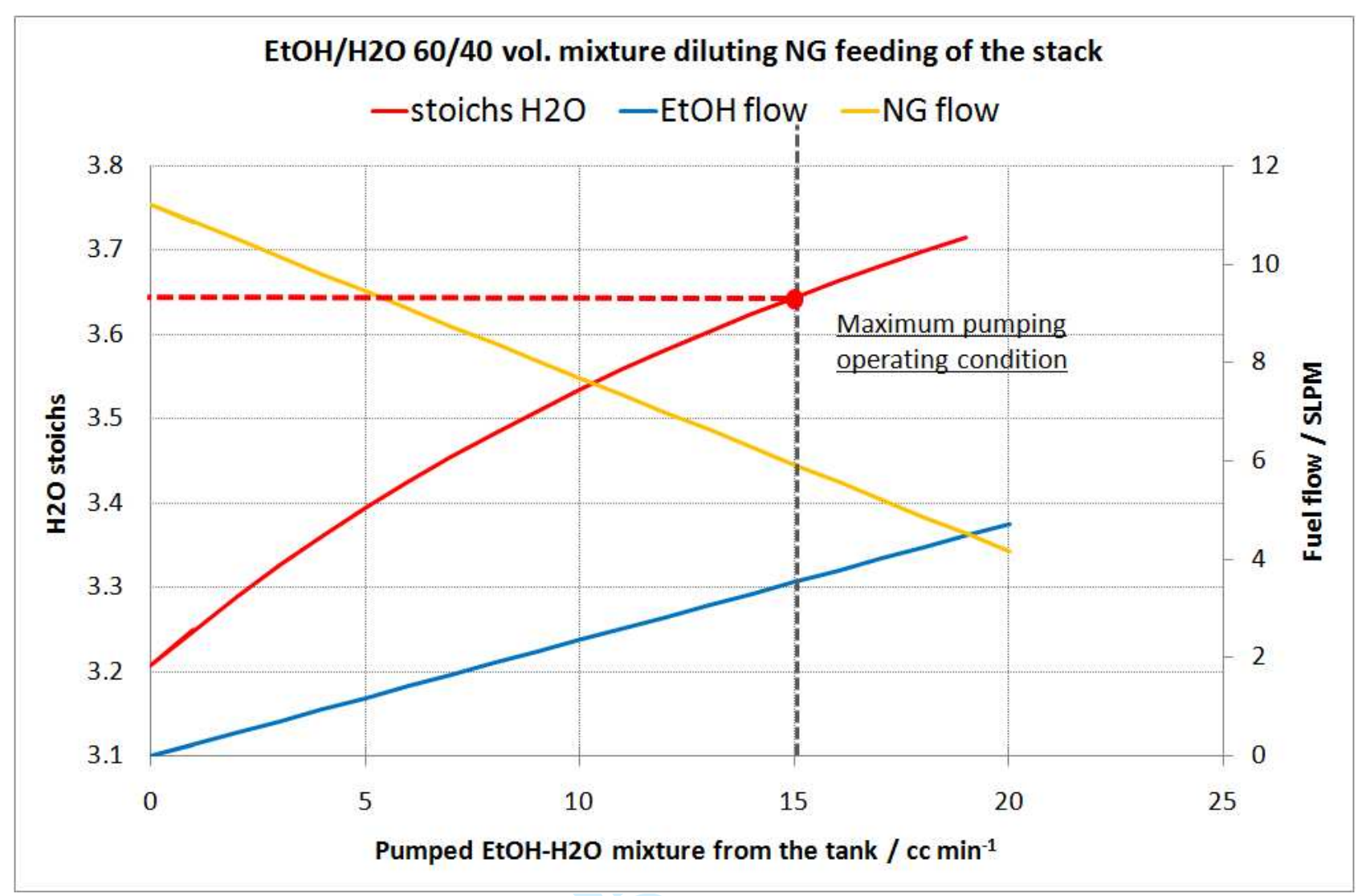

Figure 15. Water stoichiometry in the $\mathrm{NG} / \mathrm{EtOH}$ mixture reaching the stack 


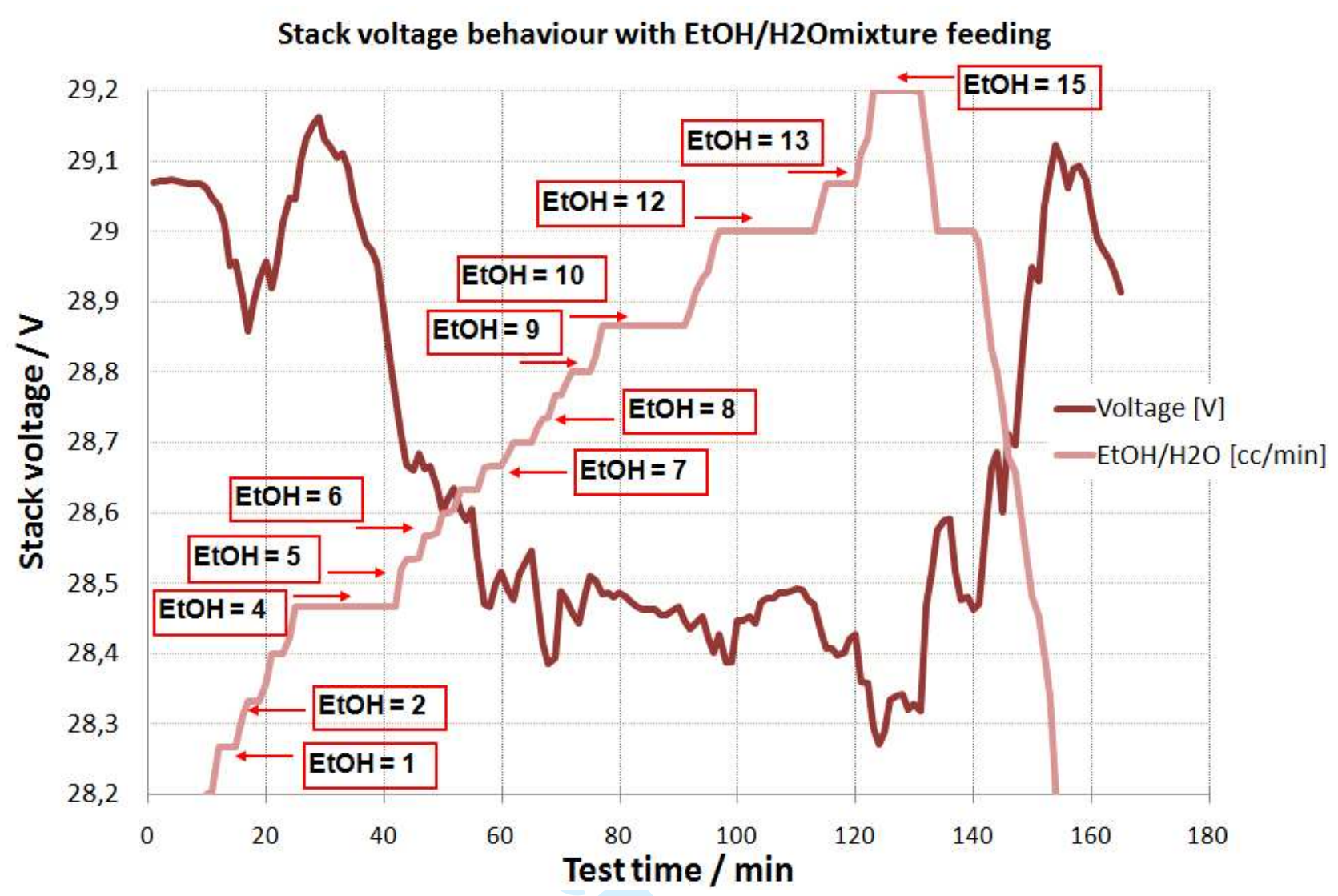

Figure 16. Behaviour of stack voltage during the EtOH/H2O feeding experiment 


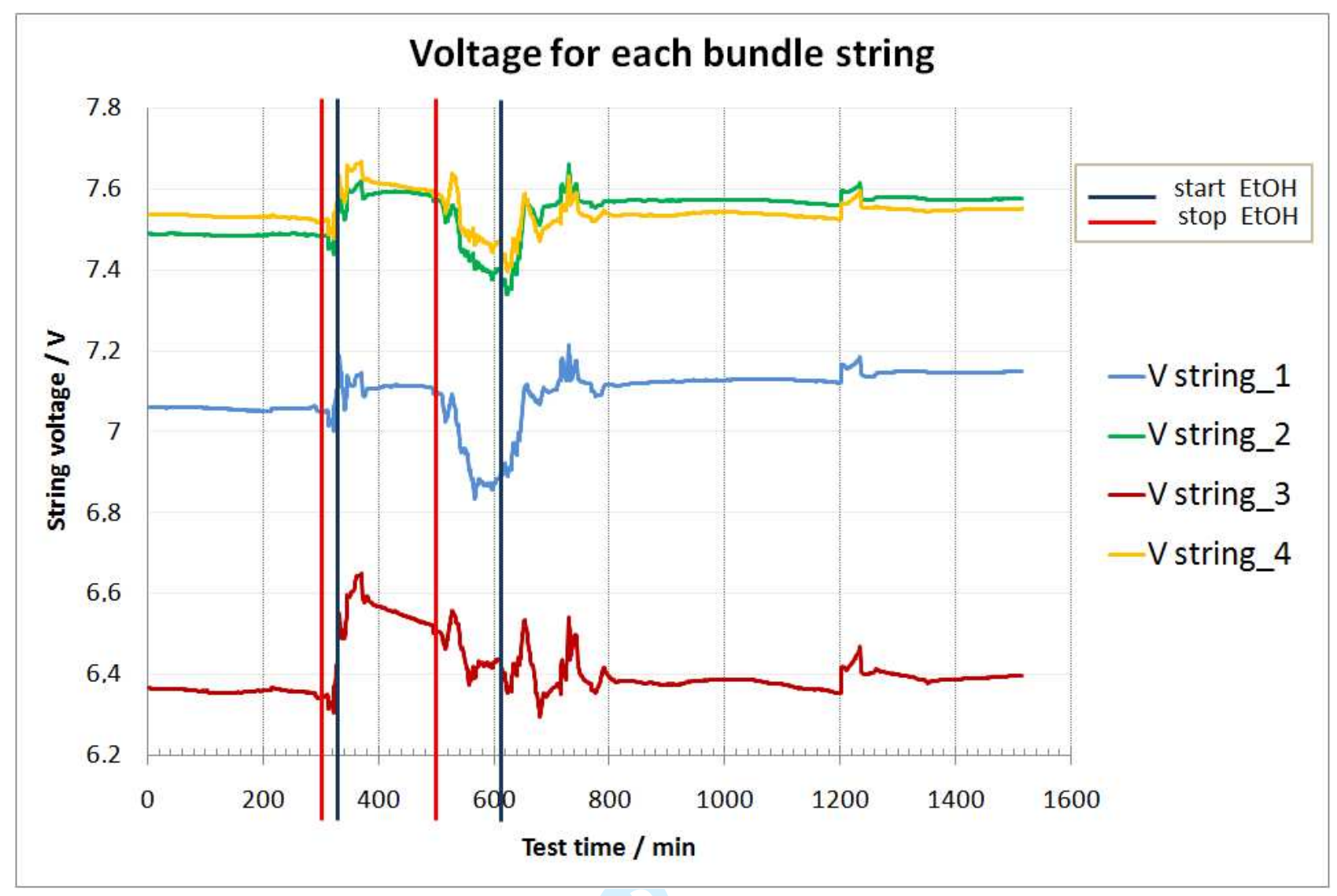

Figure 17. Comparison of string voltage during the EtOH/H2O feeding experiment 


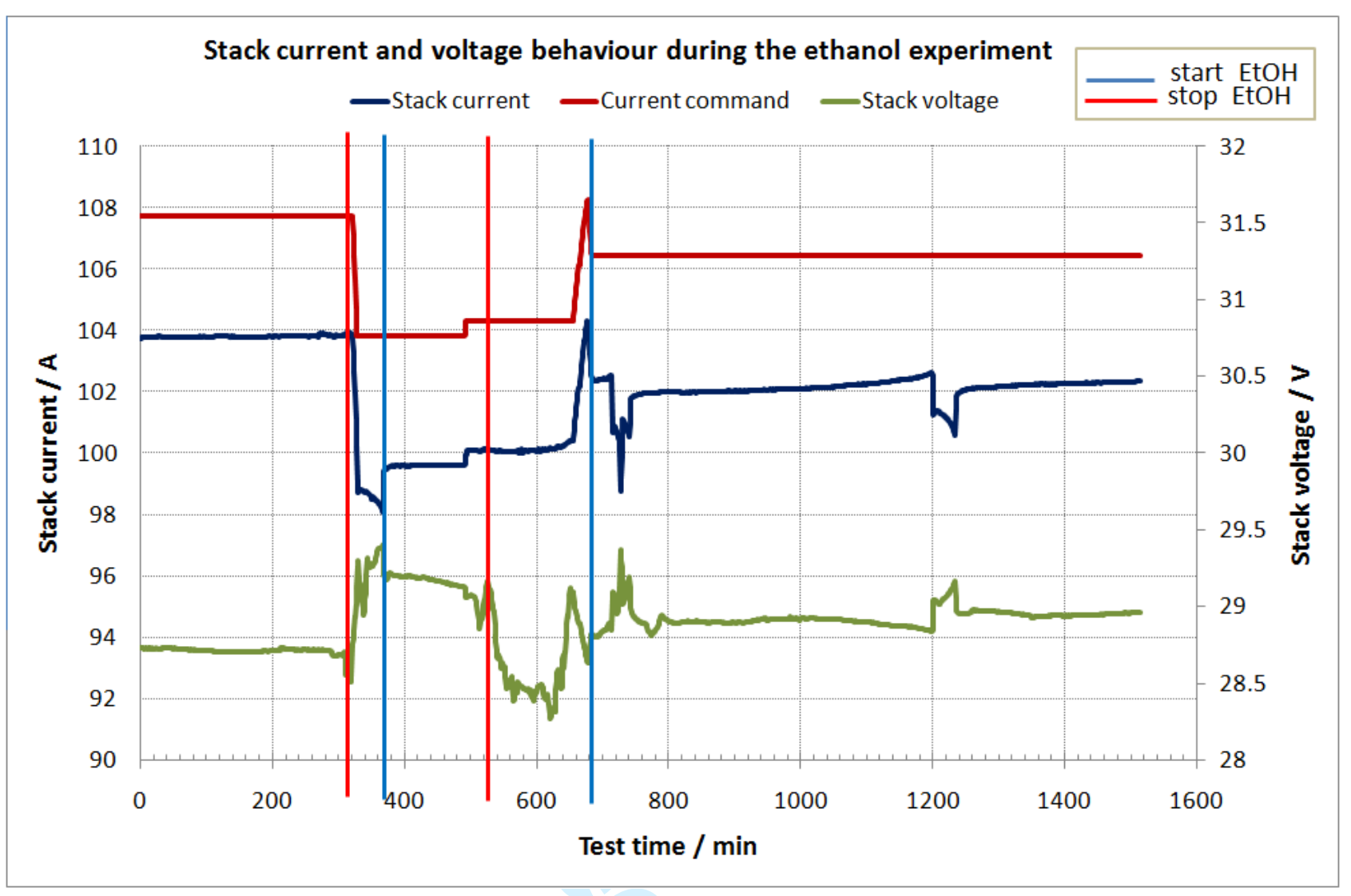

Figure 18. Stack voltage and current behaviour during the EtOH experiment 


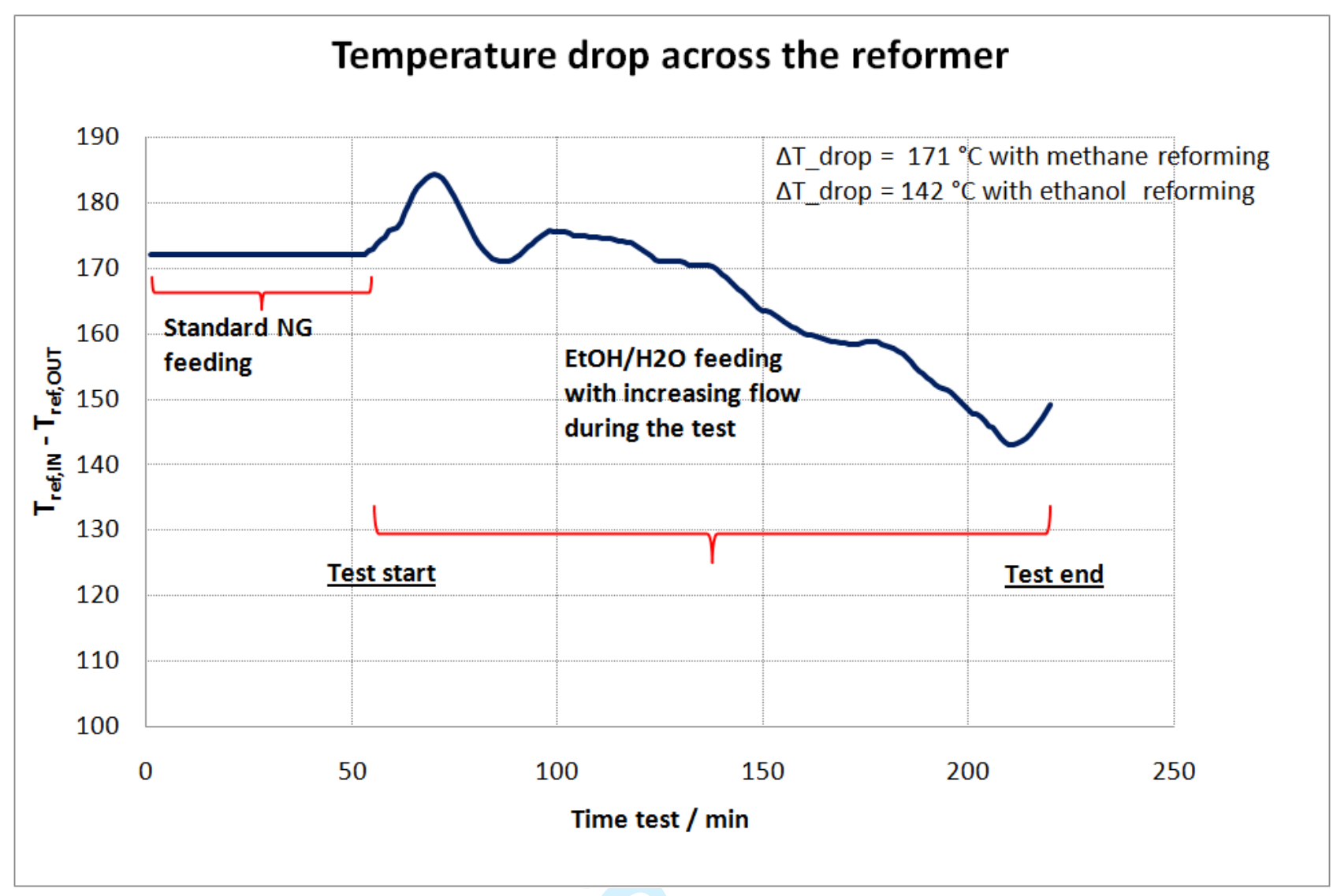

Figure 19. Reformer temperature drop during the ethanol experiment 


\section{Temperatures behaviour inside the stack due to EtOH feeding}

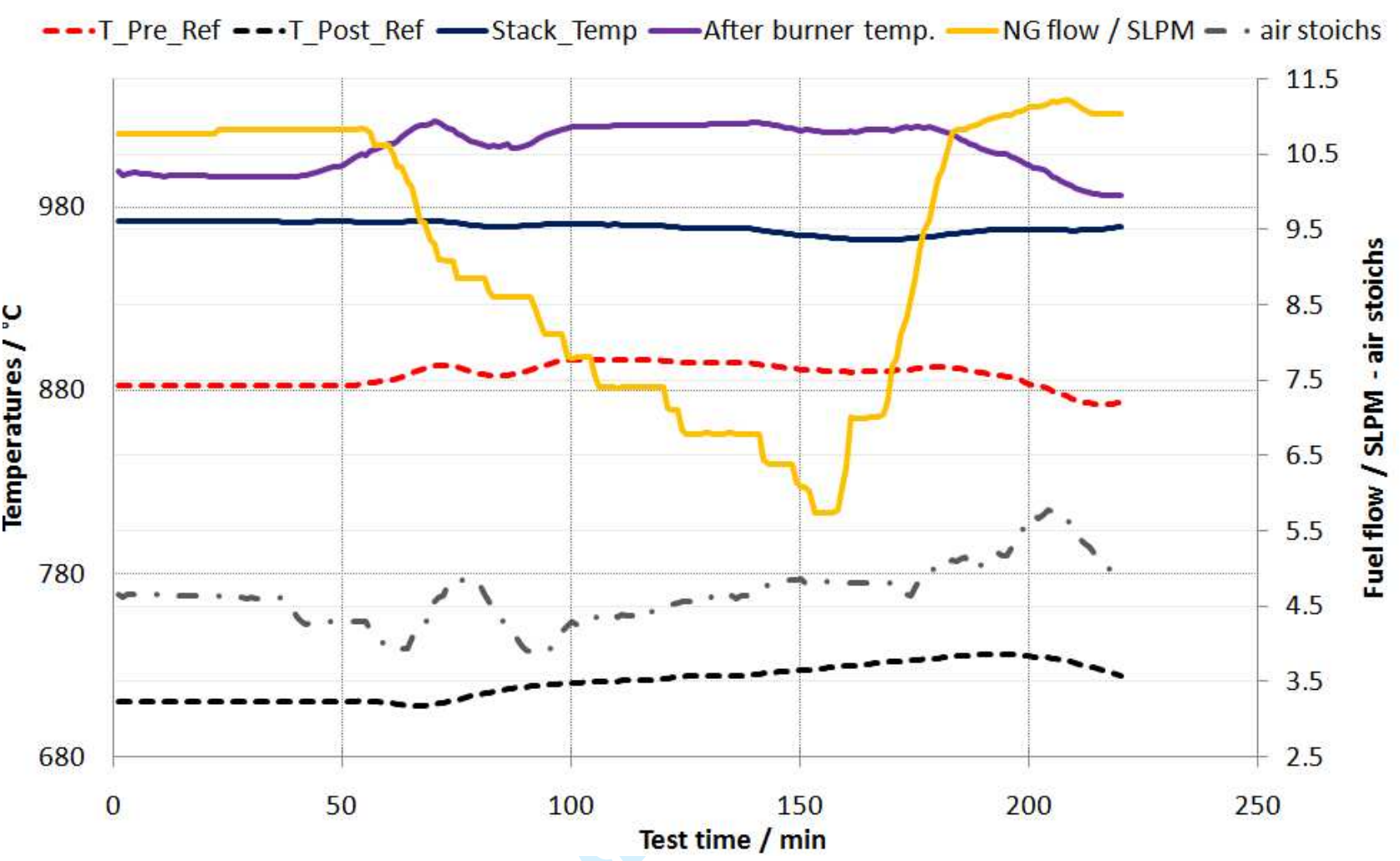

Figure 20. Generator temperatures behaviour during the ethanol experiment 


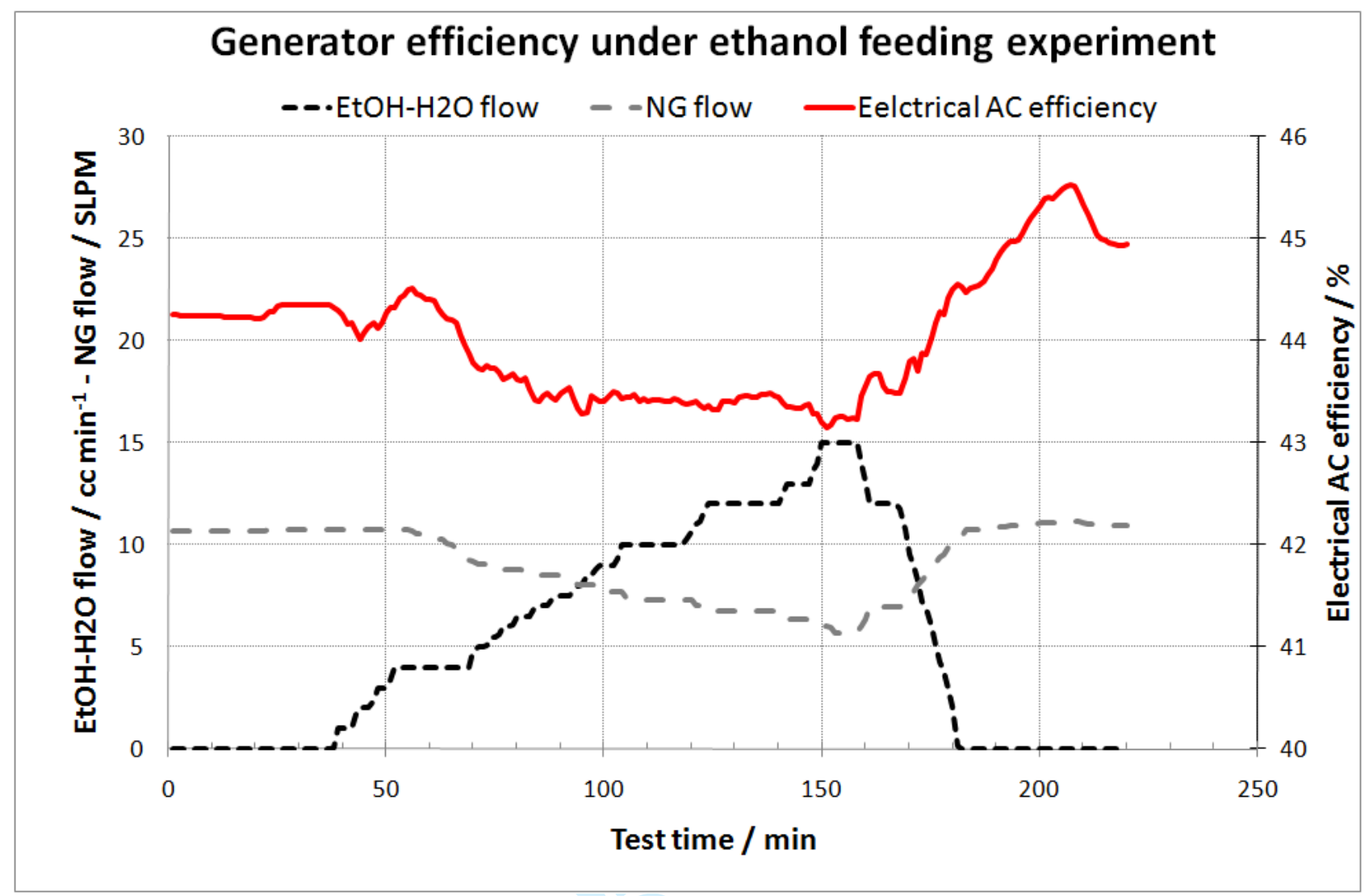

Figure 21. Generator electrical AC efficiency behaviour during the EtOH experiment 